Linköping Studies in Science and Technology,

Dissertations No. 1892

\title{
Production Strategy in Project Based Production within a House-Building Context
}

Henric Jonsson

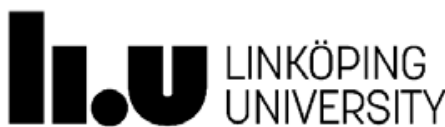


Production Strategy in Project Based Manufacturing Within a House-Building Context

Henric Jonsson

Linköping Studies in Science and Technology, Dissertations, No. 1892

Copyright $($ ), Henric Jonsson, 2018, unless otherwise noted

ISBN 978-91-7685-401-3

ISSN 0345-7524

Linköping University

Department of Science and Technology

SE-601 74 Norrköping, Sweden

Printed in Sweden by LiU-Tryck, Linköping, Sweden, 2017 


\section{Abstract}

A production strategy enables companies to effectively manage the different challenges that the production function face in a competitive environment. A production strategy helps a company to make operational and strategic decisions that follow a logical pattern and supports the corporate strategy and the competitive priorities of the company. When no strategy exists the decisions may be arbitrary and unpredictable leading to an underachieving production system. Production strategy involves decisions that shape the long term capabilities of a producing company. For the traditional production industry there are a number of production strategy frameworks that facilitates the process of designing production systems. However, these frameworks typically leave project based production out of the scope or treat project based production as one type of production system, when in fact project based production systems can be multifaceted depending on product design and market requirements.

This thesis focus on project based manufacturing in a house-building context. Houses can be produced by different types of production systems, and depending on how the production systems are designed they have strengths and weaknesses in different areas of competition. To be able to meet the increasing demand for residential houses, and improve performance in the house-building industry, the way houses are produced have to match different market requirements in a more effective and efficient way. To do this a production strategy has to exist. Typically there is a trade-off between productivity and flexibility, hence a production system designed to meet customer requirements concerning product design is probably not the best process choice if the customer thinks price and delivery time are the most important. A production strategy helps a company to make decisions so that the output of the production system meets customer requirements in the best possible way. Due to the fact that project based production is typically left out of the scope in traditional production strategy literature and that there is a lack of research concerning production strategy in a house-building context, the purpose of this research is:

... to extend the production strategy body of knowledge concerning project based production in a house-building context.

To fulfil the purpose the following four research questions are studied and answered:

RQ1: What aspects can be useful in a classification matrix contrasting different production systems for house-building?

RQ2: Which competitive priorities are important to measure when evaluating different production systems on a production strategy level in a house-building context, and how can they quantitatively be measured? 
RQ3: How does the characteristics of the production system, i.e. the process choice, affect information exchange in a house-building context?

RQ4: How can a new production strategy be formulated and implemented in an industrialised house-building context and what challenges are important to consider in that process?

To answer RQ1 a classification matrix was developed that classify production systems along two dimensions: a product dimension (degree of product standardisation) and a process dimension (degree of off-site assembly). The two dimensions are related, for example a high degree of standardisation should be matched with a high degree of off-site assembly and consequently a low degree of product standardisation should be matched with a low degree of off-suite assembly. A mismatch, e.g. high degree of off-site assembly and low degree of standardisation, typically leads to poor performance and should hence be avoided.

To be able to see how different types of production systems perform in different areas of competition key performance indicators (KPIs) were developed. The KPIs presented in this research can be used to measure quality, delivery (speed and dependability), cost (level and dependability), and flexibility (volume and mix) at a production strategic level (RQ2).

Furthermore, to answer RQ3, a production strategy perspective was taken on information exchange by relating information exchange to the design of the production system. The results indicate that employing different types of production systems leads to different approaches to information exchange. Employing a production systems using traditional production methods on-site and a low degree of product standardisation lead to a traditional approach to information exchange, e.g. project meetings, telephone and mail. Production systems employing some degree of off-site assembly have less complex and more stable supply chains and use ICT-solutions to a higher extent, which facilitates information exchange. The findings also indicate that a high degree of product standardisation facilitates the use of ICT-solutions such as ERP and BIM.

RQ4 concerns the production strategy process, i.e. formulation and implementation. Failure in this processes can jeopardise the whole business. Based on a longitudinal case study of an industrialised house-builder a suggested production strategy process was developed, including both production strategy formulation and implementation. The study also identified context specific challenges that have to be considered in an industrialised housebuilding context, e.g. the complexity that comes with using two different production processes (off-site and on-site) in the same production system.

The research is case based and a total number of eight different production systems have been studied. Data has been collected through interviews, observations, and review of company documents. 


\section{Populärvetenskaplig sammanfattning}

I juni 2016 kom Boverket ut med en prognos över behovet av nya bostäder till år 2025 . Enligt den rapporten råder det idag brist på bostäder i majoriteten av Sveriges kommuner och för att komma till rätta med det bedömer man att det kommer att behöva byggas 700000 nya bostäder fram till år 2025. Det innebär att man behöver bygga omkring 88000 nya bostäder per år. Som en jämförelse färdigställdes knappt 127700 bostäder under perioden 2012-2015. Byggbranschen står alltså inför en stor utmaning om man ska lyckas tillgodose behovet av nya bostäder.

I denna avhandling är produktionsstrategi inom husbyggnation i fokus. Produktionsstrategi handlar om att ta beslut om hur företagets produktionssystem ska utformas så att det möter kraven från företagets kunder på bästa sätt. Avhandlingen kategoriserar och jämför olika typer av produktionssystem för husbyggnation, exempelvis olika industriella produktionssystem med förtillverkning $\mathrm{i}$ en fabrik och traditionell produktion på byggarbetsplatsen. Avhandlingen beskriver och utvärderar också själva processen att rent praktiskt formulera och implementera en produktionsstrategi. Ur ett praktiskt perspektiv bidrar forskningen till att hjälpa byggföretag att utforma sitt produktionssystem så att de på ett så effektivt sätt som möjligt kan tillgodose kraven från valt kundsegment. Tanken med denna forskning är alltså att underlätta för byggföretag i deras arbete med produktionsstrategi så att rätt typ av produktionssystem används för att bygga rätt typ av hus. Om man gör det kommer husbyggnationen bli effektivare, vilket är en förutsättning om dagens och framtidens efterfrågan på bostäder ska kunna tillgodoses.

För att på ett effektivt sätt kunna möta kraven från marknaden måste det finnas en koppling mellan marknaden och företagets produktionsfunktion. Om kunden exempelvis efterfrågar ett billigt hus och kort leveranstid måste produktionssystemet vara utformat för att minimera produktionskostnad och ledtid. Tycker kunden däremot att kundanpassning och produktdesign är viktigt så måste produktionssystemet vara flexibelt. Detta kan låta enkelt och logiskt, men i praktiken kan det vara svårt att se kopplingen mellan olika konkurrensfaktorer på marknaden (kostnad, kvalitet, leveranstid, flexibilitet) och de olika beslut som måste tas för att utforma sitt produktionssystem (personal, organisationsstruktur, materialförsörjning, val av produktionsprocess etc.) så att de möter kundkraven på ett effektivt sätt. Denna avhandling kan hjälpa byggföretag att lyckas med detta, vilket förhoppningsvis leder till att kundernas behov tillgodoses, vilket i sin tur ger nöjda kunder samtidigt som verksamheten blir effektiv och lönsam.

Avhandlingen består av tre studier. I den första studien presenteras ett verktyg för att kunna kategorisera och jämföra olika typer av produktionssystem för produktion av flerbostadshus. Kopplat till det har nyckeltal (KPIer) tagits fram så man kan mäta olika produktionssystems konkurrensförmåga inom områdena kvalitet, leveranstid, leveranspålitlighet, kostnadsnivå, kostnadspålitlighet samt flexibilitet. Tanken med detta är att underlätta valet av produktionsprocess för byggföretag så att de använder ett produktionssystem som möter kraven från just deras kundsegment på bästa sätt.

I den andra studien har processvalets inverkan på informationsdelning inom byggföretaget och med aktörer i försörjningskedjan studerats. Studien visar att industriella byggare har en stabilare försörjningskedja med färre leverantörer och underentreprenörer jämfört med 
traditionella byggare. Den visar också att industriella byggare använder sig av IT-verktyg i större utsträckning än traditionella byggare. Detta i kombination med att industriella byggare oftast standardiserar produkten i större utsträckning än traditionella byggare underlättar arbetet med informationsdelning både inom det producerande företaget och $\mathrm{i}$ försörjningskedjan.

I den tredje studien är produktionsstrategiprocessen i fokus. I den studien har själva processen att formulera och implementera en produktionsstrategi för en industriell byggare studerats. Förslag på hur man kan arbeta för att ta fram en ny produktionsstrategi samt hur man kan göra för att implementera den har identifierats.

För att få en förankring i byggindustrin har alla studier gjorts i samarbete med byggföretag som använder olika typer av produktionssystem. Information till de olika studierna har samlats genom studiebesök, intervjuer och granskning av företagsspecifika dokument. Totalt har åtta olika produktionssystem bidragit med information till forskningens olika delar. Forskningens förankring i byggbranschen är viktig om dess resultat ska kunna användas i byggföretagens produktionsstrategiarbete. 


\section{Foreword}

The next few lines are dedicated to the persons that have supported me in my $\mathrm{PhD}$-studies. They have dedicated time and effort to help me and without them I would never have been able to get to this point, where I am only a foreword from finalising my doctoral thesis. To these persons I am forever grateful!

I want to start with thanking my supervisors Martin Rudberg and Anna Fredriksson. Martin for being the best supervisor I could ever have wished for. Your dedication and thoroughness seem to have no limits and I am so grateful for all the time and devotion you have put in to help me as a PhD-student. Anna Fredriksson for broadening the perspectives, your input has most definitely improved the quality of my research.

Secondly, I would also like to thank my colleagues (present and former) in the Construction Logistics group for a great working environment, combining serious discussions with humour (in varying quality). Thank you Micael Thunberg for taking the lead in the $\mathrm{PhD}$ process, it has made the practical issues a lot easier for me. Thank you Mats Janné, for making everyday life at the office more fun.

Thirdly, I want to thank all my colleagues at the division of Communications- and Transport Systems (CTS). Special thanks goes to Viveka Nilson, your help during my time at the university has been invaluable, and to Elisabeth Andersson for all the practical help concerning my stay in Cardiff. Finally I want to thank Ellen Grumert for all the discussions about work and life during morgonkaffe. I have been very lucky to have you as my colleague and friend throughout the PhD-studies.

Finally, I want to send all my love to my family, at the moment located in Norrköping, Stockholm, and Örnsköldsvik. I know you always have my back and support me in every part of my life. I may need it even more in the future now that I'm finally done with school and, at the age of 34 , will start working at a "real" job $(;)$.

Therese, your love and support means everything to me. I could never have pulled this through without you. I Love You, Arvid and Holger with all my heart! 



\section{Acknowledgement}

There are a number of persons that have contributed to this research that I want to thank. I am very grateful to Jesper Strandberg, Ola Dietrichson, Helena Lidelöw, Ola Magnusson, Mikael Thorgren, Lars Eriksson, Roger Pettersson, Malin Nordgren, Mats Öberg, Sverker Andreasson, Anton Lundholm, Magnus Lindskog, Refik Salievski, Henrik Johnsson, Magnus Karlsson, Lars-Åke Lindvall, Lina Andersson, Markus Holmlund, and Morgan Eriksson. Thank you all for great discussions and input to the research project. I also want to thank Dr Jonathan Gosling and Professor Mohamed Naim for a warm welcome and great discussions during my visit at Cardiff Business School. The research has been financed by The Lars Erik Lundberg Foundation for Research and Education. 



\section{Thesis Outline}

This thesis is of a compilation character (thesis by publication) comprising five articles; three of them are published in academic journals: Construction Management \& Economics, Journal of Construction Engineering and Management, and Construction Innovation respectively. One is a working paper based on a conference proceeding presented at the $24^{\text {th }}$ EurOMA conference in Edinburgh 2017, and one is a working paper submitted to the academic journal International Journal of Production Economics. The thesis is titled: Production Strategy in Project Based Manufacturing within a House-Building Context and consists of an introductory part that describes the background and purpose to the research, explains the house-building context, clarifies the theoretical frame of reference, and presents the research questions. After that the research process is described, the results are presented and discussed and finally the main contributions of this research are presented. The second part of the thesis includes the five papers that the research builds' upon. The papers are listed below:

\section{Paper 1}

Jonsson, H. and Rudberg, M. (2014). "Classification of production systems for industrialized building: a production strategy perspective". Construction management and Economics, 32(1-2), 53-69.

\section{Paper 2}

Jonsson, H. and Rudberg, M. (2015). "Production System Classification Matrix: Matching Product Standardization and Production System Design”. Journal of Construction Engineering and Management, Vol 141, Issue 6.

\section{Paper 3}

Jonsson, H. and Rudberg, M. (2017). "KPIs for Measuring Performance of Production Systems for Residential Building”. Construction Innovation, Vol 17, No. 3, 381-403.

\section{Paper 4}

Jonsson, H. and Gosling, J. (2017). "Information exchange in house-building - a production strategy perspective". Working paper, based on proceedings from the $24^{\text {th }}$ EurOMA conference, $1-6^{\text {th }}$ of June 2017, Edinburgh Scotland.

\section{Paper 5}

Jonsson, H. and Fredriksson, A. (2017). "Production strategy process - formulation and implementation in an industrialised house-building context". Working paper submitted to International Journal of Production Economics. 

"I'm (still) a lucky man, to count on both hands the ones I love"

Eddie Vedder (2009) 



\section{Table of contents}

1. Introduction

1.1 Background

1.2 Scope and limitations 3

2. The house-building context $\quad 7$

2.1 The house-building industry in Sweden today 7

2.2 House-building projects 8

2.3 Industrialised house-building 9

2.3.1 Process model of industrialised house-building 10

2.3.2 Classifying different types of house-building production systems 12

2.4 House-building supply chains and information exchange challenges 14

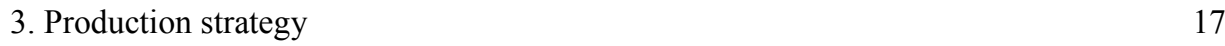

$\begin{array}{ll}3.1 \text { Overview and definition } & 17\end{array}$

$\begin{array}{ll}3.2 \text { Production strategy content } & 19\end{array}$

3.2.1 Competitive priorities 19

3.2.2 Decision categories 23

3.3 Production strategy process 29

3.3.1 Production strategy formulation $\quad 29$

3.3.2 Production strategy implementation 30

3.4 Performance measurement 32

3.4.1 Key performance indicators (KPI) 34

4. Research questions $\quad 37$

$\begin{array}{ll}4.1 \text { Research question } 1 & 37\end{array}$

4.2 Research question $2 \quad 38$

4.3 Research question $3 \quad 38$

4.4 Research question 4

5. Research design 41

5.1 Overview of the research process 41

5.2 Study 1: Process choice and performance measurement 46

5.2.1 Research design and process Study $1 \quad 46$ 
5.2.2 Method Study $1 \quad 48$

5.3 Study 2: Information exchange in house-building 52

5.3.1 Research design and process Study 2

5.3.2 Method Study 2

5.4 Study 3: Production strategy process $\quad 54$

5.4.1 Research design and process Study $3 \quad 54$

5.4.2 Method Study 3

5.5 Research quality 56

$\begin{array}{ll}\text { 5.5.1 Reliability } & 57\end{array}$

5.5.2 Construct validity 58

5.5.3 Internal validity $\quad 58$

5.5.4 External validity $\quad 59$

6. Results 61

6.1 Classification of production systems in house-building 61

6.2 Performance measurement 64

6.3 Information exchange in house-building $\quad 69$

6.4 Formulation and implementation of production strategy in industrialised housebuilding $\quad 72$

$\begin{array}{ll}\text { 7. Discussion and further research } & 75\end{array}$

7.1 Practical implications $\quad 75$

$\begin{array}{ll}\text { 7.1.1 Evaluating two different production systems } & 75\end{array}$

$\begin{array}{ll}\text { 7.1.2 Performance measurement } & 77\end{array}$

$\begin{array}{ll}\text { 7.1.3 Production systems off the diagonal } & 77\end{array}$

$\begin{array}{ll}\text { 7.1.4 Information exchange in a house-building context } & 79\end{array}$

$\begin{array}{ll}\text { 7.1.5 Redesigning a production system } & 80\end{array}$

$\begin{array}{ll}7.2 \text { Reflections and further research } & 81\end{array}$

8. Contribution 85

References $\quad 89$ 
Paper 1 - Classification of production systems for industrialised building: A production strategy perspective

Paper 2 - Production System Classification Matrix: Matching Production Standardisation and Production-System design

Paper 3 - KPIs for measuring performance of production systems for residential buildings: A production strategy perspective

Paper 4 - Information exchange in house-building: A production strategy perspective

Paper 5 - Production strategy process: Formulation and Implementation in an industrialised house-building context 



\section{Introduction}

Focus in this thesis is the production of multi-family houses. The research highlights strengths and weaknesses of typical production systems having different product and process characteristics. The research also study how to measure performance at a production strategy level, and how the design of the production system affects information exchange. Finally the production strategy process is researched by studying production strategy formulation and implementation in an industrialised house-building context.

\subsection{Background}

To be able to effectively manage the different challenges that the production function faces a production strategy has to exist. A production strategy helps a company to make operational and strategic decisions that follow a logical pattern that supports the corporate strategy and the competitive priorities of the company (Hill and Hill, 2009). When no strategy exists the decisions may be arbitrary and unpredictable (Miltenburg, 2005), leading to an underachieving production system. Production strategy involves decisions that shape the long term capabilities of a producing company, in order to be competitive in the marketplace, by linking market requirements and production resources (Miltenburg, 2005, Slack and Lewis, 2011). Since Skinner (1969) in his seminal work identified production as the missing link in corporate strategy a number of structured production strategy frameworks have been developed to facilitate the work with production strategy in the production industry (see e.g. Hayes and Wheelwright, 1979, Hayes and Wheelwright, 1984, Hill and Hill, 2009, Miltenburg, 2005, Slack and Lewis, 2011). These frameworks have been shown useful for producing firms when designing new production systems, or when improving already existing ones.

One of the more important decisions a producing company has to make concerns the products and choosing a suitable production process by which to make them (Hill and Hill, 2009). To facilitate this, the so called process choice, Hayes and Wheelwright (1979) introduced the product-process matrix (Figure 1). In that matrix the correlation between different types of process layouts, e.g. continuous processing, line flow, batch flow, job shop and project, and the product structure, i.e. production volume and degree of standardisation (low/low to high/high) are visualised. However, in traditional production strategy literature project based production (see top left corner of the product-process matrix in Figure 1) is described in general terms as only one type of production system (see e.g. Hill and Hill, 2009) or left out of the scope due to the unique characteristics of those one-off products (see e.g. Miltenburg, 2005). 


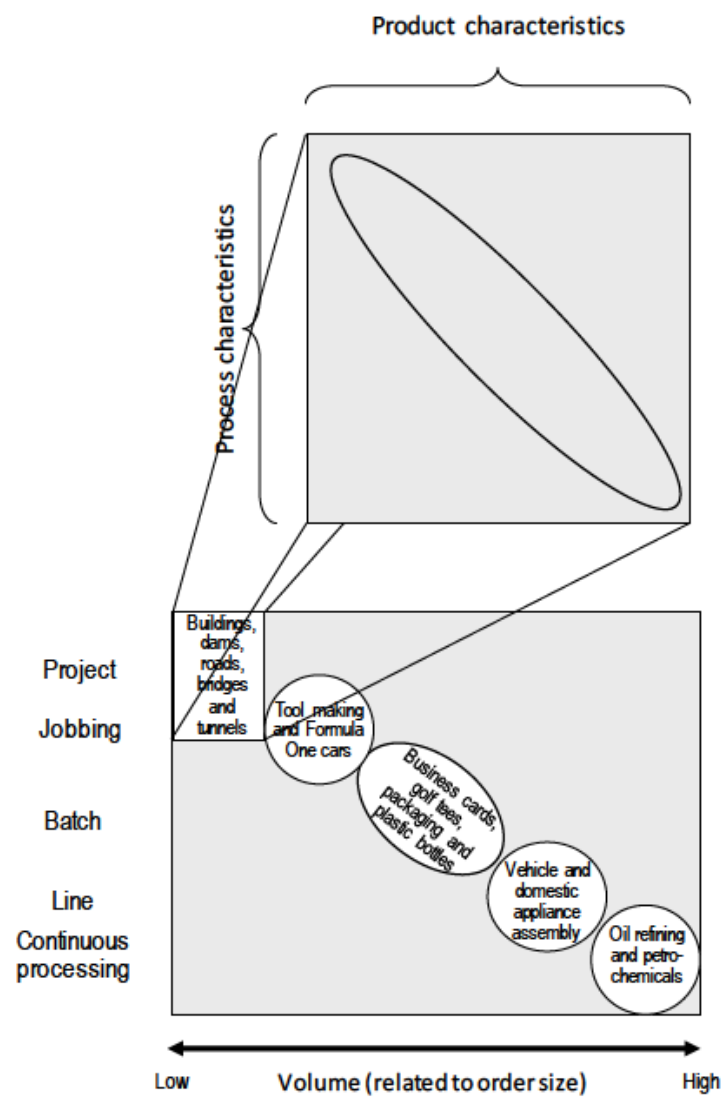

Figure 1 The focus of this thesis is the project based part of the product-process matrix (Hayes and Wheelwright, 1979)

To increase the understanding of project based production the house-building industry is studied. The house-building industry is project based and the conditions and prerequisites are different between different types of projects. This indicated that a production system designed for one project might not be the best choice for another meaning that a production system has to be designed to meet the targeted market in the most effective way. How it should be designed varies depending on the market requirements. There are different ways of producing houses and one way of separating different production systems in housebuilding is traditional on-site production compared to different types of off-site production systems (see e.g. Gibb, 2001). Compared to traditional production on-site, off-site production has been said to have a number of advantages, mainly in productivity related outputs such as production cost, quality and delivery speed, to name a few (Kadir et al., 2006, Meiling et al., 2012). The trade-off when increasing the degree of off-site production is reduced product and process flexibility. The trade-off between productivity and flexibility indicates that different production systems perform well in different areas of competition, and that a sound production strategy, that aids decision making when designing the production system, is important also in a house-building context. However, 
research that classify different types of production systems for production of multi-family houses (e.g. Barlow et al., 2003, Barlow and Ozaki, 2005, Halman et al., 2008) do not explicitly treat the trade-off between productivity and flexibility and thereby neglect the important link between market requirements and the design of the production system. To be successful this link between the market (customers and competition) and production must be taken into consideration. Strategic decisions concerning the design of the production system must be taken so that the production system is aligned with the other functions (e.g. marketing, design, finance etc.) in the company. A production strategy framework, adapted to a house-building context, would help companies develop competitive production systems designed to meet the targeted market in the most effective way. Since construction related research typically do not take a production strategy perspective on house-building and since traditional production strategy literature typically do not treat project based manufacturing in detail:

The purpose of this research is to extend the production strategy body of knowledge concerning project based production, in the context of house-building.

From a broader perspective it is important to extend the production strategy body of knowledge in a house-building context since the house-building industry involves and affects a large part of the society. In 2016 multi-family residences represented about $80 \%$ of the total number of residences produced in Sweden (SCB, 2017). The reason for focusing on the production of multi-family residences in this research is related to aspects such as an increasing demand for both rental apartments and condominiums (Boverket, 2012), and the fact that the relative amount of money a family spends on their accommodation increases (Lind and Song, 2012). Producing houses in an effective and efficient way, using a sound production strategy, should have a positive impact on the ability to meet future demand for residential houses and offering affordable accommodation. Another issue is the increasing production costs and decreased productivity highlighted in various reports (Larsson et al., 2013). A sound production strategy should have a positive impact on housebuilding companies and other stakeholders, e.g. clients, suppliers, sub-contractors and end users, within the house-building industry. This research can help house-building companies to successfully formulate and implement competitive production systems meeting market requirements in the best possible way. The potential result is a more effective production process, and in the end a more successful business. This can potentially lead to decreased costs for the clients and in the end of the chain reduced rent for the end user or reduced fees from the housing cooperatives.

The results presented in this thesis give researchers a deeper understanding of project based production and house-building companies a tool to work with production strategy in a structured way.

\subsection{Scope and limitations}

In this research the house-building industry is in focus. Different production systems, e.g. with different degrees of off-site assembly, for production of multi-family houses are 
investigated and analysed. A multi-family house is a building designed to house several families in separate housing units. Smaller projects such as single-family residences, larger projects, for example big arenas, and civil engineering projects, e.g. roads, railway, and bridges, are not taken into consideration in this research.

The research rest upon production strategy research as the theoretical base. Production strategy can also be termed manufacturing strategy (Chatha and Butt, 2015, Dangayach and Deshmukh, 2001, Miltenburg, 2005) or operations strategy (Slack and Lewis, 2011). There are some differences between the definitions but for most parts they have been used interchangeably over the years (Mirzaei, 2015). They are also used interchangeably in this thesis but in most parts the term production strategy is used for consistency.

The unit of analysis is production processes that produce multi-family houses as the output, i.e. the complete house is the finished good. In this research the production systems are defined by the actors involved in producing the house, i.e. the unit of observation in Figure 2. The focal actor in the house-building production process is the main contractor that is responsible for producing the house, i.e. the unit of analysis in Figure 2. Sub-contractors, suppliers, clients, etc., are considered but always in relation to the production system of the main contractor. The two parts of Figure 2 describe the production system for both traditional production on-site and for a production system with some degree of off-site production. Both these types of production systems are considered in this research.

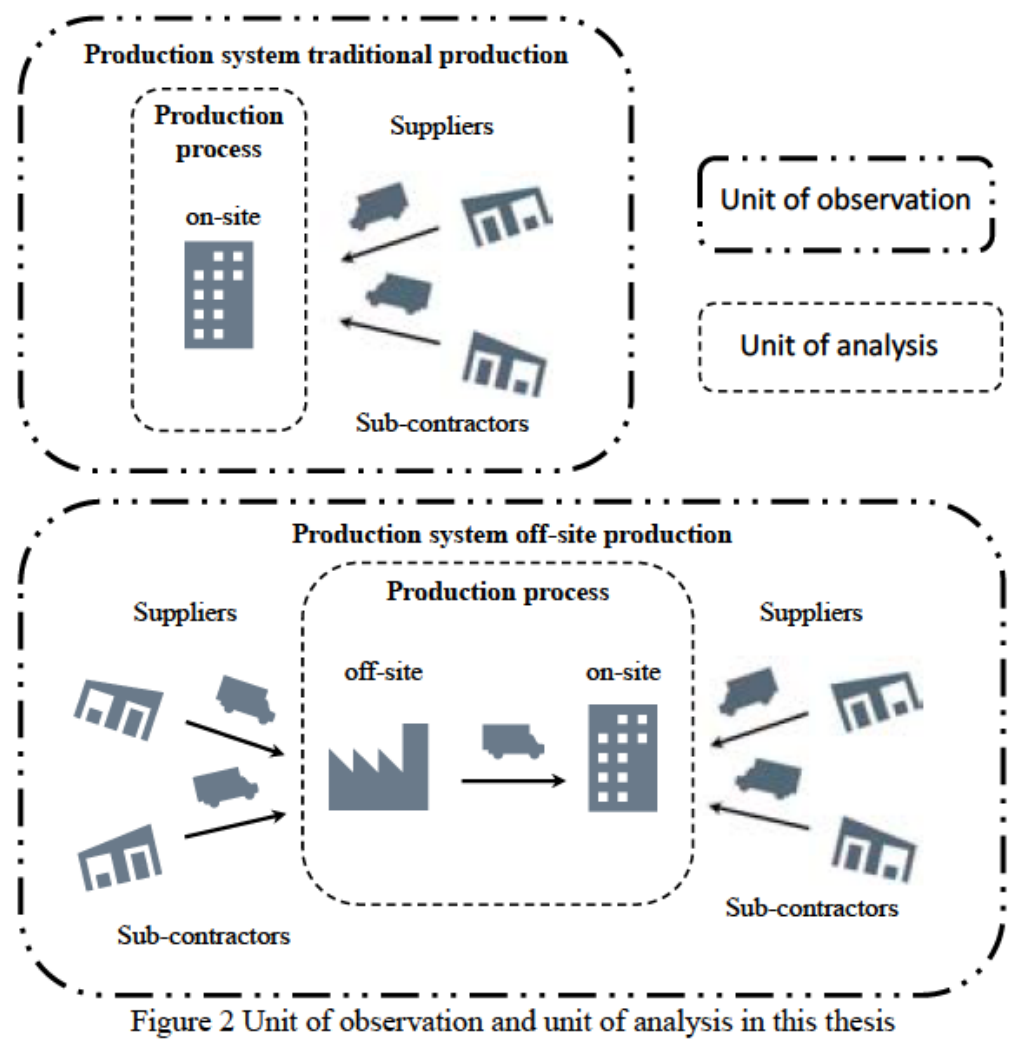


For the empirical part of this research case studies were chosen as the primary research method. The companies used in this research are all firms operating in Sweden using production systems with various degrees of off-site production. A production system using some degree of off-site production is termed different in different literature. The terms in use can be grouped, by affix, under four categories (Pan et al., 2012):

- Off-site (e.g. off-site construction, fabrication, manufacturing, production, assembly),

- Pre- (e.g. pre-assembly, fabrication, work),

- Modern (e.g. modern methods of construction), and

- Building/house-building (e.g. industrialised building, industrialised housebuilding, system building, non-traditional house-building).

In this thesis the terms above are used interchangeably but in most parts the terms industrialised house-building and off-site production are used for consistency. Traditional on-site production is considered as a baseline benchmark, and is treated as one concept when in reality you can produce buildings on-site in different ways and adapting different strategies within the concept depending on the prerequisites. 



\section{The house-building context}

The theoretical base for the research is production strategy and it is important to understand the context specific characteristics of the house-building industry to be able to extend production strategy theory to include project based manufacturing. This chapter gives an overview of the house-building industry and production of multifamily houses in Sweden.

\subsection{The house-building industry in Sweden today}

Today in Sweden there is lack of residential buildings. According to the Swedish Construction Federation (Sveriges Byggindustrier), which represents construction industry interests in Sweden, there is a lack of residential houses in 255 out of Sweden's 290 municipalities. The pressure to produce residential buildings are now higher than ever (Boverket, 2012) due to a number of factors, for example young people looking for their first apartment, and the current situation in Europe concerning refugees that comes to Sweden and must be provided with homes where they can feel safe and welcome. The increased demand has also led to an increase in production of residential buildings. Statistics (Statistics Sweden SCB, 2017) shows that the industry have not produced and completed as many residential apartments as they did in 2016, since 1992. However, what also is shown is that, if the goal to produce 700000 residential houses in the next ten years (Boverket, 2016) is to be reached, the annual production volume has to be even higher. The largest challenge for the industry to meet this demand is a lack of personnel, both blue and white collar workers. Seven out of ten companies, associated with the Swedish Construction Federation, states that they have a hard time finding personnel to their organisations (Sveriges Byggindustrier, 2017).

At the same time as the demand for residential houses are higher than ever, the housebuilding industry is considered less progressive than other industries (Landin and Oberg, 2014). Various evaluation initiatives report about increasing production costs and decreased productivity (Larsson et al., 2013), and that the relative amount of money a family spends on their accommodation increases due to factors such as, e.g. high production costs and a lack of residential apartments (Lind and Song, 2012). To be able to meet the challenges of today and tomorrow houses have to be produced in a more effective and efficient way. One suggested way to do this is to move some of the value adding activities of the house-building project off-site, to a more industrial environment. This way of producing houses can reduce production time and cost while improving quality, safety and sustainability. By producing parts of the houses in a controlled, industrial environment a company may also be able to remain competitive with a smaller, lower skilled, workforce compared to traditional production on-site (Grosskopf et al., 2017). 


\subsection{House-building projects}

A project can be defined as a series of activities that seeks to realise a unique and innovative deliverable, e.g. a product or a service. A project has a defined start and end, and also allocated recourses for the specific task that is the project (see e.g. Lessing et al., 2015, Mesly, 2017). Simply described a house-building project can be divided into four main phases, i.e. pre-project, pre-production, production and post-production (see e.g. Cooper et al., 1998, Klinger and Susong, 2006). Activities within each phase can differ a bit from project to project but for a, general contract, house-building project the following activities are recognised, see Table 1:

Table 1 Phases in a general contract house-building project

\begin{tabular}{|c|c|c|c|}
\hline Phase & $\begin{array}{l}\text { Relation to } \\
\text { this research }\end{array}$ & Activities & $\begin{array}{l}\text { Relevant } \\
\text { references }\end{array}$ \\
\hline Pre-project & Not included & $\begin{array}{l}\text { - Determining the need for the project } \\
\text { - Securing financial authority to proceed with } \\
\text { the pre-production phase }\end{array}$ & $\begin{array}{l}\text { (Cooper et al., } \\
1998)\end{array}$ \\
\hline $\begin{array}{l}\text { Pre- } \\
\text { production }\end{array}$ & $\begin{array}{l}\text { Included, } \\
\text { only partly } \\
\text { considered }\end{array}$ & $\begin{array}{l}\text { - Owners planning and budgeting } \\
\text { - Determining clients need } \\
\text { - Design } \\
\text { - Delivering approved production information } \\
\text { - Contractor selection }\end{array}$ & $\begin{array}{l}\text { (Al-Reshaid et } \\
\text { al., 2005, Klinger } \\
\text { and Susong, } \\
\text { 2006, Riley and } \\
\text { Cotgrave, 2013) }\end{array}$ \\
\hline Production & $\begin{array}{l}\text { Included, } \\
\text { main focus }\end{array}$ & $\begin{array}{l}\text { - Production of the project solution } \\
\text { - Hand over }\end{array}$ & $\begin{array}{l}\text { (Cooper et al., } \\
\text { 1998, Riley and } \\
\text { Cotgrave, 2013) }\end{array}$ \\
\hline $\begin{array}{l}\text { Post- } \\
\text { production }\end{array}$ & Not included & $\begin{array}{l}\text { - Use } \\
\text { - Monitor and manage maintenance needs of } \\
\text { the constructed facility }\end{array}$ & $\begin{array}{l}\text { (Cooper et al., } \\
\text { 1998, Klinger and } \\
\text { Susong, 2006) }\end{array}$ \\
\hline
\end{tabular}

In this research the main focus is on the production phase even though some parts of the pre-production phase are considered, e.g. determining clients' need and design. The preproject and post-production phases are also affected by the production strategy of the company but left out of the scope in this research.

Riley and Cotgrave (2013) divide the production phase of a house-building project in to six steps, see Figure 3.

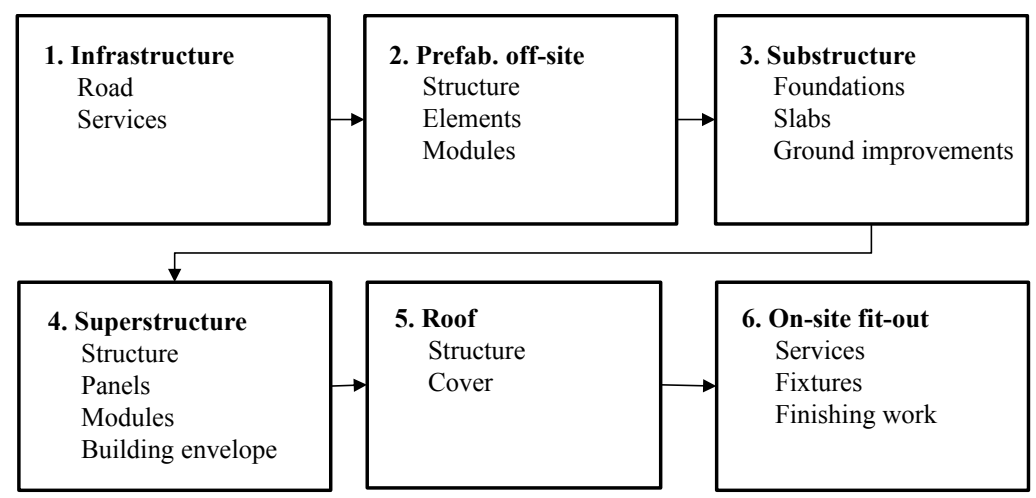

Figure 3 Steps in the production phase of a house-building project (Riley and Cotgrave, 2013) 
The first step in a house-building project is to establish the infrastructure needed to be able to build the house. Roads (permanent or temporary) have to be in place to access the construction site. Services such as electricity, water, site huts, and temporary offices are also part of establishing the construction site infrastructure.

The third step (Figure 3) is to set the substructure of the building. Proper ground improvements have to be made, and a foundation has to be built. When the substructure is in place the project continue with producing the superstructure in terms of structural framework, panels, inner walls, floor structure etc., and after that the roof structure is built and covered to seal the building. Finally the finishing work is put in to complete the house.

The second step, pre-fabrication off-site, is not applicable in all house-building projects and how much of the building that is produced off-site varies from project to project. However off-site production, i.e. producing parts of the house in an off-site facility, is relatively common, and production systems using different degrees of off-site assembly exists and compete on the house-building market today. Industrialised house-building compared to traditional production methods on the construction site is central when making the process choice in a house-building context, hence is important form a production strategy perspective in a house-building context.

\subsection{Industrialised house-building}

In this thesis the following definition of industrialised house-building is used:

"Industrialised house-building is a thoroughly developed house-building process with a well-suited organisation for efficient management, preparation and control of the included activities, material flows, resources and results for which prefabricated components are used in order to create maximum customer value" (Lessing, 2006 p. 93, Lidelöw et al., 2015 p. 130).

As the definition is formulated it becomes clear that industrialised house-building is more comprehensive than just using prefabricated components in the production process (Lessing et al., 2015). This more comprehensive view of industrialised house-building can be related to traditional production strategy literature and the use of prefabricated elements can be seen as one, although important, decision amongst many decisions a company have to make when designing their production system. As can be seen in the definition of the production system (Figure 2), the production systems includes the production process(es) and the suppliers and sub-contractors involved in it. Production strategy, i.e. the pattern of decisions that form the production system, has a wider scope and involves different functions in the organisation such as marketing, finance, engineering, etc. It also involves other decisions that just the degree of prefabrication such as make or buy decisions, capacity, facilities, process technology, organisation, etc. In production strategy literature these are called decision categories and are described in more detail in chapter 3. 


\subsubsection{Process model of industrialised house-building}

Pan et al. (2012) investigated strategies for integrating off-site production in housebuilding. They related different stages in the project, i.e. land acquisition and design, presite, on-site and post-site, to the opportunity for off-site integration. They concluded that the best opportunity for off-site integration is early in the house-building project and that the opportunity disappear at the end of the land acquisition stage, see Figure 4.

\begin{tabular}{|l|c|c|c|}
\hline $\begin{array}{l}\text { Stages of house- } \\
\text { building }\end{array}$ & Land acquisition/design & $\begin{array}{l}\text { On- } \\
\text { site }\end{array}$ & Post-site \\
\hline $\begin{array}{l}\text { Opportunity } \\
\text { for off-site } \\
\text { integration }\end{array}$ & $\begin{array}{l}\text { Best opportunity for } \\
\text { off-site integration }\end{array}$ \\
\hline
\end{tabular}

Figure 4 Stages in a house-building project and timing of opportunity to integrate the use of offsite production (Pan et al., 2012)

The decision to use off-site production as part of the production system is a strategic decision that has to be taken early as it affect the competitiveness and the ability of a specific production system to target a specific market.

Just as there are different types of production systems for traditional production there are different ways of producing multi-family houses. Lessing (2006) introduced a process model for industrialised house-building in which eight areas should be considered when describing industrialised house-building. These eight areas can be categorised under four different platforms (in this thesis the word platform is used only when describing the process model for industrialised house-building and is not elaborated further), see Table 2.

Table 2 Areas defining industrialised house-building (Lessing, 2006)

\begin{tabular}{|l|l|}
\hline Platform & Areas to consider in industrialised house-building \\
\hline Knowledge platform & Performance measurement and knowledge transfer \\
\hline Technical platform & Technical systems \\
\cline { 2 - 2 } & Off-site production \\
\cline { 2 - 2 } & The use of ICT-solutions \\
\hline \multirow{3}{*}{ Supply platform } & Logistics integrated in the building process \\
\cline { 2 - 2 } & Long term relations \\
\hline Process platform & Customer focus \\
\cline { 2 - 2 } & Planning and control of the process \\
\hline
\end{tabular}

A move towards industrialised house-building means a shift from strictly project based production to a more process oriented production. Along with the eight areas of industrialised house-building Lessing (2006) also presented a process model describing how to work with the development and continuous improvements of the platforms related to the house-building process (Figure 5). The houses are still produced in projects but the projects are not isolated parts in the production system but rather integrated parts in a much larger building process. 


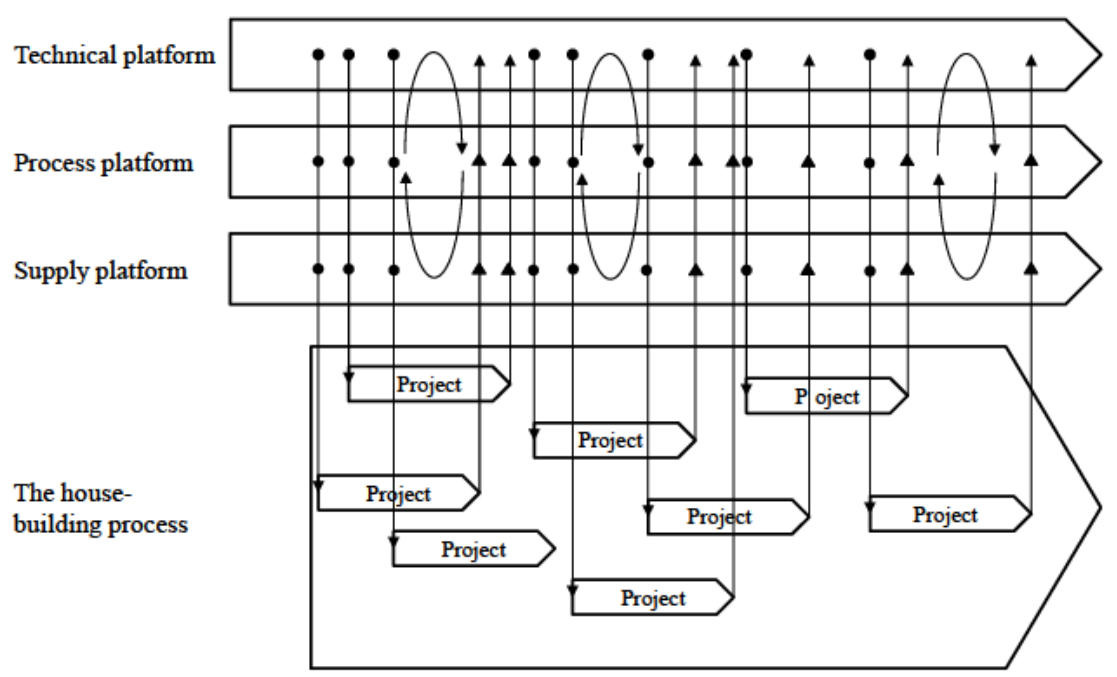

Figure 5 Continuous improvements of the platforms (Lessing, 2006)

The technical solutions of the building system are defined in the technical platform, instructions and guidelines regarding the production process are defined in the process platform, and the directions concerning suppliers and subcontractors are defined in the supply platform. The platforms are then used to produce the houses in each project. At the end of each project feedback is sent back to the organisation responsible for developing each platform and used to revise and improve the platforms. This process of continuous improvement is represented by the cycling arrows in Figure 5, and this also represent the knowledge platform that is integrated and part of the other three platforms visualised in Figure 5. The different platforms are related to each other, also indicated by the cycling arrows, and a change in one platform will affect the other platforms. Therefore it is important to see the different platforms and processes as parts of an integrated system. To be successful all parts must work together to achieve company and business goals. Depending on the content in and design of the platforms different production systems have different characteristics and ability to perform. In this research comparison between different production systems is made and to be able to do this different production systems have to be categorised/classified. 


\subsubsection{Classifying different types of house-building production systems}

Kamar et al. (2011) made a comparison between different classifications of production systems in construction and from that review they derived the following seven generic production systems:

1. Frame system

2. Panellised system

3. On-site fabrication

4. Sub-assembly and components

5. Block work system

6. Hybrid system

7. Volumetric and modular system

In a list of different ways to classifying industrialised house-building systems presented in Kamar et al. (2011) one can see that most classifications are based on how much of the building is produced off-site. In a comparative study Azman et al. (2010) give examples of how off-site production systems are categorized in different countries, see Table 3.

Table 3 Categorisation of production systems in different countries (Azman et al., 2010)

\begin{tabular}{|c|c|}
\hline Country & Categorisation of production system \\
\hline $\mathbf{U S}$ & $\begin{array}{l}\text { - } \text { Off-site pre-assembly } \\
\text { - } \text { Hybrid system } \\
\text { - } \text { Panellised system } \\
\text { - } \quad \text { Modular building }\end{array}$ \\
\hline UK & $\begin{array}{l}\text { - Component manufacture \& sub-assembly } \\
\text { - Non-volumetric pre-assembly } \\
\text { - Volumetric pre-assembly } \\
\text { - Modular building }\end{array}$ \\
\hline Australia & $\begin{array}{l}\text { - Non-volumetric pre-assembly } \\
\text { - Volumetric pre-assembly } \\
\text { - } \text { Modular building }\end{array}$ \\
\hline Malaysia & $\begin{array}{l}\text { - } \text { Pre-cast concrete system } \\
\text { - } \text { Formworks system } \\
\text { - } \text { Steel framing systems } \\
\text { - Prefabricated timber framing systems } \\
\text { - } \text { Block work systems } \\
\text { - Innovative product systems }\end{array}$ \\
\hline
\end{tabular}

The categorization used in UK was defined by Gibb (2001) and represent four types of production systems with varying degrees of off-site production ranging from component manufacture and sub-assembly, which is the traditional way of producing buildings on-site, to modular building. This way of categorising different production systems include traditional production on-site which is not included in the categorisations used in the US, Australia and Malaysia. In this research both industrialised production systems and more traditional production on the construction site are considered, hence Gibb's (2001) four types of production systems, including production both on-site and off-site, are relevant as a base in this research. The four production systems are defined in Table 4. 
Table 4 Production systems defined by (Gibb, 2001)

\begin{tabular}{|l|l|}
\hline $\begin{array}{l}\text { Component manufacture } \\
\text { and sub-assembly }\end{array}$ & $\begin{array}{l}\text { Many components used in construction are actually sub-assemblies, e.g. } \\
\text { door furniture or light fittings. This category includes all small scale sub- } \\
\text { assemblies that would never be considered for on-site assembly in any } \\
\text { developed country. (Gibb, 2001, p. 308) }\end{array}$ \\
\hline $\begin{array}{l}\text { Non-volumetric pre- } \\
\text { assembly }\end{array}$ & $\begin{array}{l}\text { These items are assembled in a factory, or at least prior to being placed } \\
\text { in their final position. They may include several sub-assemblies and } \\
\text { constitute a significant part of the building or structure. Examples } \\
\text { include wall panels, structural sections and pipework assemblies. (Gibb, } \\
\text { 2001,p. 309) }\end{array}$ \\
\hline Volumetric pre-assembly & $\begin{array}{l}\text { These items are also assembled in a factory. They differ from non- } \\
\text { volumetric in that they enclose usable space and usually are installed on- } \\
\text { site within an independent structural frame. Examples include toilet } \\
\text { pods, plant room units, pre-assembled building services risers and } \\
\text { modular lift shafts. (Gibb, 2001, p. 309) }\end{array}$ \\
\hline Modular Building & $\begin{array}{l}\text { These items are similar to volumetric units, but in this case the units } \\
\text { themselves form the building, as well as enclosing useable space. They } \\
\text { may be clad externally on-site with 'cosmetic' brickwork as a secondary } \\
\text { operation. Examples include office blocks and motels and concrete } \\
\text { multi-storey modular units used for residential blocks. (Gibb, 2001, p. } \\
\text { 309) }\end{array}$ \\
\hline
\end{tabular}

Compared to the seven production systems defined by Kamar et al. (2011), where on-site is included, it can be argued that:

- On-site fabrication and sub-assembly and components correspond to component manufacture and sub-assembly

- Panelised system correspond to non-volumetric pre-assembly

- Block work system correspond to volumetric pre-assembly

- Volumetric and modular system correspond to modular building

The hybrid system is a combination of two or more of the production systems defined in Gibb (2001) and to include that systems as a generic production system is not considered necessary. Frame system describes pre-fabricated framing systems but since a structural framework is included in all types of buildings the framing systems are included in all four production systems defined by Gibb (2001). For the reasons given above it is considered that the four production systems defined by Gibb (2001) give a good representation of different production systems used for house-building.

Literature state that the main barriers for using off-site production are high capital cost, difficulties to achieve economies of scale, complex interfaces between different systems and the inability to freeze the design early in the process (Pan et al., 2008). The main drivers for using off-site production are increased quality, time, cost, and reduced health and safety issues (see e.g. Blismas et al., 2006, Gibb and Isack, 2003, Jaillon and Poon, 2008). The fact that different types of production systems have strengths and weaknesses in different areas of competition indicates that there are differences in competitiveness, and that one type of production system cannot meet all types of demands. Instead a production system has to be designed to meet the targeted market in the most effective way and how it should 
be designed varies depending on the market requirements. As stated above and visualised in Figure 2, a house-building production system also include suppliers and subcontractors, hence the supply chain have to be managed and information has to be exchanged, not only within the organisation of the house-builder, but also with actors in the supply chain.

\subsection{House-building supply chains and information exchange challenges}

House-building projects involve multiple organisations in an interdisciplinary environment and typical stakeholders in a house-building project are, e.g. main contractor, subcontractors, suppliers, clients, architects, etc. A typical supply chain in the house-building industry consists of raw material suppliers, component suppliers, resellers/wholesalers, offsite pre-fabrication, on-site production, and clients. The flow of materials flow downstream in the supply chain and the flow of information flows upstream, see Figure 6.

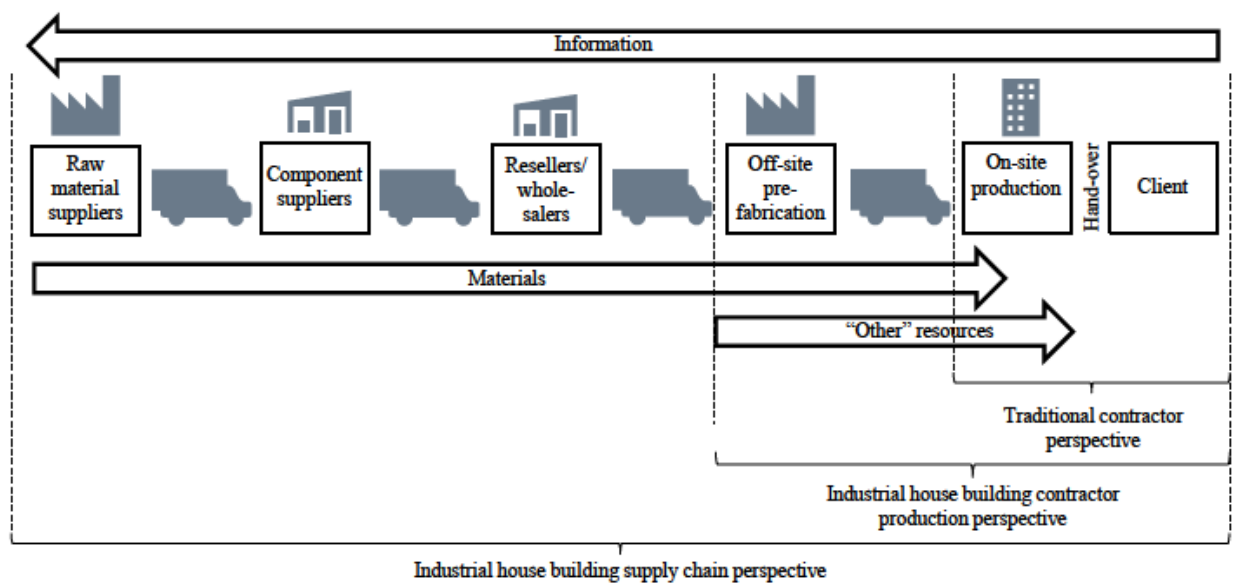

Figure 6 Supply chain in house-building (Erikshammar, 2013)

The house-building supply chain is described as long and fragmented as a result of outsourcing many special trades, different geographical locations for each project, and the large amount of materials that are used to build the house. The result is many levels and layers of contracts and subcontractors that have to be coordinated and it is difficult to see the bigger picture of a house-building project (Dubois and Gadde, 2002). This also makes the trust and long term relations with suppliers needed for effective collaborations and information exchange hard to achieve (Cox et al., 2003, Dainty et al., 2006). Housebuilding projects are typically engineered-to-order and each project, typically, has a degree of uniqueness. This means that the supply chain has to cope with design revisions, new engineering work and new or adapted processes which adds to the complexity and the need to coordinate design information (Schoenwitz et al., 2017). The use of proper ICTsolutions, e.g. ERP-systems, BIM, digital project portals etc., could be one way of mitigating the challenges described above and improve operational efficiency, improve quality, improve project time and to increase profit levels (Dehlin and Olofsson, 2008). However, there is a reluctance to embrace new ICT-solutions and generally ICT-systems 
are not considered compatible with the need of the industry (Bergström and Stehn, 2005). The resistance to change, and lack of innovation across the construction industry is well documented. New ICT-technologies are not well adopted so the mechanisms for effective and efficient information exchange are not in place (Hong-Minh et al., 2001).

The characteristics of the house-building industry described above make the use of effective information exchange extremely important and also very difficult. The shortcomings in information exchange across the supply chain has been shown to be one of the most important and persistent issues facing organisations (Fiala, 2005). In housingbuilding, where there are many stakeholders, such as the client, main contractor, subcontractors, suppliers, engineers, architects, a wide range of project information must be co-ordinated to ensure success of a project (Senaratne and Ruwanpura, 2016). Deficiencies regarding information exchange are one of the most common project risks in construction and cause lower performance, increases unnecessary expenditure and affects the process and quality of the project negatively (Senaratne and Ruwanpura, 2016).

Kembro et al. (2014) identified four aspects of information exchange in supply chains, i.e. (1) Why (not) share information, (2) What information to share with whom, (3) How to share information, and (4) Prerequisites, barriers and drivers. If these aspects are considered, and handled properly, problems occurring due to poor information management can be reduced.

The difficulties of information exchange in house-building supply chains have been addressed in previous research (see e.g. Dainty et al., 2006, Senaratne and Ruwanpura, 2016). However, most research on information exchange in construction consider traditional, on-site, production methods or, in a few cases, industrialised housing (see e.g. Bergström and Stehn, 2005, Persson et al., 2009) and do not appreciate differences between different types production systems. As noted by Kembro et al. (2014), information exchange in the supply chain is context dependent and "one size does not fit all" (Kembro et al., 2014 p. 618).

Studies of industrial data systems show that as the complexity of service increases (for instance by increasing customisation requirements), the information exchange architecture may have to take more collaborative forms of inter-organizational connectivity (Wang et al., 2007). Further, a greater degree of customer interaction and customisation often means a greater information richness that has to be processed and shared (Slack and Lewis, 2011). A more flexible/agile production system is founded on information technology (Miltenburg, 2005) that can cope with the increased level of customer interaction.

In a project with a high degree of customisation and most of the production undertaken onsite, resulting in the co-ordination of many components and suppliers, as well as the coordination of a lot of design and engineering work, information exchange must be handled in one way. A higher degree of product standardisation where parts of the house are produced off-site and assembled on-site, requiring careful synchronisation of standard modules. This puts different demands on information exchange and within this space an 
information planning system, such as ERP which are widely argued to be challenging in customised environments, may become more suitable (Jin and Thomson, 2003). Higher levels of standardisation needs an ICT-system that can to cope with timing and synchronization of prefabricated components compared to a the demands on information management in a project using traditional production methods and a high degree of customisation (Persson et al., 2009).

In Table 5 four challenges, derived from literature, in a construction project environment and the implications for information exchange are presented.

Table 5 Challenges with information exchange in construction

\begin{tabular}{|l|l|ll|}
\hline $\begin{array}{l}\text { Challenge in a } \\
\text { construction project } \\
\text { environment }\end{array}$ & \multicolumn{1}{|c|}{ Implication for information exchange } & Relevant Papers \\
\hline $\begin{array}{l}\text { 1. Temporary supply } \\
\text { chains, due to project } \\
\text { environment }\end{array}$ & $\begin{array}{l}\text { This makes the trust and long term collaborations } \\
\text { needed for effective information exchange in the } \\
\text { supply chain very difficult to achieve. }\end{array}$ & $\begin{array}{l}\text { (Cox et al., 2003, } \\
\text { Dainty et al., 2006) }\end{array}$ \\
\hline $\begin{array}{l}\text { 2. Long and } \\
\text { fragmented supply } \\
\text { chains, as a result of } \\
\text { outsourcing many } \\
\text { specialist trades }\end{array}$ & $\begin{array}{l}\text { This results in many levels and layers of contracts } \\
\text { and subcontracts. It is difficult to see the bigger } \\
\text { picture and incentivise transparent information } \\
\text { exchange. It is a 'loosely coupled system', and } \\
\text { commercial tendering models tend to exacerbate the } \\
\text { problem. }\end{array}$ & $\begin{array}{l}\text { (Dubois and Gadde, } \\
\text { 2002) }\end{array}$ \\
\hline $\begin{array}{l}\text { 3. Projects are } \\
\text { engineer-to-order, } \\
\text { since each project has } \\
\text { a degree of } \\
\text { uniqueness }\end{array}$ & $\begin{array}{l}\text { The result of this is that the supply chain must cope } \\
\text { with the consequences of customisation, typically } \\
\text { leading to the need for design revisions, new } \\
\text { engineering work and new or adapted processes. } \\
\text { This introduces significant complexity, and the need } \\
\text { to coordinate design information. }\end{array}$ & $\begin{array}{l}\text { (Schoenwitz et al., } \\
\text { 2017) }\end{array}$ \\
\hline $\begin{array}{l}\text { 4. Reluctance to } \\
\text { embrace new ICT- } \\
\text { solutions, caused by a } \\
\text { complex range of } \\
\text { issues. }\end{array}$ & $\begin{array}{l}\text { The resistance to change, and lack of innovation, } \\
\text { across the construction sector is well documented. } \\
\text { New ICT-technologies are not well adopted across } \\
\text { the industry, so the mechanisms for information } \\
\text { exchange are not in place. }\end{array}$ & $\begin{array}{l}\text { (Bergström and Stehn, } \\
\text { 2005, Dehlin and } \\
\text { Olofsson, 2008, Hong- } \\
\text { Minh et al., 2001) }\end{array}$ \\
\hline
\end{tabular}




\section{Production strategy}

The theoretical base for this research is production strategy. This is also where the main theoretical contribution of this research lie. The research is positioned in the project based manufacturing area that is omitted in many traditional production strategy frameworks and the context of the research is house-building. The introduction and context, described in the previous two chapter, give this chapter a direction when presenting the theoretical base for this research. First an overview of the topic is given to get an understanding of what production strategy is. After that the dimensions of production strategy, that is relevant for this research, are accounted for.

\subsection{Overview and definition}

As previously mentioned, a production strategy has to exist to manage the different challenges the production function faces and help the company to make operational and strategic decisions so that the production function can meet market requirements in an effective and efficient way. When no production strategy exists the decisions may be arbitrary and unpredictable (Miltenburg, 2005).

Production strategy has been defined and interpreted by various researchers. Dangayach and Deshmukh (2001) compiled definitions of production strategy formulated by various authors. There are some variations in the definitions but all in all they are quite similar, in summary production strategy can be defined as:

Production strategy involves a pattern of decisions (Cox and Blackstone, 1998, Marucheck et al., 1990, Miltenburg, 2005, Slack and Lewis, 2011) to shape the long term capabilities of the production function (Slack and Lewis, 2011) to a competitive weapon (Marucheck et al., 1990, Swamidass and Newell, 1987) that supports the overall strategy of the firm (Hill and Hill, 2009, Slack and Lewis, 2011) for achieving business and corporate goals (Swamidass and Newell, 1987), through the reconciliation of market requirements and operations resources (Slack and Lewis, 2011).

Since 1969, when Skinner identified production as the missing link in corporate strategy (Skinner, 1969), the topic has evolved and research within many different thematic areas has been conducted. In their comprehensive literature review "Themes of study in manufacturing strategy literature" Chatha and Butt (2015) found that production strategy literature covers 11 major thematic areas, namely: production strategy components and paradigms, manufacturing capabilities, strategic choices, best practice, the strategy process, 
supply chain management, performance measurement, transnational comparisons, global manufacturing, environmental/green manufacturing and literature reviews. The thematic areas are described in more detail in Table 6.

Table 6 Thematic areas in production strategy literature

\begin{tabular}{|c|c|}
\hline Thematic area & Description \\
\hline $\begin{array}{l}\text { Components and } \\
\text { paradigms }\end{array}$ & $\begin{array}{l}\text { Include literature on the definition of production strategy, and components paradigms } \\
\text { and/or general articles on production strategy (Chatha and Butt, 2015, p. 618). }\end{array}$ \\
\hline Capabilities & $\begin{array}{l}\text { Include literature on competitive priorities, capabilities to realize competitive } \\
\text { priorities, resource based view, knowledge and learning, order winning criteria etc. } \\
\text { (Chatha and Butt, } 2015 \text { p. 619) }\end{array}$ \\
\hline Strategic choice & $\begin{array}{l}\text { Includes literature in structural and infrastructural choices. Structural choices include } \\
\text { capacity, process focus, technology choice, vertical integration and outsourcing and } \\
\text { facility/plant choice whereas infrastructural choice include planning and control, } \\
\text { organisation, human-resource management, purchasing, and product and/or process } \\
\text { development. (Chatha and Butt, } 2015 \text { p. 619) }\end{array}$ \\
\hline Best practices & $\begin{array}{l}\text { Include literature on lean and agile production, virtual manufacturing, mass } \\
\text { customisation, advanced manufacturing technology, JIT, etc. (Chatha and Butt, } 2015 \\
\text { p. 619) }\end{array}$ \\
\hline Strategy process & $\begin{array}{l}\text { Includes literature on strategy formulation and implementation, various approaches } \\
\text { and methods for formulating strategy are also included in this theme (Chatha and } \\
\text { Butt, } 2015 \text { p. 619) }\end{array}$ \\
\hline SCM & Includes literature on supply chain management. (Chatha and Butt, 2015 p. 619) \\
\hline $\begin{array}{l}\text { Performance } \\
\text { measurement }\end{array}$ & $\begin{array}{l}\text { Includes articles on measuring performance and design of measures (Chatha and } \\
\text { Butt, } 2015 \text { p. 619). }\end{array}$ \\
\hline $\begin{array}{l}\text { Transnational } \\
\text { comparisons }\end{array}$ & $\begin{array}{l}\text { Comparative studies between different countries or geographical regions pertaining } \\
\text { to production strategy practices are included in this theme (Chatha and Butt, } 2015 \mathrm{p} \text {. } \\
619) \text {. }\end{array}$ \\
\hline $\begin{array}{l}\text { Environmental } \\
\text { manufacturing }\end{array}$ & $\begin{array}{l}\text { Studies focussing on environmental factors are included in this theme (Chatha and } \\
\text { Butt, } 2015 \text { p. 619). }\end{array}$ \\
\hline $\begin{array}{l}\text { Global } \\
\text { manufacturing }\end{array}$ & $\begin{array}{l}\text { Because of the growing body of literature in international manufacturing, this theme } \\
\text { is identified (Chatha and Butt, } 2015 \text { p. 619). }\end{array}$ \\
\hline Literature reviews & $\begin{array}{l}\text { Includes studies on production strategy literature reviews (Chatha and Butt, } 2015 \mathrm{p} \text {. } \\
619 \text { ). }\end{array}$ \\
\hline
\end{tabular}

Closely related to research themes are dimensions that constitute the actual production strategy. Production strategy is often divided into two separate dimensions, content and process (Leong et al., 1990). Production strategy content focuses on the specific decisions that form the production system, and production strategy process focuses on how such decisions are formulated, implemented and used in an organizational setting (Fahey and Christensen, 1986). This can then be broken down in to number of additional dimensions (Mirzaei, 2015), as visualised Figure 7. The distinction between production strategy content and production strategy process is important to acknowledge in production strategy research since a discussion about the production strategy process is not relevant until the production strategy content is well defined (Rudberg, 2002). 


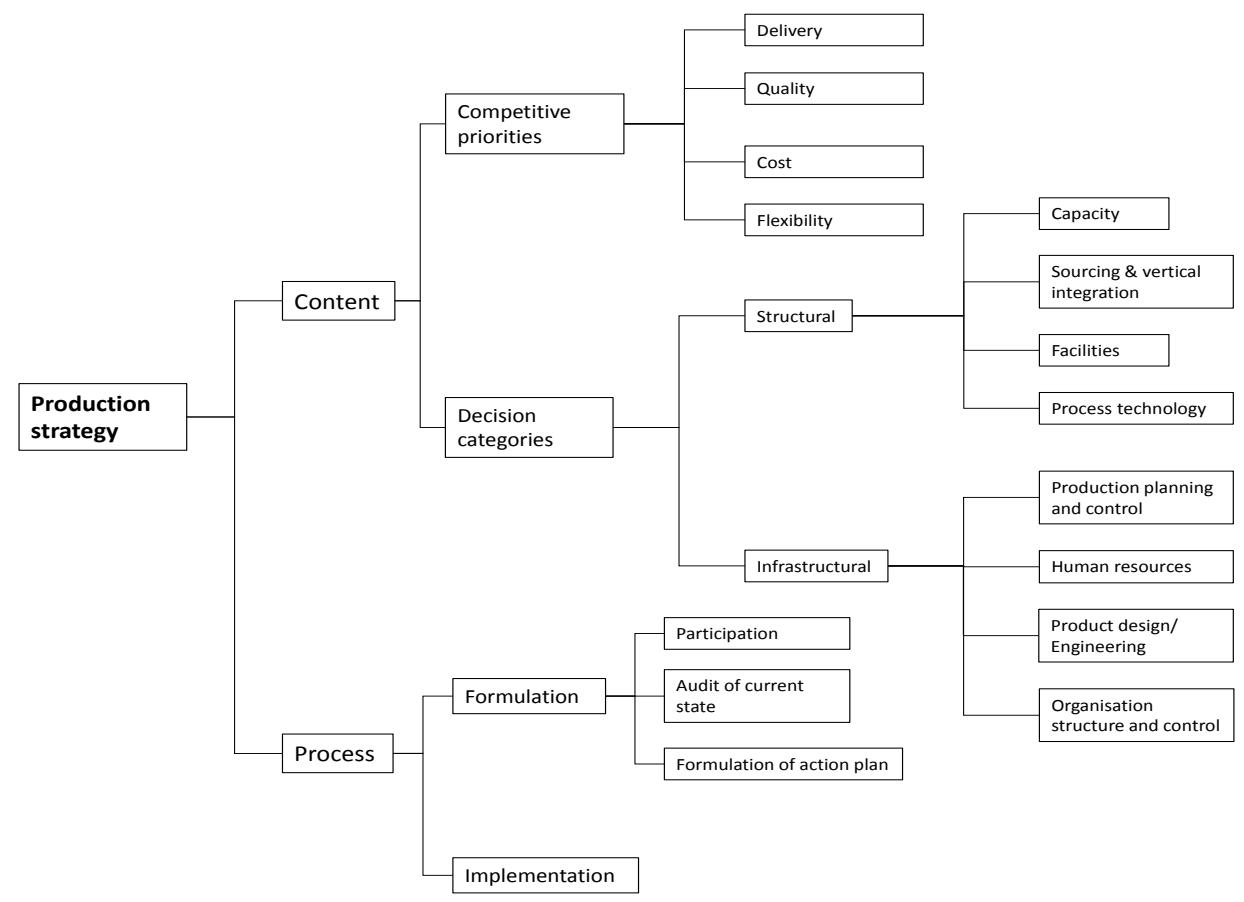

Figure 7 Production strategy dimensions, partly based on Mirzaei (2015, p 18).

The basic constructs of production strategy in a house-building context are no different than for traditional manufacturing. The production system must be designed so that it delivers manufacturing outputs at a level that supports the competitive priorities of the firm. Related to the process choice (Hill and Hill, 2009) it is also important in a house-building industry context to choose an appropriate production system that can meet the demands from the targeted market in an efficient way. It is when different dimensions in production strategy (Figure 7) are reviewed that the specific context of house-building show differences from, but also similarities with, traditional production strategy.

\subsection{Production strategy content}

Traditionally production strategy content is built around two groups; decision categories, that are of long term importance for the manufacturing function and competitive priorities, that are based on the market strategy of the firm (Leong et al., 1990). Decision categories and competitive priorities are vital terms in this research and thus described more in detail in the following.

\subsubsection{Competitive priorities}

The most basic route to competitive advantage and to outperform competitors on the market is to provide customers with superior value (Miltenburg, 2005). Another term that is used for competitive priorities is manufacturing outputs. The two terms describe the same thing but from different perspectives. The term manufacturing outputs is used when describing what the production function of the firm is able to deliver. The term competitive priorities 
is used when describing the market strategy of the firm in terms of what the targeted customers think is important. Thus, manufacturing outputs deal with potential performance while competitive priorities deal with importance (Safizadeh et al., 2000). Given this, one can say that from a production strategy perspective it is thus important that the production function of the firm delivers manufacturing outputs that support the competitive priorities of the company. The values created by a production system are called manufacturing outputs (Miltenburg, 2005). Competitive priorities are a set of goals for manufacturing (Leong et al., 1990) linking the market strategy with the production task, i.e. deciding in what areas of competition the firm wants to compete. Production strategy literature agrees on some of the competitive priorities while some are more author-specific. Table 7 provides an overview of competitive priorities that different authors consider important in a production strategy context.

Table 7 Examples of competitive priorities

\begin{tabular}{|l|l|l|l|}
\hline Leong et al. (1990) & Miltenburg (2005) & Hill and Hill (2009) & Slack and Lewis (2011) \\
\hline Quality & Quality & Quality conformance & Quality \\
\hline Delivery & Delivery & Delivery speed & Speed \\
\hline & & Delivery reliability & Dependability \\
\hline Cost & Cost & Price & Cost \\
\hline Flexibility & Flexibility & Product range & Flexibility \\
\hline & & Demand increase response & \\
\hline & & Colour range & \\
\hline & & Design & \\
\hline Innovativeness & Innovativeness & & \\
\hline & Performance & & \\
\hline & & Brand name* & \\
\hline & & Technical support* & \\
\hline & & After sales support* & \\
\hline
\end{tabular}

*Not production related.

The competitive priorities quality, delivery (speed and dependability), cost (level and dependability), and flexibility are mentioned (in one form or the other) by all authors. In this research focus is on these four "classical" competitive priorities (Hayes and Wheelwright, 1984, Leong et al., 1990, Ward et al., 1998). These competitive priorities are also described in Slack and Lewis (2011) as generic performance objectives that have meaning for all types of operations. These priorities specifically relates to the production function's basic task of satisfying customer requirements. For a company to be successful the link between market and production must be appreciated. If the customer require low price the production system must be designed to produce at low production cost, if delivery speed is most important to the customer focus should be on reducing lead times, etc.

The majority of production strategy research adopts trade-off reasoning when it comes to competitive priorities, meaning that focusing on improving the ability to deliver one manufacturing output will be at the expense of others (Hayes and Wheelwright, 1984, Hill and Hill, 2009, Miltenburg, 2005). Manufacturing outputs that have been found to be of contesting nature are for example quality and cost, cost and delivery lead times, and flexibility and cost efficiency (Hallgren et al., 2011). Trade-off reasoning thereby suggests 
that a certain production system cannot outperform its competitors in all areas of competition, and it is therefore important to design the production system so that it supports the market strategy of the firm. To highlight the fact that a firm and its production system cannot provide competitiveness along all competitive priorities, Hill and Hill (2009) introduces the terms order winner and order qualifier. To win orders a firm has to perform in parity, or better, than its competitors in one or more areas of competition. This will be done at the sacrifice of other areas. However, the other areas have to be at an acceptable level (order qualifying level), otherwise the customer will not consider the firm at all. It is important to recognise that order qualifiers are equally important as the order winners since a company cannot win an order if they do not even qualify on the market.

The concept of cumulative capabilities (Ferdows and Meyer, 1990) is an alternative perspective when discussing the relation between competitive priorities. It suggests that improvements of one competitive priority will facilitate improvements in other areas of competition. Even though the ultimate goal for the manufacturing function is to make the process cost efficient, first improvements to enhance quality must be made, then attention should be paid to improve dependability (on time delivery), then flexibility and not until a certain level within these areas has been reached direct attention can be paid to cost efficiency (Ferdows and Meyer, 1990).

At first, trade-off and cumulative capabilities seem to be competing rivals but Schmenner and Swink (1998) argue that the two are rather complements than rivals. This can be explained by that trade-off and cumulative capabilities are different in the sense that the trade-off is reflected in comparisons across plants at a given point in time, whereas cumulative capabilities are reflected in improvements within individual plants over time (Schmenner and Swink, 1998). From a production strategy perspective both comparison across plants and improvements over time are important aspects. However, when comparing different production systems with the purpose to visualise different production systems' relative strengths and weaknesses, the trade-off reasoning is argued to be valid.

Just as in more traditional manufacturing industries it is more or less impossible to design a production system for house-building that outperforms all other production systems in all areas of competition. Different production systems, using different levels of prefabrication, has pros and cons (Brege et al., 2014), and have strengths and weaknesses in different areas of competition. In traditional production strategy literature a set of competitive priorities are defined (Table 7), to link the market requirements to the task of the production function. To find out if the set of competitive priorities defined for traditional manufacturing are relevant in a house-building industry context a review of literature describing drivers and barriers for an increased the degree of off-site production are presented. The drivers and barriers can then be related to competitive priorities defined for traditional manufacturing and competitive priorities relevant in a house-building context can be identified. Table 8 summarises the identified drivers and barriers for off-site production. 
Table 8 Drivers and barriers for off-site production (Jonsson and Rudberg, 2014)

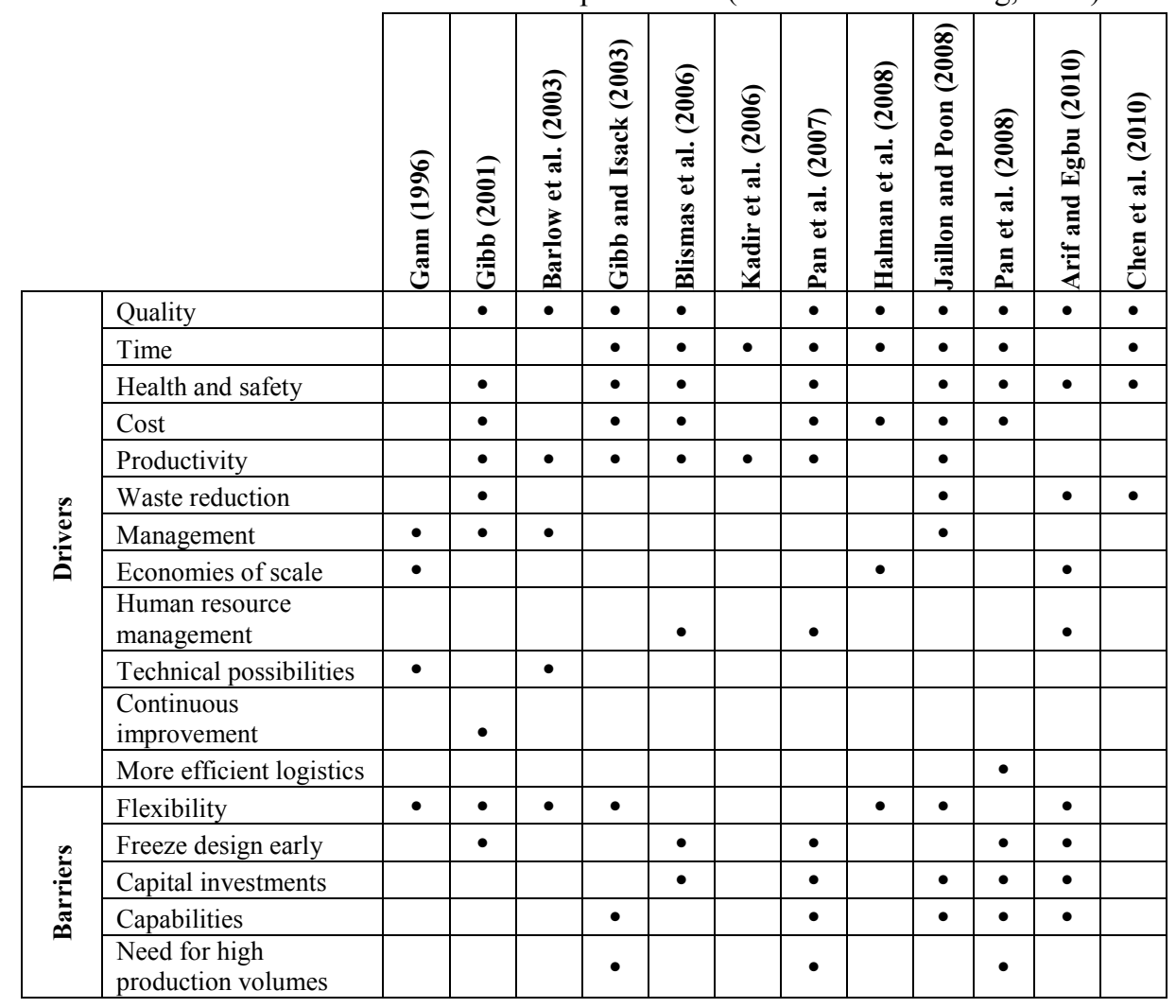

As can be seen in Table 8, the most frequently mentioned drivers for using off-site production in construction are: improved quality, shorter and/or more predictable production time, health and safety issues, lower and/or more predicable production cost and higher productivity. Other drivers for using off-site production are that it facilitates waste reduction, increased possibilities for economies of scale, better project management and human resource management, technical possibilities, continuous improvement, and more efficient logistics. Turning to the barriers in Table 8 , the most frequently mentioned ones are: reduced flexibility, the need to freeze design early, the level of capital investment, the different types of capabilities needed, and the need for high production volumes when investing in fixed assets for production.

If the drivers and barriers (Table 8) are compared to competitive priorities defined for traditional manufacturing industries (Table 7) there are some relations. For example, the drivers cost, productivity and waste reduction can all be clustered under the competitive priority cost. Technical possibilities and continuous improvements under quality. Time and more efficient logistics under delivery, and the barriers freeze the design early and a need for high production volumes can be related to flexibility. This indicates that competitive priorities used for traditional producing industries are also relevant in a house-building context. 


\subsubsection{Decision categories}

Decision categories are areas in which a company must make decisions that are of long term importance for the production function to be able to meet the market strategy of the firm (Leong et al., 1990). The decision categories can be categorized as structural or infrastructural. This distinction between structural decisions and infrastructural decisions was introduced by Hayes and Wheelwright (1984). The structural decisions are decisions that, have long-term impact on the production function, are difficult to reverse and undo when they are implemented, and typically requires substantial capital investments. The infrastructural decisions affect the people and systems that make the production function work.

The sets of decision categories differ somewhat between authors, but there is an essential agreement on the areas that really matters for the production strategy (Leong et al., 1990). Leong et al. (1990) made a comparison between decision categories and the result form that review is presented in Table 9. The decision categories presented in Miltenburg (2005) are also included as a complement to the sources published prior to the review performed by Leong et al. (1990). 


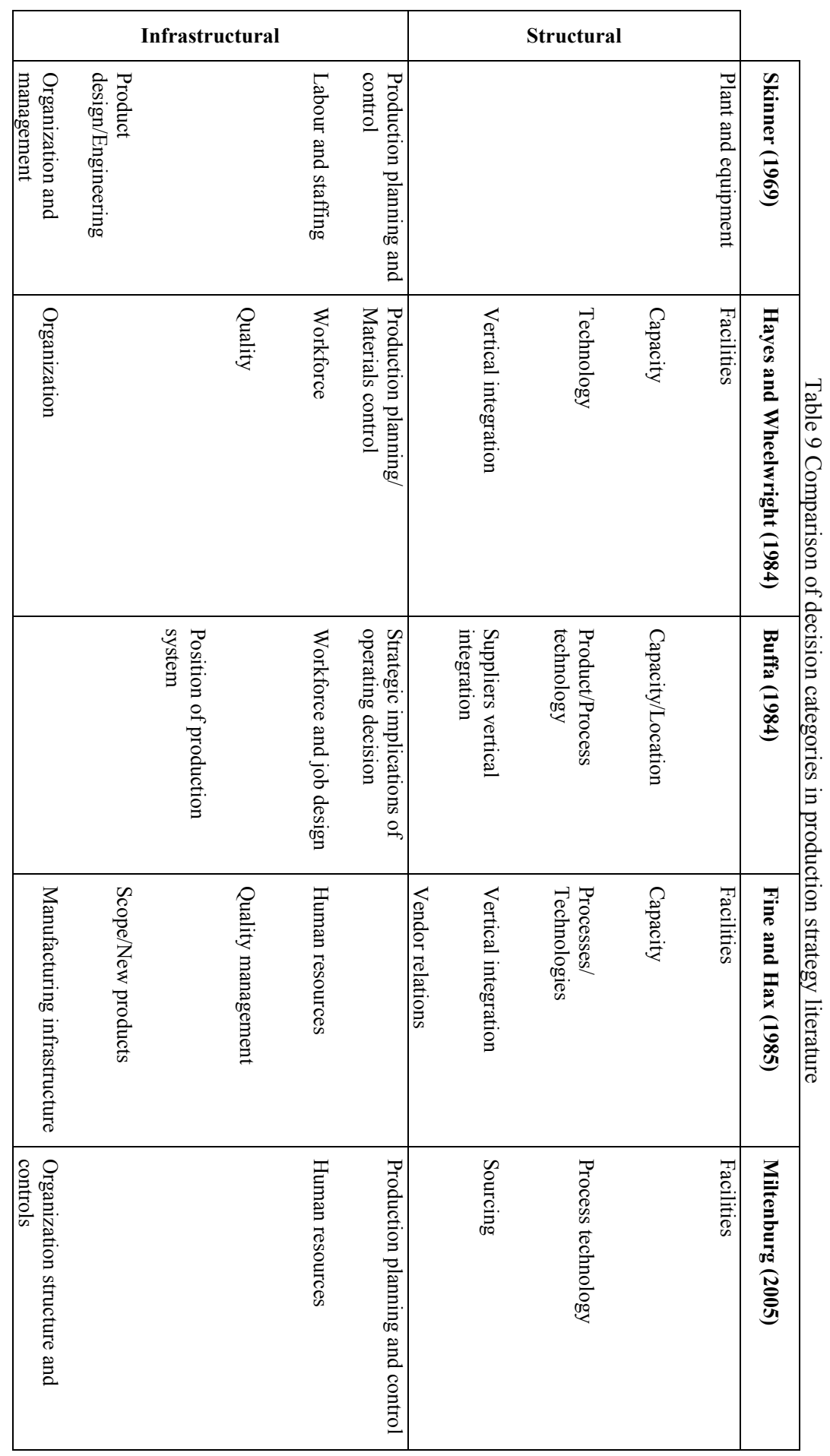


Worth mentioning is that Skinner (1969) includes the decision categories facilities, technology, capacity and vertical integration in the decision category plant and equipment. Skinner also includes quality in the decision category production planning and control.

Slack and Lewis (2011) defines four different decision categories, i.e. capacity, supply network, process technology and development and organisation. The reason for not including them in Table 9 is that they do not categorise the decision categories as purely structural or infrastructural. They mean that, in reality, all decision categories have both structural and infrastructural implications.

In summary there are in total eight decision categories that the literature agree upon. Four structural, i.e. capacity, sourcing and vertical integration, facilities, and process technology and four infrastructural, i.e. production planning and control, human recourses, product design/engineering, and organisation structure and control. These eight decision categories and examples of related decisions are presented in Table 10.

Table 10 Decision categories

\begin{tabular}{|c|c|c|}
\hline $\begin{array}{l}\text { Decision } \\
\text { category }\end{array}$ & Examples of decisions within each category & $\begin{array}{l}\text { Relevant } \\
\text { references }\end{array}$ \\
\hline Capacity & $\begin{array}{l}\text { How to deal with cyclical demand (holding excess capacity, } \\
\text { seasonal inventory, subcontracting). Whether to add capacity in } \\
\text { anticipation of future demand or in response to exciting demand. }\end{array}$ & $\begin{array}{l}\text { (Fine and Hax, } \\
\text { 1985) }\end{array}$ \\
\hline $\begin{array}{l}\text { Sourcing } \\
\text { and vertical } \\
\text { integration }\end{array}$ & $\begin{array}{l}\text { Make or buy decisions, i.e. amount of vertical integration. Control, } \\
\text { management and coordination of suppliers and parts of the value } \\
\text { system that the production system does not own, e.g. direction and } \\
\text { extent. Number of suppliers and type of relationship, e.g. purely } \\
\text { market-based or long term. }\end{array}$ & $\begin{array}{l}\text { (Miltenburg, 2005) } \\
\text { (Hayes and } \\
\text { Wheelwright, 1984) } \\
\text { (Slack and Lewis, } \\
\text { 2011) }\end{array}$ \\
\hline Facilities & $\begin{array}{l}\text { How to specialise or focus each facility, e.g. plant size, location } \\
\text { and capabilities, type and timing of changes, choice of equipment, } \\
\text { specialisation, etc. }\end{array}$ & $\begin{array}{l}\text { (Fine and Hax, } \\
\text { 1985) (Miltenburg, } \\
\text { 2005) (Hayes and } \\
\text { Wheelwright, 1984) }\end{array}$ \\
\hline $\begin{array}{l}\text { Process } \\
\text { technology }\end{array}$ & $\begin{array}{l}\text { Process choice, matching product characteristics with process } \\
\text { characteristics, degree of automation, layout etc. }\end{array}$ & $\begin{array}{l}\text { (Fine and Hax, } \\
\text { 1985) (Hayes and } \\
\text { Wheelwright, 1984) }\end{array}$ \\
\hline $\begin{array}{l}\text { Production } \\
\text { planning and } \\
\text { control }\end{array}$ & $\begin{array}{l}\text { Rules and systems that plan and control the flow of material, } \\
\text { production activities and support systems, e.g. maintenance, } \\
\text { centralisation. }\end{array}$ & (Miltenburg, 2005) \\
\hline $\begin{array}{l}\text { Human } \\
\text { recourses }\end{array}$ & $\begin{array}{l}\text { Comprises the company's human resource policies for the } \\
\text { production system at use. Decisions must be made regarding } \\
\text { training programs, skill level, incentive systems, employment } \\
\text { security, etc. }\end{array}$ & $\begin{array}{l}\text { (Fine and Hax, } \\
\text { 1985) (Miltenburg, } \\
\text { 2005) }\end{array}$ \\
\hline $\begin{array}{l}\text { Product } \\
\text { design/ } \\
\text { engineering }\end{array}$ & $\begin{array}{l}\text { Degree of product customisation. Frozen product design or } \\
\text { engineer to order design. The use of new technology (unproved by } \\
\text { competitors) or a "follow the leader" approach. }\end{array}$ & (Skinner, 1969) \\
\hline $\begin{array}{l}\text { Organisation } \\
\text { structure and } \\
\text { control }\end{array}$ & $\begin{array}{l}\text { Organisation structure, relationships between different groups of } \\
\text { employees, how are decisions made (top down or bottom up?), } \\
\text { culture, and systems for performance measurement }\end{array}$ & $\begin{array}{l}\text { (Miltenburg, 2005) } \\
\text { (Hayes and } \\
\text { Wheelwright, 1984) }\end{array}$ \\
\hline
\end{tabular}


According to Hill and Hill (2009) the most significant decisions manufacturing companies have to make are in the decision category process technology and concern customers, products and the process by which to make them. When choosing the appropriate way to produce its products, a company must choose between alternative production approaches and use the type of production system that best deliver manufacturing outputs that support the competitive priorities of the company. Factors that have to be taken into consideration are product characteristics, e.g. complexity and volumes, type of manufacturing process and the business implications of the product and process decisions. These factors are referred to as the process choice (Hill and Hill, 2009), i.e. choosing a production system that supports the competitive priorities of the firm (Rudberg, 2004). The process choice constitute the base in many production strategy frameworks developed for the manufacturing industry (see e.g. Hayes and Wheelwright, 1984, Hill and Hill, 2009, Miltenburg, 2005).

To categorize different production systems Hayes and Wheelwright (1979) introduced the product-process matrix. This matrix is used in various production strategy frameworks (see e.g. Hayes and Wheelwright, 1984, Hill and Hill, 2009, Miltenburg, 2005) to visualise the characteristics of different production systems and to facilitate the process choice. Separating the concept of the product life cycle and the process life cycle facilitates the understanding of the different strategic options, both marketing and manufacturing, available to the company. By using the dimension product life cycle, in terms of production volume and standardisation (low/low to high/high) on the x-axis, and the process life cycle (project, job shop, batch flow, line flow, and continuous processing) on the y-axis, correlations between the product structure and the process structure are visualised (Figure $8)$. 


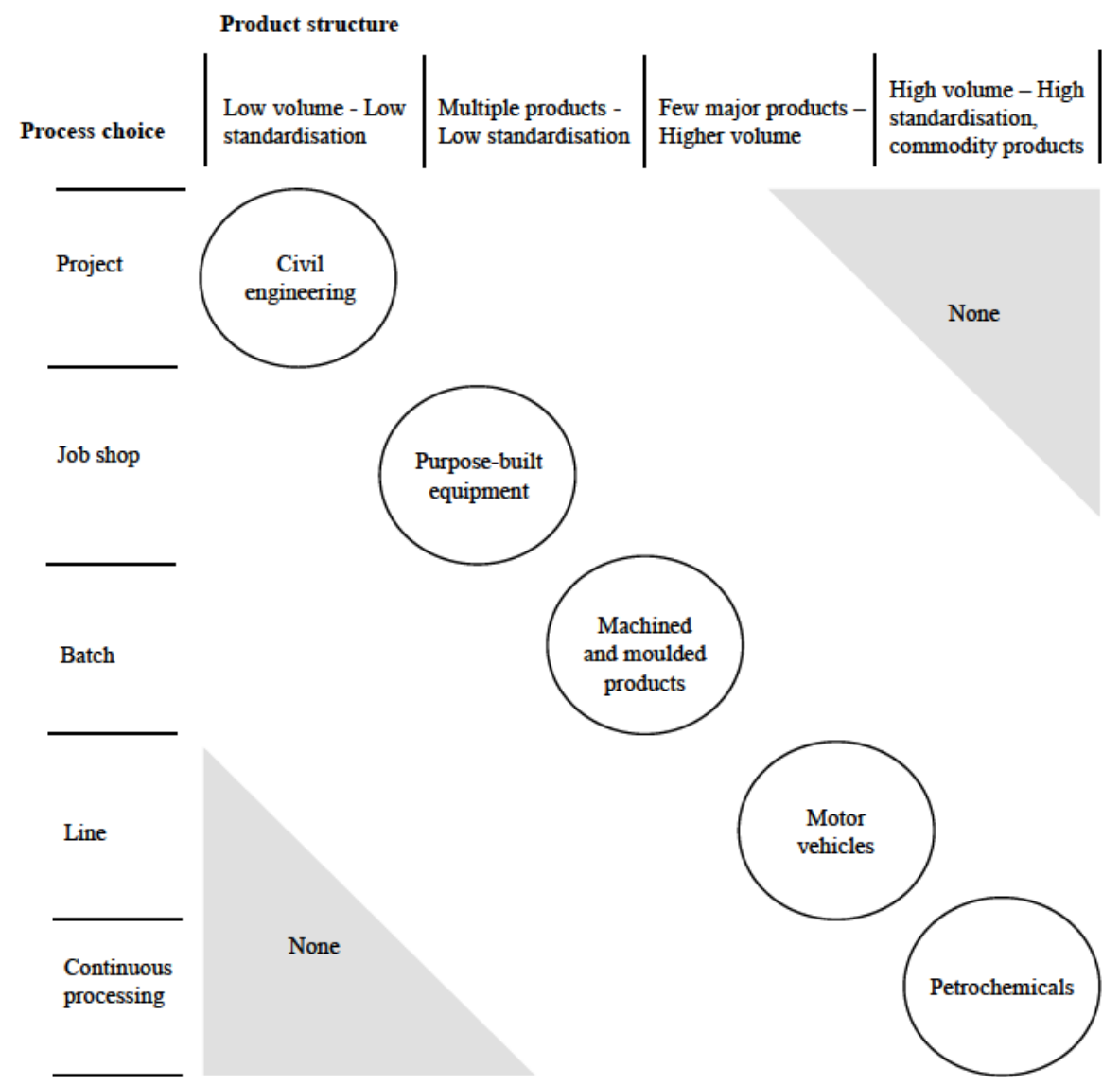

Figure 8 Product-process matrix adapted from (Hayes and Wheelwright, 1979) and (Hill and Hill, 2009)

To explain and clarify how the product and process are related to each other Hill and Hill (2009) give examples of typical products mapped in the matrix (Figure 8). The point is that different process structures are suitable for different product structures. If the market demands a customised product, the production system must be flexible, and in such cases a project or a job shop structure is preferable to a continuous flow or assembly line structure. If the market demands a standardised product, in high volumes and produced at a low cost, a continuous flow structure of the production system is the better choice. This way of matching the characteristics of the product with the characteristics of the process suggests that a production system should ideally be positioned along the diagonal in the product-process matrix. A position too far away from the diagonal should typically be avoided since there, in theory, is a risk that a production system designed that way will be outperformed by competitors better positioned in the matrix. However it is important to notice that even though Hayes and Wheelwright (1979) see the diagonal as the best position in the matrix where there is a good match between product and process characteristics, they do not necessarily predict ill fates for off-diagonal production systems. They merely 
counsel caution in such situations (Schmenner and Swink, 1998). Examples of effective production systems off the diagonal are innovative production systems such as Just-in-time (JIT) and Flexible manufacturing systems (FMS) that manage to handle a high product variety produced in low volumes using a relatively high degree of flow orientation (Miltenburg, 2005).

This research is concerned with house-building and, as stated in the introduction, focus is on the project part of the product-process matrix (Hayes and Wheelwright, 1979), see Figure 1. The project based organisation is an organisation where projects are the primary choice for production, innovation and competition. Project based organisations are widespread and exists in traditional industries, e.g. construction and shipbuilding, in industries regenerated through new technologies, e.g. aerospace and telecommunications, and other industries with hi-technology and high value capital goods (Hobday, 2000).

The strengths of project based organisations are the flexibility and the ability to respond to changing customer needs. However, all types of production systems for house-building are not designed to handle flexibility and customisation. The trade-off between flexibility and more productivity related outputs visualised in Table 8 shows that industrialised housebuilders are less flexible, hence have a harder time to offer a high degree of customisation than production systems using more traditional production methods on-site. This can be related to Lampel and Mintzberg (1996) stating that while some industries favour customisation and some foster standardisation, other industries, e.g. the construction industry, mix the two in their products and processes. To visualise this they presented standardisation versus customisation as the two extremes in a continuum of five different strategies (Lampel and Mintzberg, 1996). The full descriptions and definitions of the five strategies can be found in Lampel and Mintzberg (1996) but in summary: (1) Pure standardisation is a strategy where there are no distinction between different customers, hence the buyer has to adapt or else switch to another product. (2) Segmented standardisation is a strategy where firms respond to the need of different clusters of customers, but there is no distinction between different customers within each cluster. (3) Customised standardisation is a strategy where customised products are assembled from standardised components with integrated interfaces. (4) Tailored customisation is a strategy where the company presents a product prototype and then adapts or tailor it to customers' wishes or needs. (5) Pure customisation is a strategy where the customer's wishes penetrates deep into the design process and the products are truly made to order.

A project based organisation is also typically effective at integrating different types of knowledge and skills (Hobday, 2000). However project based manufacturing is weak when it comes to performing routine tasks, achieving economies of scale, coordinating crossproject resources, facilitating companywide technical solutions, and promoting organisation-wide learning. The project based organisation can also work against the wider interest of corporate strategy and goals (Hobday, 2000). However, all project based production is not exactly the same and within project based manufacturing there are some similarities, but also differences. Whitley (2006) identified two dimensions that separates different project based organisations. The first dimension review to what extent the 
company focus on developing unusual, sometime one-off products for varied and uncertain markets. The second dimension defines the extent to which the organisation is predictable and stable over projects. This indicated that different project based production systems are different and can be designed for different purposes, hence the process choice is equally important in a house-building context as it is for traditional manufacturing industries.

\subsection{Production strategy process}

The production strategy process involves the formulation and implementation of the production strategy. The process of production strategy formulation is concerned with how strategies are put together. Although strategies will vary from organisation to organisation they should attempt to reconcile market requirements with the production resources (Slack and Lewis, 2011). The process of production strategy implementation is concerned with implementing a new or revised production strategy.

In line with this Van de Ven (1992) categorise different models for development processes and gives examples of: strategic decision models, and strategic planning models. The strategic decision models concerns the process of coming to a decision for making a change, i.e. production strategy formulation. The models include: identification and a sense of need for change, develop awareness and understanding, develop tentative solutions and assessment of the tentative solutions, (see e.g. Cohen et al., 1972, Mintzberg et al., 1976). The strategic planning models cover how to make the change take place, i.e. production strategy implementation. These models include such steps as objectives setting, strategic programming for achieving the objectives, budgeting, monitoring and measuring progress towards the new strategy, but also establishing incentives to motivate goal achievement (Lorange, 1980). In the following production strategy formulation and production strategy implementation are described. After that a description of how the formulation and implementation can be assessed and evaluated are provided.

\subsubsection{Production strategy formulation}

The production strategy formulation processes traditionally, implicitly or explicitly, is described using the same steps. Platts and Gregory (1990) describes the formulation process in seven steps, i.e. strategy identification, environment analysis, resource analysis, gap analysis, strategic alternatives, strategic evaluation and finally strategic choice. These can, as an example, be related to the three steps of the formulation process described by Miltenburg (2005). In the first step the current status of the factory is defined. In this step the production system's position on the product-process matrix (Figure 8) is determined, i.e. strategy identification. The current level of capability for each decision category is also assessed, i.e. resource analysis. In the second step the future status of the factory is defined. This step includes a competitive analysis to determine the qualifying and order winning outputs that the production system must provide, and also determine what type of production systems that best meets the demands from the targeted market, i.e. environment analysis. In the third and final step it is decided how to get from the current status to the future desired status. If the first and second step show that the production system, currently in use, is the right type of production system to deliver the required manufacturing outputs, 
the production system can be improved by making adjustments within the different decision categories, but without changing the type of production system. If there is a mismatch between the production system in use and the competitive analysis performed in step two, the company must find a way to align the production system with market requirements, i.e. gap analysis. This can be done by changing to a better suited production system that meets the demands from the market in a better way (market based view) or by finding a different market segment that is better suited for the existing production system (resource based view), i.e. strategic alternatives, evaluation and choice.

The steps above answers the production strategy related questions why a production strategy need to be implemented/changed, and what has to change, i.e. what decisions have to be taken within each decision category, to be able to meet the market demands. A final step in the formulation process is suggested by Mills et al. (1995) and that is to formulate an action plan for implementation of the formulated production strategy. This is an important step in the production strategy process since it connects the formulation process with the implementation process in the production strategy process.

Besides following the process steps above other aspects are important to consider when evaluating a production strategy formulation process. Platts et al. (1996) presented a set of criteria for doing this, the criterias are presented in Table 11. It is important to recognise that the criterias, presented in Table 11, are to be used for evaluation of the actual formulation process and not for the resulting production strategy.

Table 11 Criteria's for evaluating the production strategy formulation process (Platts et al., 1996)

\begin{tabular}{|l|l|}
\hline Criteria & Description of the criteria \\
\hline Objectives & What is the objective of the process? \\
\hline $\begin{array}{l}\text { Effectiveness in } \\
\text { achieving the objectives }\end{array}$ & What measures are used to assess the performance of the process? \\
\hline Procedure & $\begin{array}{l}\text { Visibility: Is the existence of the process recognised within the different } \\
\text { functions of the company? } \\
\text { Formality: Is the process documented? }\end{array}$ \\
\hline Participation & $\begin{array}{l}\text { Involvement: Who is involved in the formulation process? } \\
\text { Communication: Are the result of the process communicated effectively to } \\
\text { the different functions within the company? }\end{array}$ \\
\hline Process management & How is the process managed? \\
\hline Adaptability & Is the process robust enough to adapt to new requirements? \\
\hline Potential for error & What methods are used to reduce the potential for errors? \\
\hline
\end{tabular}

\subsubsection{Production strategy implementation}

When the company know why they need a new or revised production strategy, what decisions they have to take to get from the current state to a desired future state, and have formulated a plan for how to implement the new/revised production strategy, it is time for the actual implementation.

The new production strategy is usually implemented through different change projects that are executed in a predetermined sequence by resources with the right competence for each change project (Miltenburg, 2005). However, production strategy implementation is a less 
structured and more behaviourally oriented process than formulation (Marucheck et al., 1990). In simple terms, the production strategy implementation is done using the input from the formulation process, taking decisions within the different decision categories so that the production strategy change according to what has been formulated (Miltenburg, 2005). As opposed to the formulation process, that typically takes a top-down approach (Marucheck et al., 1990), the implementation process involves different parts of the organisation to a larger extent and should be approached using a bottom-up approach. It is therefore important to communicate the results of the formulation process to all levels within the organisation and get acceptance of the new production strategy early on in the process to facilitate the implementation.

To initiate the implementation phase it is common to use a pilot study. The pilot study helps to reduce uncertainties regarding the new product and the process by which to produce it (Rodney Turner, 2005). To learn from a pilot study and improve the plan for implementation before committing to it in full can save a lot of time and money in the implementation phase. To really benefit from a pilot study feedback has to be documented and analysed and then used to revise the implementation plan, increasing the chances for a successful implementation. Kasunic (2004) presented a structured approach to a pilot study including five steps, i.e. plan and design, train personnel, support and monitor the pilot study, evaluate the pilot results, and make recommendations and improve.

After the pilot study is evaluated and the implementation plan has been revised the new strategy, product and or process can be fully implemented. The implementation process can be approached in different ways. Two approaches that are commonly used are the BigBang approach where everything is implemented at once or a phased in approach where the implementation is done incrementally over a longer period of time (Mabert et al., 2003). The Big-Bang approach usually results in the shortest implementation time but involves a higher degree of risk while a phased in approach reduces risk but takes longer time (Mabert et al., 2003). Which approach to use is dependent on the motive for making the change. For a proactive change made to stay competitive in the marketplace a phased in approach might be the preferred choice since there is no urgent need for change. For a crisis change that is more urgent a Big-bang approach might be a better approach.

Hayes and Wheelwright (1984) presents a number of aspects that should be taken into consideration when implementing a new production strategy. Organisational aspects are important, e.g. which parts/persons in the organisation should be included in the implementation process. The motivation for the change also has to be communicated to the whole organisation. As the implementation phase include all levels in the organisation to a larger extent than the formulation process, it is important to communicate what is changing and why. Finally the tools for executing the implementation must be defined. Besides these aspects, the keys to a successful implementation is leadership, the right skills and capabilities in the project team, to see the change as a first step to a desired goal and not as correcting something in the past, and finally get the whole organisation to feel included in the change process (Hayes and Wheelwright, 1984). 
In line with this, Marucheck et al. (1990) empirically derived a number of implementation issues that have to be considered: Involvement of lower levels is important since implementation involves lower levels of the organisation. Team approach, since it is important that different functions within the organisation is on board with the new production strategy and how to carry out the implementation. Corporate culture, that is the norms, values and informal beliefs held by the people in the organisation are important to consider (Marucheck et al., 1990). The corporate cultures are usually developed under an old set of business conditions and people are often unwilling to modify their decision patterns and activities so that they support the new production strategy (Marucheck et al., 1990). Consistency in implementation is mentioned as important. Regular meetings with lower level managers and staff to communicate, e.g. updates concerning the implementation plan and how well the strategic goals are being achieved is a way to achieve this. Top management commitment comes more natural in the formulation process (topdown approach) but it is equally important in the implementation process. Commitment from top management gives a sense of importance and provides impetus for a successful implementation.

The formulation and implementation processes described above follow a certain pattern of predetermined steps, following a specific sequence, from the start of the formulation process to the successful implementation of a new pre-determined production strategy. Mintzberg and Waters (1985) question the prescriptive approaches (formulation and implementation) described above and states that these "intended strategies" are affected along the implementation process. Some of the intended strategy is not realised, i.e. unrealised strategy, some of the intended strategy is realised, i.e. deliberate strategy and some ideas emerge during the implementation process, i.e. emergent strategy. All this put together ends up in a realised strategy, see Figure 9. Deliberate and emergent strategies can be seen as two ends of a continuum along which real-world strategies lie (Mintzberg and Waters, 1985).

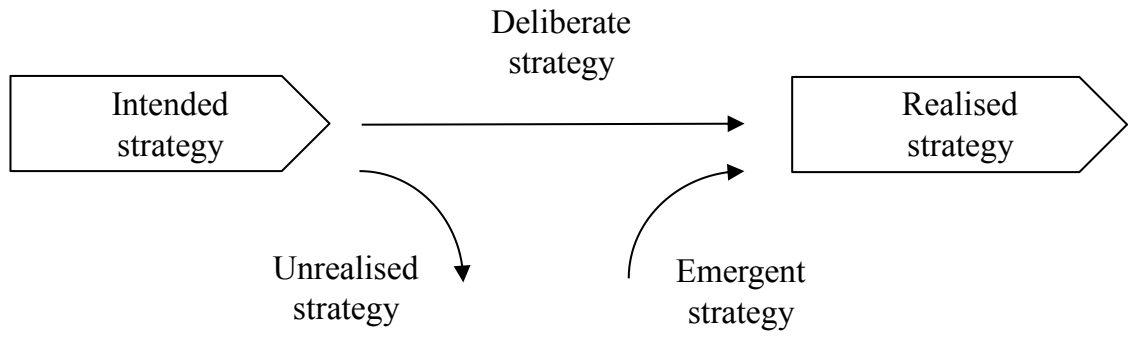

Figure 9 Different types of strategies (Mintzberg and Waters, 1985)

\subsection{Performance measurement}

When a company has decided in what market it want to compete and designed the production systems that supports the competitive priorities of the company, the 
performance of the production system has to be measured. In traditional production strategy literature the importance of performance measurement is emphasized. In Slack and Lewis (2011) it is stated that for a production strategy to be effective, performance must be measured and monitored. Hill and Hill (2009) point out that as part of the continuous reappraisal of production strategy decisions, performance must be monitored on a regular basis. In Miltenburg (2005) performance measures are used to make a competitive analysis of production systems, also indicating the importance of performance measurement from a production strategy perspective.

The focus on performance measurement has spread to many industries, including the construction industry (Bassioni et al., 2004). In construction various methods of measuring performance have been used. Robinson et al. (2005) investigated the utilization of performance measurement frameworks in leading U.K. construction firms and concluded that there were three methods that dominated the industry; the Balanced Scorecard, the European Foundation for Quality Management Excellence Model (EFQM Excellence Model) and the use of Key Performance Indicator (KPI) related systems.

When investigating potential systems for performance measurement in the construction industry used in a production strategy context it is important to make a distinction between performance management and performance measurement (Kagioglou et al., 2001). The performance management system is the process by which the company manages its performance. It is a process where feedback is provided from various levels in the organisation in order to manage the overall performance of the system. In a performance management system the strategy and policy of the organisation is in focus and deployed to all business processes, activities and personnel in the organisation. A performance measurement system is an information system and it constitutes the core process in the performance management system and provides the feedback that enables appropriate management decisions (Bititci et al., 1997).

In the construction industry, it is not uncommon that KPIs are used as a performance management system. That way of using KPIs has received some critique. Beatham et al. (2004) argues that most KPIs used in the construction industry are post event, lagging measures that do not provide the opportunity to make changes in the project that was measured. Bassioni et al. (2004) raises the issue that KPIs are used for benchmarking but do not give insight into the means of improving performance and therefore are of limited use for internal decision making. However, KPIs can be useful if they are used in the right way, i.e. as a tool in a performance management system. Both the balanced scorecard system (Kaplan and Norton, 1992) and the Excellence Models (EFQM, 2017) use KPIs to measure performance. This indicates that KPIs can also be useful as part of the production strategy development in a company, analysing different types of production systems ability to perform in different areas of competition. In the following section the use of KPIs in a construction production strategy context is described. In that context a production strategy framework (see e.g. Miltenburg, 2005) can be seen as the performance management system and the use of KPIs as the performance measurement system. 


\subsubsection{Key performance indicators (KPI)}

KPIs are frequently used to measure performance in the construction industry (Bassioni et al., 2004), and is the collective term for performance metrics in the construction industry (Beatham et al., 2004). Egan (1998) highlighted the importance of performance measurement and as a result of that report, the Construction Best Practice Programme (CBPP, 2002) launched KPIs for both project and organisational levels. The construction industry KPIs were first published in 1999, and are updated annually. Swan's and Kyng's (2004) report describe how to work with the KPIs defined by (CBPP, 2002) and list 10 headline KPIs, see Table 12.

Table 12 KPIs (Swan and Kyng, 2004)

\begin{tabular}{|l|l|}
\hline KPI & Description \\
\hline Construction Cost & Improvement of capital cost year on year. \\
\hline Construction Time & Improvement of time year on year \\
\hline Predictability Cost & $\begin{array}{l}\text { Actual cost against the cost predicted at } \\
\text { tender. }\end{array}$ \\
\hline Predictability Time & $\begin{array}{l}\text { Actual time against the time predicted at } \\
\text { tender }\end{array}$ \\
\hline $\begin{array}{l}\text { Client Satisfaction } \\
\text { Product }\end{array}$ & Client satisfaction with the delivered product \\
\hline $\begin{array}{l}\text { Client Satisfaction } \\
\text { Service }\end{array}$ & $\begin{array}{l}\text { Client satisfaction with the service provided } \\
\text { by the Project Team }\end{array}$ \\
\hline Defects & Impact of the defects of the final product \\
\hline Productivity & $\begin{array}{l}\text { Value added per person working on the } \\
\text { project }\end{array}$ \\
\hline Profitability & Profitability of the construction company \\
\hline Safety & Accident incident rate for the company \\
\hline
\end{tabular}

The headline KPIs in Swan and Kyng (2004) represent cost (level and dependability) and delivery (speed and dependability) and quality (defects), but flexibility is not represented by the headline KPIs. Beatham et al. (2004) describe the use of KPIs in the construction industry and give examples of organisations that have developed KPIs for the construction industry and describe them briefly. In Table 13, KPIs presented by some of the organisations are categorized under each of the KPIs: quality, delivery speed, delivery dependability, cost level and cost dependability. None of the organisations represented in Table 13 presented KPIs for measuring flexibility.

KPIs have been developed by other organisations than those presented in Table 13, for example The ACE consultants KPIs; Respect for people KPIs; Design Quality Indicator; Satisfaction of service KPIs (SoS KPIs), etc. The reason for not including these organisations in the list of potential KPIs are twofold. Firstly they consider areas that are a bit out of the scope for this research and secondly they are not publically available and the providing organisations charge a fee to get access to the KPIs. The KPIs from these organisations will therefore not be further investigated in this thesis. 


\begin{tabular}{|c|c|c|c|c|}
\hline 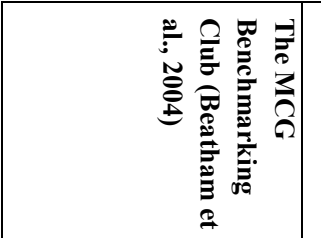 & 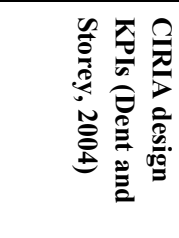 & 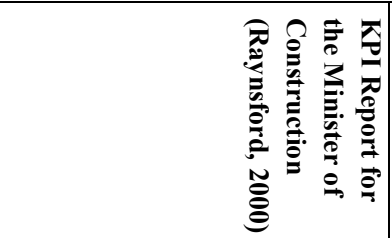 & 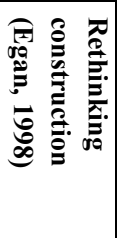 & \\
\hline 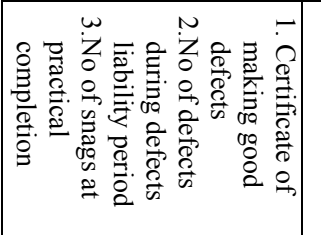 & ' & 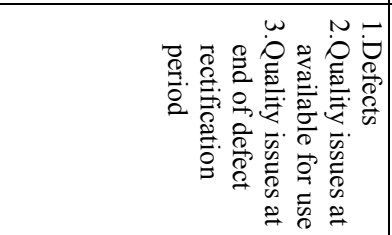 & 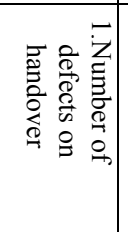 & 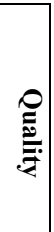 \\
\hline 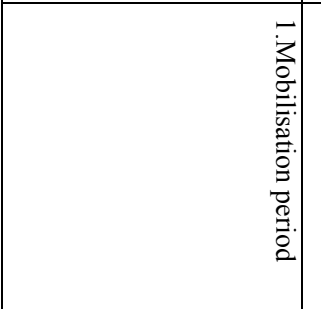 & 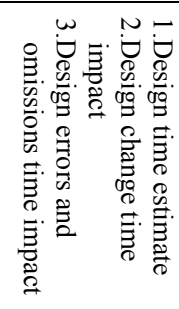 & 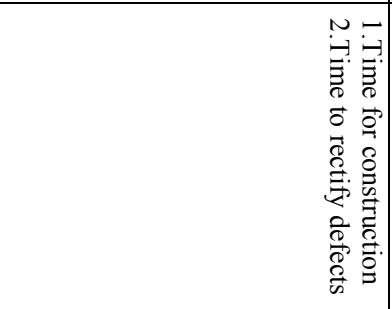 & 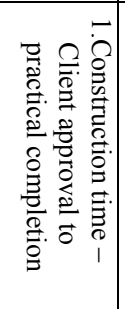 & 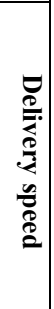 \\
\hline 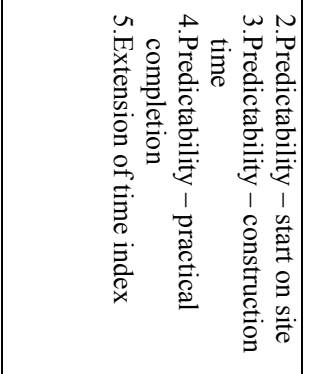 & & 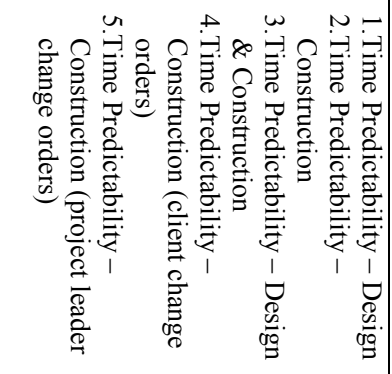 & 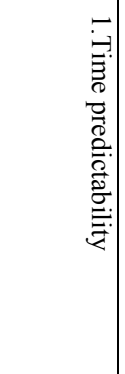 & 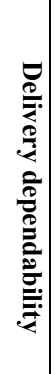 \\
\hline 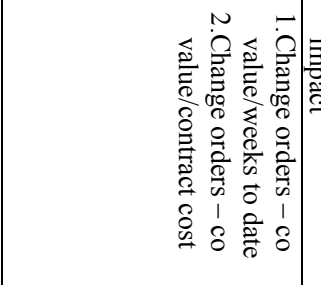 & 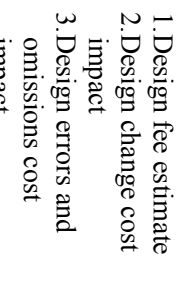 & 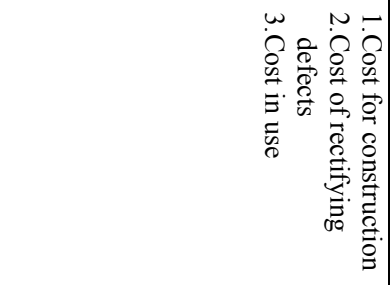 & 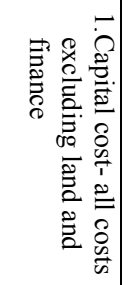 & $\begin{array}{l}0 \\
\frac{2}{2} \\
\frac{a}{2} \\
\frac{2}{2}\end{array}$ \\
\hline 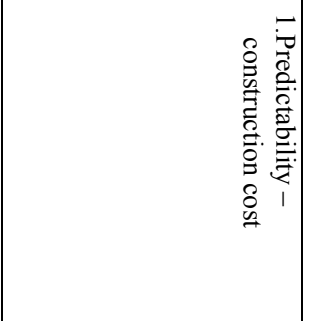 & & 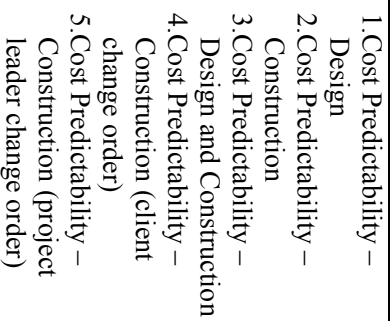 & 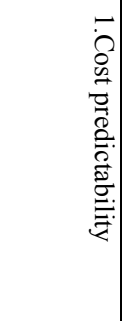 & 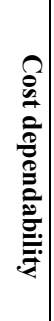 \\
\hline
\end{tabular}





\section{Research questions}

To be able to fulfil the purpose of this research, i.e. to extend the production strategy body of knowledge concerning project based production, in the context of house-building, four research questions have been formulated. In the following they are presented and motivated. Production strategy consists of a number of dimensions (Figure 7), and this research cover competitive priorities, product design and engineering, organisation structure and control, process technology, sourcing and vertical integration and the production strategy process (see Figure 11), in a house-building context. The motivation for including the dimensions that are considered in this research is described below and in chapter 5.

\subsection{Research question 1}

The process choice is central in production strategy frameworks developed for traditional manufacturing industries (see e.g. Hill and Hill, 2009, Miltenburg, 2005). To find the right match between product and process characteristics is important in a house-building context so that the production systems are effective in delivering manufacturing outputs to the targeted market segment. When reviewing literature that categorise different production systems for house-building, different aspects are treated such as, e.g. the design process (see e.g. Barlow and Ozaki, 2005, Gann, 1996, Segerstedt and Olofsson, 2010), and the degree of off-site assembly (see e.g. Doran and Giannakis, 2011, Kadir et al., 2006). What becomes apparent is that there is little focus on how a production system should be designed to perform in relation to market requirements. The important link between the market and the production function is thereby not explicitly addressed. In traditional production strategy literature the product-process matrix (Hayes and Wheelwright, 1979) is often used to facilitate the process choice. A corresponding classification matrix adapted to a housebuilding context that acknowledge different production systems' ability to meet customer demands, such as customisation, price, delivery and quality, would be useful to visualise the link between market requirements and the design of the production system The first research question is therefore related to categorisation of different production systems for production of multi-family houses.

RQ1: What aspects can be useful in a classification matrix, corresponding to the productprocess matrix (Hayes and Wheelwright, 1979), see Figure 8, contrasting different production systems for house-building? 


\subsection{Research question 2}

As stated above the link between the design of the production system and the ability to deliver manufacturing outputs is not explicitly treated in previous construction related research focusing on production system design (see e.g. Barlow et al., 2003, Segerstedt and Olofsson, 2010, Winch, 2003, Voordijk et al., 2006). Different production systems with different process characteristics can all be competitive given that the production function is aligned with the targeted market (Hayes and Wheelwright, 1984). To measure and compare different production systems' ability to perform in different areas of competition are important parts of production strategy, as indicated by the thematic areas presented in Chatha and Butt (2015). To be able to evaluate performance at a production strategy level, firstly valid and feasible measures have to be used and secondly, empirical data has to be accessed (Beatham et al., 2004). In the process of finding valid and feasible measures that can be used to measure performance, at a production strategic level, in a house-building context, it became apparent that most research that evaluate and compare production systems for house-building is based on qualitative estimations (see e.g. Arif and Egbu, 2010, Blismas et al., 2006, Gibb, 2001, Halman et al., 2008) rather than quantitative calculations. The second research question relates to the lack of publically available, welldefined and quantitative key performance indicators to measure performance at a production strategy level.

RQ2: Which competitive priorities are important to measure when evaluating different production systems on a production strategy level in a house-building context, and how can they be quantitatively be measured?

\subsection{Research question 3}

The next step in the research is towards investigating how the process choice affects other parts of the production system. This study investigates how the process choice, i.e. the design of the production system, affect information exchange in house-building projects. The reason for exploring information exchange relates to the fact that information exchange is an important part of any production system and in a context as complex as housebuilding, with long and fragmented supply chains and temporary project organisations, a wide range of information must be coordinated properly to ensure success of the project (Dainty et al., 2006). Previous research on information exchange in house-building typically consider traditional production methods on the construction site (see e.g. Dainty et al., 2006, Senaratne and Ruwanpura, 2016) or, in a few studies, industrialised housebuilding (see e.g. Bergström and Stehn, 2005, Persson et al., 2009) and do not appreciate differences between different types of production systems. The third research question relates to this by exploring how the design of the production system affects information exchange in a house-building context.

RQ3: How does the characteristics of the production system, i.e. the process choice, affect information exchange in a house-building context? 


\subsection{Research question 4}

The final part of the research study the process of formulating and implementing a revised production strategy for an industrialised house-builder. The process part of production strategy is not as well researched as the content part (Dangayach and Deshmukh, 2001) even though it has been given some more attention in recent years (Chatha and Butt, 2015). All companies need to change their strategies to deal with different courses of events in their surroundings. Change can be very challenging (Szulanski, 2000) and in a housebuilding context where culture impedes innovation, and emphasise the complexity and unique characteristics of each project, change can be even more challenging (Titus and Bröchner, 2005). In an industrialised house-building context there are circumstances that further contribute to this complexity, e.g. the fact that the house is produced in two different production processes, first in an off-site facility and after that production and assembly on site. To be successful in making a production strategy change in an industrialised housebuilding context the production strategy process must be structured and the company making the change must be aware of the context specific challenges. The fourth research question is related to this.

RQ4: How can a new production strategy be formulated and implemented in an industrialised house-building context and what challenges are important to consider in that process? 



\section{Research design}

This chapter describes the research design to give an overview of how the research has evolved through the decisions taken throughout the research process. The chapter describes the research process and methods used as transparent as possible for the reader to be able to judge the quality of the research. The chapter ends with a discussion around the research validity and reliability.

\subsection{Overview of the research process}

The research is divided into three separate but related studies. Study 1 covers process choice and performance measurement (RQ1 and RQ2), Study 2 takes a production strategy perspective on information exchange in house-building (RQ3), and Study 3 focuses on the formulation and implementation of production strategy in an industrialised house-building context (RQ4). An overview of the research process is visualised in Figure 10.

Study 1 includes three publications, Paper 1 in Construction Management and Economics, Paper 2 in Journal of Construction Engineering and Management and Paper 3 in Construction Innovation. Early versions of the papers have been presented at the EurOMA conferences in Amsterdam 2012, Dublin 2013 and Neuchâtel 2015 respectively. A working paper version of Paper 3 was also included in the licentiate thesis presented halfway through the PhD-studies, see Figure 10.

Study 2 resulted in an extended version of a conference paper presented at the EurOMA conference in Edinburgh 2017. The conference version of this paper had a page limitation, hence the paper has been extended in this publication to increase the quality of the paper.

The output of Study 3 also has its origin in a conference paper, presented at the EurOMA conference in Trondheim 2016. After the conference the paper has been re-written and shifted focus. The paper included in this thesis (Paper 5) is a working paper submitted to International Journal of Production Economics. 


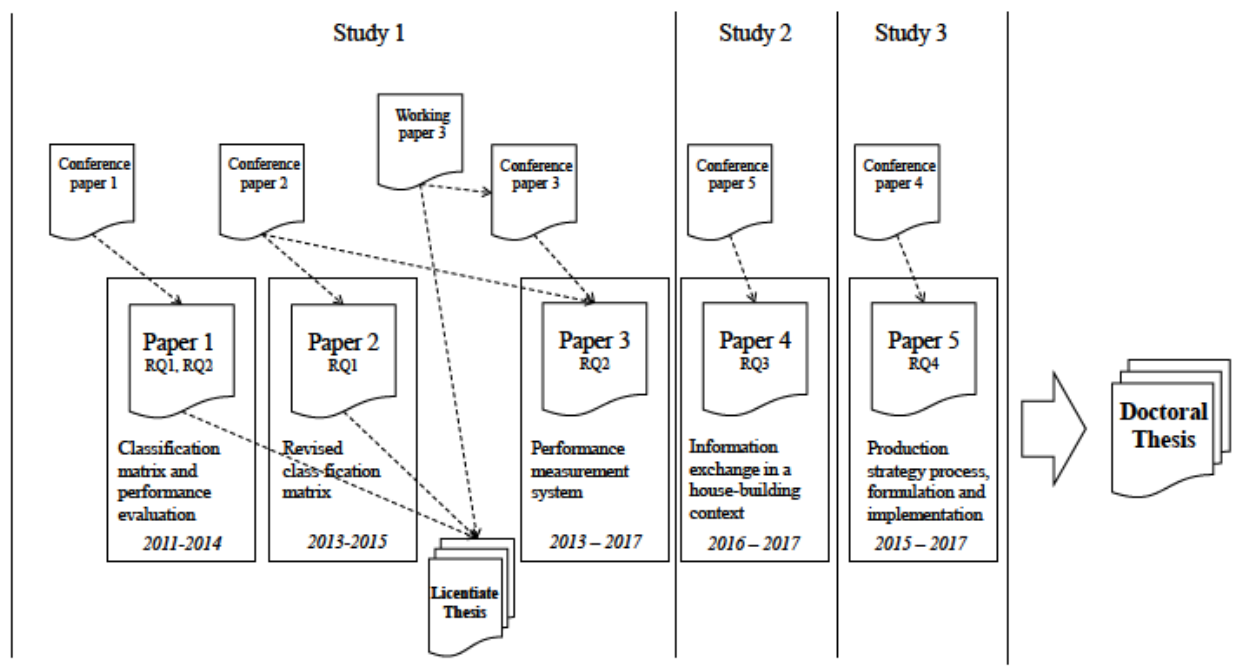

Figure 10 Overview of the research process

The four research questions (see chapter 4), all cover different dimensions of production strategy (see Figure 11) and different thematic areas. This research cover some, but far from all, dimensions of production strategy. The motivation for choosing what dimensions to include in the research was a combination of a conscious choice, pursuing research topics emerging in research process, and pursuing opportunities in terms of collaboration with the industry and access to empirical data.

The first study investigates how house-building production systems can be categorised (RQ1). This relates to the decision category process technology. The product design is also considered as one dimension in which different production systems can be categorised. This production strategy dimension was a natural starting point since one of the more important dimensions of production strategy is the so called process choice, hence a conscious choice.

The first study also included the second research question concerning performance measurement. The first part of that question investigates which competitive priorities that are important to measure in a house-building context. The second part of RQ2, i.e. how to measure the competitive priorities, is an important aspect of production strategy and a common thematic area in production strategy research (Chatha and Butt, 2015). The initial idea for this part of Stage 1 was to actually measure and compare performance between different types of production systems. When no measures could be found to measure performance at a strategic level, focus shifted towards developing a system for measuring performance, at a production strategy level, in a house-building context. Hence, this part of the research is an example of a research topic that emerged in the research process. The output of Study 1 was three journal papers (P1-P3) (Figure 11).

The second study and RQ3 takes a production strategy perspective on information exchange a house-building context. This is closely related to the decision category sourcing 
and vertical integration as the supply chain structure has a large effect on information exchange and the thematic area information sharing (Chatha and Butt, 2015). Information exchange is an important issue in a house-building context, hence including this topic was also a conscious choice. The output of Study 2 is a working paper based on a conference paper presented at the EurOMA conference in Edinburgh 2017 (P4) (Figure 11).

In the third study (RQ4) the process of formulating and implementing a production strategy for an industrialised house-builder is investigated, hence concerning the process dimension in production strategy literature. Access to an industrialised house-builder that had made a change in production strategy gave an opportunity to study a production strategy process (formulation and implementation) in an industrialised house-building context. When doing field research one can encounter both difficulties and opportunities when it comes to getting access to necessary data. In this study good access was provided, hence this was a combination of pursuing a relevant and interesting research topic, i.e. a conscious choice and the opportunity to get access to empirical data. The output of the Study 3 is a paper (P5) that has been submitted to the International Journal of Production Economics (Figure 11).

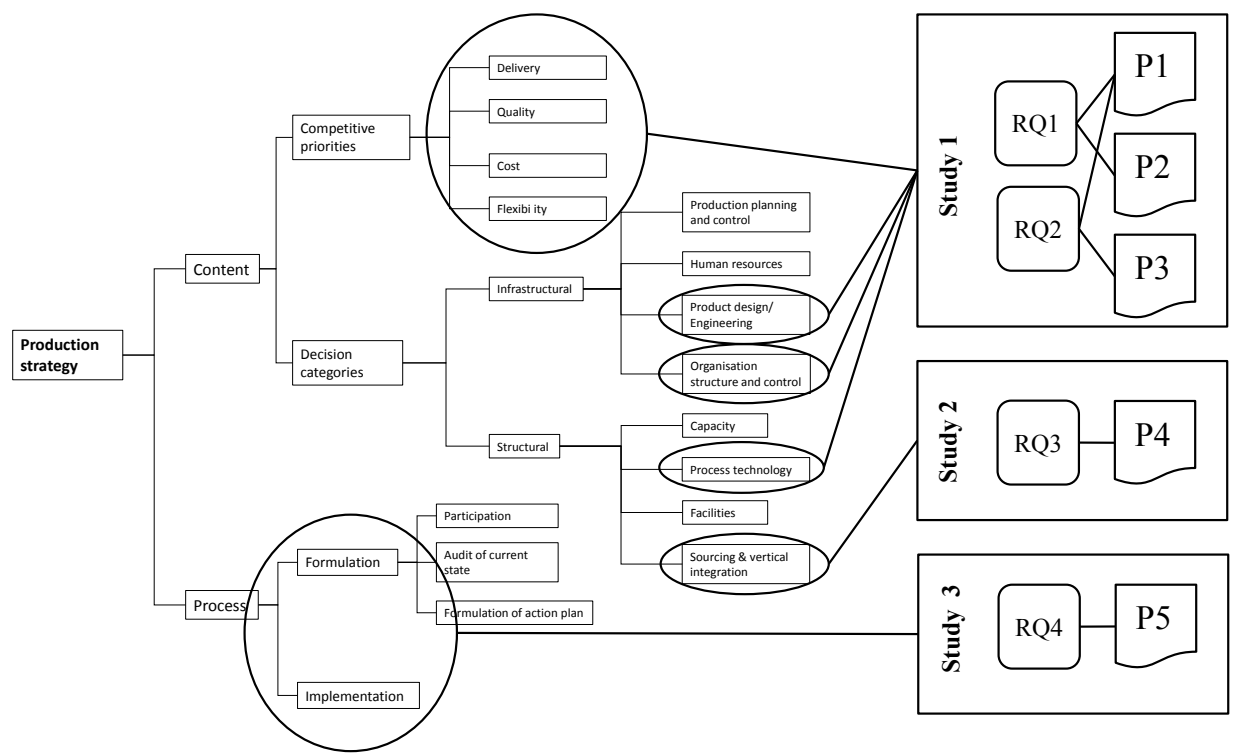

Figure 11 Production strategy dimensions considered in this thesis

In all studies empirical data from different types of production systems was collected and used both to test theoretical constructs and in a more inductive approach to explore different production strategy dimensions. In total eight different production systems were studied in the research. Production systems F and G have been forced to shut down whilst the other production systems were still active at the time they were studied. A description of the product and process characteristics of each production system is given in Table 14 . 
Table 14 Descriptions of production systems studied in this thesis

\begin{tabular}{|c|c|}
\hline Production & Description \\
\hline A & $\begin{array}{l}\text { Product characteristics: This production system only deliver one type of product and that } \\
\text { is tower block with four to eight floors. Each floor consists of standard apartments with one, } \\
\text { two three, or four rooms. The layout of each type of apartment is standardised. The layout } \\
\text { of the floors can be varied in terms of apartment combinations, however in one building each } \\
\text { floor must have the same layout. } \\
\text { Process characteristics: The production system use traditional production methods on-site } \\
\text { but since they have decided to standardise the product they have also standardised the } \\
\text { production process ta a large extent. The production process on-site also include production } \\
\text { of components that are traditionally prefabricated, e.g. balconies, joints and slabs. The } \\
\text { fabrication of these components on-site is used to transform waste, in terms of waiting time, } \\
\text { to value adding activities. }\end{array}$ \\
\hline B & $\begin{array}{l}\text { Product characteristics: This production system use a modular approach where } \\
\text { standardised components with integrated interfaces are combined to build the house. The } \\
\text { production system produces unique houses, designed by external architects, but within the } \\
\text { boundaries of the building system. They produce tower blocks, lamellar buildings and L- } \\
\text { shaped buildings with three to eight floors. } \\
\text { Process characteristics: This production system use prefabricated elements produced both } \\
\text { in their own off-site facility and by external suppliers. They also use prefabricated toilet pods } \\
\text { produced by an external supplier. The prefabricated concrete elements and toilet pods are } \\
\text { then assembled and completed on the construction site. }\end{array}$ \\
\hline $\mathrm{C}$ & $\begin{array}{l}\text { Product characteristics: This production system produces rental apartments and the } \\
\text { product is standardised to a large extent. They produce two types of buildings, a tower block } \\
\text { with four to eight floors and a lamellar building with four to six floors. The only choice } \\
\text { customer can affect is the exterior design where they can choose form three predetermined } \\
\text { designs so that the house can match the style of existing buildings in the surroundings. } \\
\text { Process characteristics: This production system do not own an off-site facility for } \\
\text { prefabrication. Instead they by prefabricated elements, façade elements and bathroom } \\
\text { modules from external suppliers. The elements are prefabricated to a relatively high degree } \\
\text { of completion off-site and assembled on the construction site to a house. }\end{array}$ \\
\hline D & $\begin{array}{l}\text { Product characteristics: This production system produce multifamily houses with two to } \\
\text { six floors and each house is designed based on customer needs. There are some limitations } \\
\text { in the design though, related to transport regulations of the prefabricated modules and the } \\
\text { fact that the product is based on technical solutions and a production process that are reused } \\
\text { to a great extent. Still, this production system offer a large degree of customisation. } \\
\text { Process characteristics: This production system produces modules to a high level of } \\
\text { completion off-site. The modules are complete with installations, floor, sealing, wallpaper, } \\
\text { wardrobes and kitchen when they leave the off-site facility. The only activities performed } \\
\text { on-site are assembly of the modules and finishing work. }\end{array}$ \\
\hline
\end{tabular}




\begin{tabular}{|c|c|}
\hline Production & Description \\
\hline E & $\begin{array}{l}\text { Product characteristics: This production system have gone through a strategic change } \\
\text { when it comes to the degree of product standardisation. Before the change they produced } \\
\text { only one type of house with limited possibilities for the customer to affect the design of the } \\
\text { houses. After the change they produced houses with a higher degree of customisation. Now } \\
\text { they can produce houses with two to four floors and there is no limit in terms of how many } \\
\text { apartments a house can contain. The apartment layouts are still standardised. } \\
\text { Process characteristics: This productions system prefabricate modules in an off-site facility } \\
\text { to a high level of completion. The modules are then transported to and assembled on the } \\
\text { construction site. The decreased degree of product standardisation affected the production } \\
\text { process on-site since it was in that process the increased product flexibility was taken care } \\
\text { of. In the off-site facility they still produce standardised modules to a high level of } \\
\text { completion. }\end{array}$ \\
\hline $\mathrm{F}$ & $\begin{array}{l}\text { Product characteristics: This production system produced houses up to eight floors and } \\
\text { was designed to be able to meet a high variety of customer demands. The prerequisite for } \\
\text { this was that customer choices were made early in the project development process. } \\
\text { Process characteristics: Elements, complete with installations and surfaces, was produced } \\
\text { in an off-site facility in three separate production lines producing ceiling/floor, walls, and } \\
\text { kitchens respectively. Stairways, balconies, bathrooms and roofs were also prefabricated but } \\
\text { bough from external suppliers. All the prefabricated elements were then transported to and } \\
\text { assembly on site in a large, temporary, weatherproof assembly hall. }\end{array}$ \\
\hline G & $\begin{array}{l}\text { Product characteristics: The production system could deliver multi-family houses up to } \\
\text { five floors. The approach when it came to customisation was to standardise the interior } \\
\text { design to a relatively large extent and customise the exterior to blend in to the surroundings. } \\
\text { Process characteristics: The building-system consisted of an independent structural frame } \\
\text { that carried the load and modules that were installed within the structural frame. The } \\
\text { modules were produced off-site to a high level of completion. Activities performed on-site } \\
\text { were, e.g. assembly, facades, complementary work with bathrooms and kitchen appliances. }\end{array}$ \\
\hline $\mathrm{H}$ & $\begin{array}{l}\text { Product characteristics: The houses are engineered to order and they offer a very high } \\
\text { degree of customisation. This production system can basically produce any type of house. } \\
\text { Process characteristics: This production system represent traditional production methods } \\
\text { on the construction site. The majority of the value adding activities are preformed on-site } \\
\text { and they use a small amount of pre-fabrication. }\end{array}$ \\
\hline
\end{tabular}

Each of the production systems described in Table 14 were studied in one or more studies in this research. The production systems are named differently in this thesis compared to what they are named in the different papers. Table 15 shows which production systems that took part in each respective study and paper and how the production systems are named in the papers. 
Table 15 Production systems included in the different studies and their names in the papers

\begin{tabular}{|c|c|c|c|c|c|}
\hline & \multicolumn{3}{|c|}{ Study 1} & Study 2 & Study 3 \\
\hline Production system & P1 & $\mathbf{P 2}$ & P3 & P4 & P5 \\
\hline $\mathrm{A}$ & & $\mathrm{A}$ & $\overline{\mathrm{A}}$ & & \\
\hline B & & B & B & B & \\
\hline $\mathrm{C}$ & & $\mathrm{C}$ & $\mathrm{C}$ & & \\
\hline $\bar{D}$ & Case MB & $\bar{D}$ & $\bar{D}$ & $\mathrm{D}$ & \\
\hline$E$ & & $E$ & $E$ & & Single case \\
\hline F & Case NVPA & & & & \\
\hline G & Case VPA & & & & \\
\hline$\overline{\mathrm{H}}$ & & & & $\mathrm{H}$ & \\
\hline
\end{tabular}

\subsection{Study 1: Process choice and performance measurement}

\subsubsection{Research design and process Study 1}

This first study is inspired by the production strategy framework developed by Miltenburg (2005). Figure 12 visualises the parts in Miltenburg's (2005) production strategy framework that consider the process choice (the left part of Figure 12) and performance evaluation (the right part of Figure 12).

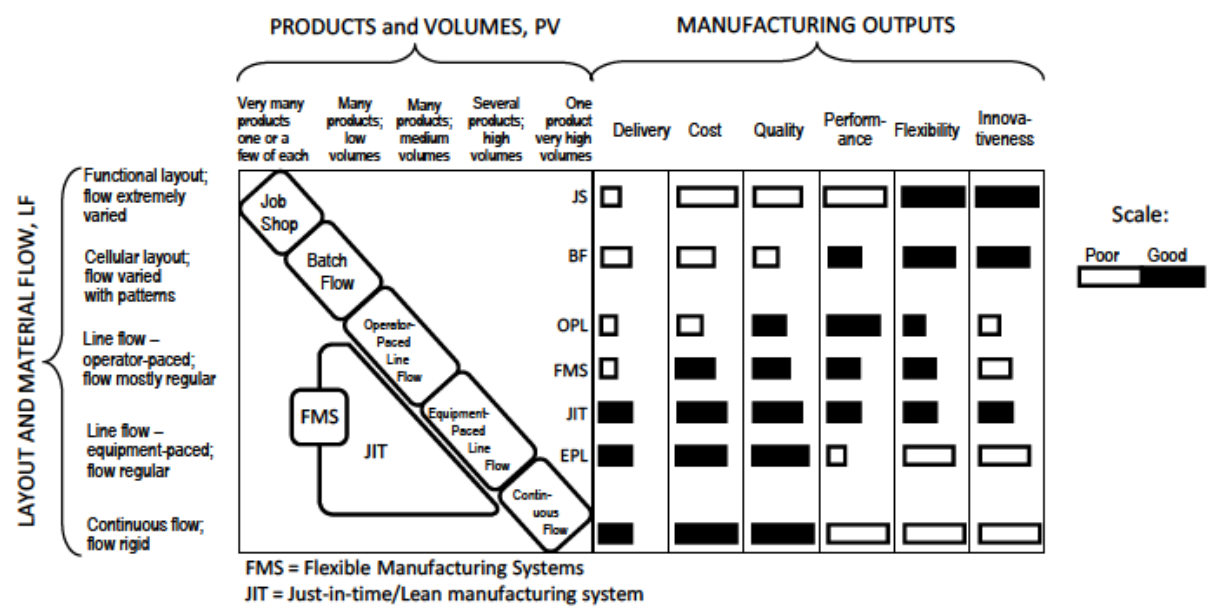

Figure 12 The two parts of Study 1 visualized in Miltenburg's (2005) production strategy framework

The research process for this study consists of three stages. In the first stage the theoretical constructs of this study were developed using literature and secondary data complemented with interviews regarding production system $\mathrm{D}, \mathrm{F}$ and $\mathrm{G}$. In the second stage the theoretical constructs were assessed using empirical data from five production systems (A, B, C, D and $\mathrm{E}$ ). In the third and final stage the theoretical constructs were refined and further developed using input from the empirical data, results from the literature review, and new empirical data collected through a second round of interviews. The research process for Study 1 is visualised in Figure 13. 


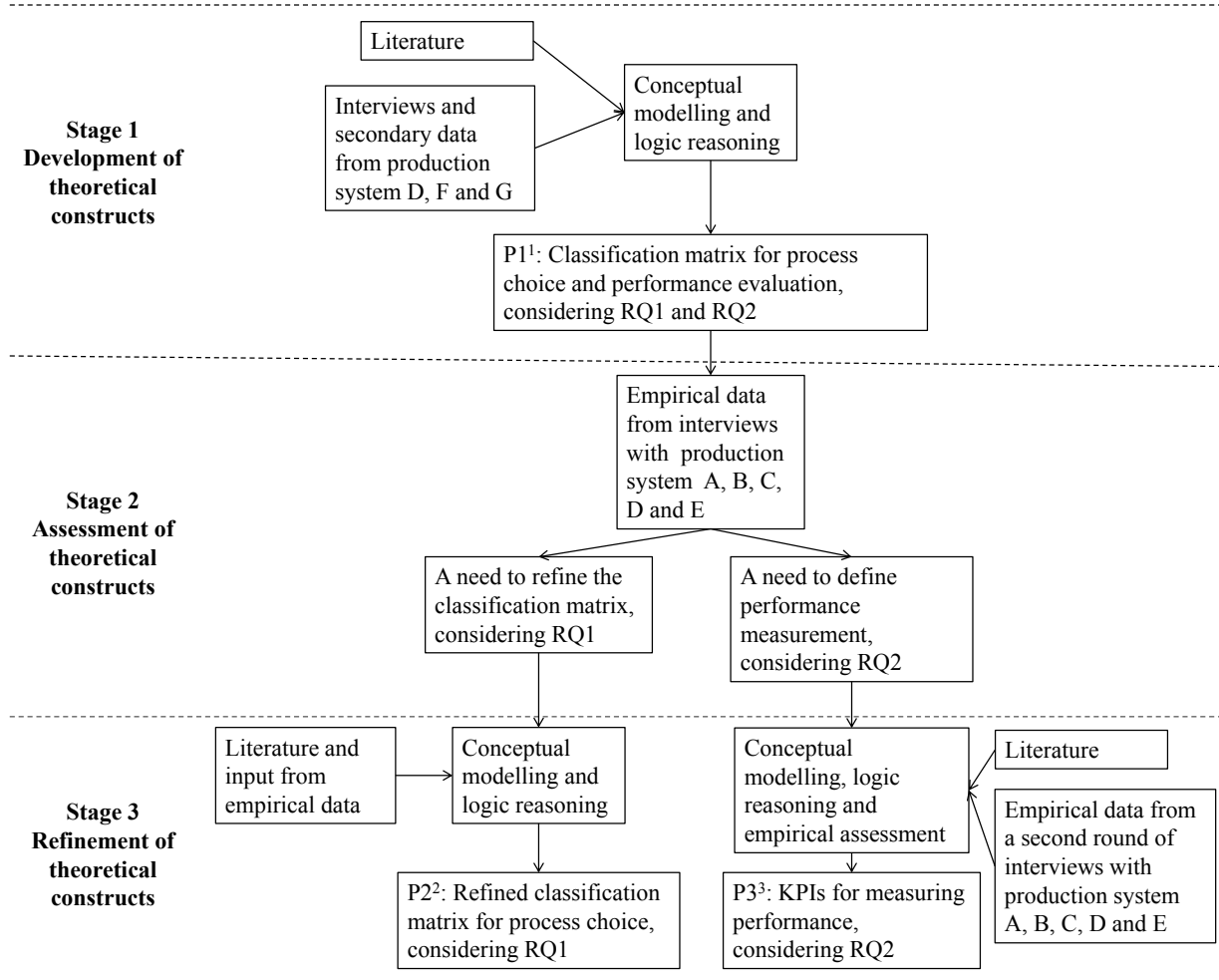

1 Paper 1, Classification of production systems for industrialized building: a production strategy perspective (Jonsson and Rudberg 2014)

2 Paper 2, Production system classification matrix: Matching product

standardisation and production system design (Jonsson and Rudberg 2015)

3 Paper 3, KPIs for measuring performance of productions systems for residential building: a production strategy perspective (Jonsson and Rudberg 2017)

Figure 13 Research process for Study 1

The literature review, secondary data, and interviews with persons involved in production systems D, F and G, were used in Stage 1 to develop a classification matrix corresponding to the left hand part of Figure 12. Production system D was also used in Stage 2 and 3. In Stage 1 the right hand part of Figure 12 was also considered by clustering drivers and barriers with off-site production and linking them to competitive priorities. The result from Stage 1 is a classification matrix for house-building production systems, offering the possibility to assess the relative ability of different types of production systems to perform in different areas of competition.

In the second stage the initial idea was to position a number of production systems in the classification matrix developed in Stage 1, and evaluate their ability to perform in different areas of competition. This resulted in a conference paper (conference paper 2 in Figure 10) but also a list of shortcomings with the classification matrix. What also became clear was 
that there is a lack of well-defined performance measurement systems developed to evaluate the ability of the production system to perform.

In stage 3 the classification matrix developed in Stage 1 was refined. One can question if it is motivated to include the first version of the classification matrix in this thesis when it has been revised and improved. The reason for including the first version and the results from Paper 1 is that the theoretical foundation for the final version is presented there and is still valid. The decision to revise it came from a more practical perspective, both academic and managerial. It was hard to map different production systems in the first version of the classification matrix and therefore hard for academics and practitioners to use.

To revise and improve the classification matrix, the input from production systems $\mathrm{D}, \mathrm{F}$, and $\mathrm{G}$, and the results from the literature review were used. The dimensions in the matrix were revised to be better adapted to a house-building context. The revised classification matrix was then tested using production systems A, B, C, D and E. Secondly a performance measurement system was developed. To do this a literature review were used to define KPIs for different areas of competition. The defined KPIs were then validated through empirical data from production systems A, B, C, D and E.

\subsubsection{Method Study 1}

The initial intention for this research was to use a deductive research approach. The logical conclusions (i.e. theoretical constructs) derived from theory (i.e. the literature review in Stage 1) were supposed to be tested in an empirical setting (Stage 2) and based on this present general conclusions. However, the test in an empirical setting did not match the theoretical constructs developed in Stage 1. This started an iterative approach to find new matching literature to extend the theoretical constructs defined prior to the empirical test. This is more in line with abductive reasoning (Kovács and Spens, 2005) where an iterative approach between theory and empirical data is used.

For the empirically grounded part of this research, Stage 2 and 3, case based research was chosen as the primary research method. In Stage 1 secondary data, in terms of already published papers, reports and publically available data about three production systems (D, $F$, and $G$ ) were used to validate the findings in Stage 1 . The secondary data was complemented with interviews with persons involved in the different production systems. To collect data from different sources increases the construct validity of the research and consistency of the findings (Yin, 2009).

Case studies have been argued to be a good method to follow-up previous research, e.g. survey-based research or, as in this instance, the results derived from a literature review and conceptual modelling (Karlsson, 2009). Case research can also be used for theory extension/refinement (Yin, 2009), as is the intention in this study. When selecting cases for theory building research each case should be selected to either predict similar results (literal replication), i.e. cases are chosen for statistical reasons (Eisenhardt, 1989), or to produce contrary results but for predictable reasons (theoretical replication) (Karlsson, 2009). In 
this study theoretical replication is used and a screening of the industrialised house-building sector in Sweden was made to identify suitable cases for the study. Persons involved in the industrialised house-building sector have been consulted, both from academia and from the industry, and this resulted in a list of potential candidates.

From this list, seven production systems were selected so that they would represent different types, in terms of product and process characteristics, thereby offering the possibility to expose differences and similarities between different production systems. All seven production systems accepted to participate in the research and they were visited for an initial interview and factory visit. After these initial visits, two of the production systems were left out since they did not produce whole buildings, but rather acted as supplier/subcontractor for another main contractor. The remaining five house-builders are production systems A-E presented in Table 14. The unit of analysis is thereby the production system and the cases in this study consist of different production systems for production of multifamily residences (whole buildings, being the main contractor).

The data for the five remaining cases was collected on two occasions. The first round of data was collected through on-site visits, review of company documents, and semistructured interviews with persons involved in developing and managing the different production systems. Each company visit consisted of a general presentation of the company and the production system (from their part), a presentation of the research project (from our part), a tour in the factory where the pre-fabrication of building components was performed and an interview with one or more persons, at management level, with knowledge about the production system. An interview protocol with predetermined questions was used in all interviews to be able to compare the different production systems and to ensure reliability. The questions in the interview protocol were related to four main topics:

- Background and general facts about the firm and their concept for producing multifamily residences

- The production system

- The product

- The market (clients and competitors)

The first bullet aims to give a general understanding of the firm and the related production system. The second and third give detailed information about the product and process characteristics respectively. The fourth bullet gives an indication on how the firm handles market requirements from clients and competitors. Information about the interviews is summarised in Table 16. 
Table 16 Summary of the interviews conducted in Stage 2 of Study 1

\begin{tabular}{|c|c|c|c|}
\hline $\begin{array}{l}\text { Production } \\
\text { system }\end{array}$ & $\begin{array}{l}\text { Function of key } \\
\text { informant(s) }\end{array}$ & $\begin{array}{l}\text { Topic of the } \\
\text { interview }\end{array}$ & Information about the interview \\
\hline$A^{*}$ & $\begin{array}{l}\text { Head of development, } \\
\text { responsible for } \\
\text { developing } \\
\text { technological platforms } \\
\text { for house-building }\end{array}$ & $\begin{array}{l}\text { The production } \\
\text { system, the } \\
\text { product, the } \\
\text { market, } \\
\text { coordination of } \\
\text { suppliers. }\end{array}$ & $\begin{array}{l}\text { Performed in person } \\
\text { The interview was performed by two } \\
\text { researchers. One was responsible for asking } \\
\text { the questions and the other for documentation. } \\
\text { Draft of interview documentation validated by } \\
\text { the respondent } \\
\text { Duration } 3 \text { hours }\end{array}$ \\
\hline B & $\begin{array}{l}\text { Four persons: } \\
\text { Head of development, } \\
\text { Responsible for } \\
\text { strategic planning, } \\
\text { Responsible for } \\
\text { logistics and purchase, } \\
\text { Supply chain manager }\end{array}$ & $\begin{array}{l}\text { The production } \\
\text { system, the } \\
\text { product, the } \\
\text { market, } \\
\text { coordination of } \\
\text { suppliers. }\end{array}$ & $\begin{array}{l}\text { Interview performed in person } \\
\text { The interview was performed by two } \\
\text { researchers. One was responsible for asking } \\
\text { the questions and the other for documentation. } \\
\text { Draft of interview documentation validated by } \\
\text { the respondent } \\
\text { One day including, interview, discussion, and } \\
\text { plant tour }\end{array}$ \\
\hline $\mathrm{C}^{*}$ & $\begin{array}{l}\text { Head of development, } \\
\text { responsible for } \\
\text { developing } \\
\text { technological platforms } \\
\text { for house-building }\end{array}$ & $\begin{array}{l}\text { The production } \\
\text { system, the } \\
\text { product, the } \\
\text { market, } \\
\text { coordination of } \\
\text { suppliers. }\end{array}$ & $\begin{array}{l}\text { Interview performed in person } \\
\text { The interview was performed by two } \\
\text { researchers. One was responsible for asking } \\
\text { the questions and the other for documentation. } \\
\text { Draft of interview documentation validated by } \\
\text { the respondent } \\
\text { Duration } 3 \text { hours }\end{array}$ \\
\hline $\mathrm{D}$ & $\begin{array}{l}\text { Three persons: } \\
\text { Head of } \\
\text { construction/design, } \\
\text { Head of purchase, } \\
\text { Business manager }\end{array}$ & $\begin{array}{l}\text { The production } \\
\text { system, the } \\
\text { product, the } \\
\text { market, } \\
\text { coordination of } \\
\text { suppliers. }\end{array}$ & $\begin{array}{l}\text { Separate interviews were performed with each } \\
\text { person. Two in person and one (business } \\
\text { manager) over the phone } \\
\text { Documented through notes taken by the } \\
\text { interviewer. } \\
\text { Draft of interview documentation validated by } \\
\text { the respondent. } \\
\text { Half a day including two interviews and plant } \\
\text { tour. The telephone interview was performed } \\
\text { separate duration } 90 \text { minutes. }\end{array}$ \\
\hline $\mathrm{E}$ & $\begin{array}{l}\text { Two persons: } \\
\text { Plant manager } \\
\text { Production manager } \\
\text { and head of production } \\
\text { system development }\end{array}$ & $\begin{array}{l}\text { The production } \\
\text { system, the } \\
\text { product, the } \\
\text { market, } \\
\text { coordination of } \\
\text { suppliers. }\end{array}$ & $\begin{array}{l}\text { Interview performed in person } \\
\text { The interview was performed by two } \\
\text { researchers. One was responsible for asking } \\
\text { the questions and the other for documentation. } \\
\text { Draft of interview documentation validated by } \\
\text { the respondent } \\
\text { Duration } 4 \text { hours, including interview, } \\
\text { discussion and plant tour }\end{array}$ \\
\hline
\end{tabular}

* Production system A and C are different production systems within the same company, data concerning both production systems were collected during the same interview session, with the same person.

After each visit the data was transcribed and compiled. If some information was missing additional interviews were performed by phone and e-mail.

The second round of data, concerning performance measurement, was collected through telephone interviews with the same production systems as in Stage 1, i.e. production systems A-E. An interview protocol with predetermined questions was sent to the respondents in advance so that they could prepare for the interview. Information about the interviews is summarised in Table 17. If the persons from the first round of interviews had good knowledge about performance measurement, they were interviewed in the second round of data gathering as well. In some cases other persons were contacted, on 
recommendation from earlier contacts within the production systems, since they had better knowledge about performance measurement.

Table 17 Summary of interviews conducted in Stage 3 of Study 1

\begin{tabular}{|c|c|c|c|}
\hline $\begin{array}{l}\text { Production } \\
\text { system }\end{array}$ & $\begin{array}{l}\text { Function of key } \\
\text { informant(s) }\end{array}$ & $\begin{array}{l}\text { Topic of the } \\
\text { interview }\end{array}$ & Information about the interview \\
\hline A* & $\begin{array}{l}\text { Head of development, } \\
\text { responsible for } \\
\text { developing } \\
\text { technological platforms } \\
\text { for house-building }\end{array}$ & $\begin{array}{l}\text { Performance } \\
\text { measurement }\end{array}$ & $\begin{array}{l}\text { Telephone interview } \\
\text { Questions sent to respondent in advance } \\
\text { Documented by taking notes during the } \\
\text { interview } \\
\text { Draft of interview documentation validated by } \\
\text { the respondent } \\
\text { Duration } 1 \text { hour }\end{array}$ \\
\hline B & $\begin{array}{l}\text { Two persons: } \\
\text { Head of development, } \\
\text { Head of production } \\
\text { support }\end{array}$ & $\begin{array}{l}\text { Performance } \\
\text { measurement }\end{array}$ & $\begin{array}{l}\text { Telephone interview } \\
\text { Questions sent to respondent in advance } \\
\text { Documented by taking notes during the } \\
\text { interview } \\
\text { Draft of interview documentation validated by } \\
\text { the respondent } \\
\text { Duration } 1 \text { hour }\end{array}$ \\
\hline $\mathrm{C}^{*}$ & $\begin{array}{l}\text { Head of development, } \\
\text { responsible for } \\
\text { developing } \\
\text { technological platforms } \\
\text { for house-building }\end{array}$ & $\begin{array}{l}\text { Performance } \\
\text { measurement }\end{array}$ & $\begin{array}{l}\text { Telephone interview } \\
\text { Questions sent to respondent in advance } \\
\text { Documented by taking notes during the } \\
\text { interview } \\
\text { Draft of interview documentation validated by } \\
\text { the respondent } \\
\text { Duration } 1 \text { hour }\end{array}$ \\
\hline $\mathrm{D}$ & Lean coordinator & $\begin{array}{l}\text { Performance } \\
\text { measurement }\end{array}$ & $\begin{array}{l}\text { Telephone interview } \\
\text { Questions sent to respondent in advance } \\
\text { Documented by taking notes during the } \\
\text { interview } \\
\text { Draft of interview documentation validated by } \\
\text { the respondent } \\
\text { Duration } 1.5 \text { hours }\end{array}$ \\
\hline $\mathrm{E}$ & $\begin{array}{l}\text { Production manager } \\
\text { and head of production } \\
\text { system development }\end{array}$ & $\begin{array}{l}\text { Performance } \\
\text { measurement }\end{array}$ & $\begin{array}{l}\text { Telephone interview } \\
\text { Questions sent to respondent in advance } \\
\text { Documented by taking notes during the } \\
\text { interview } \\
\text { Draft of interview documentation validated by } \\
\text { the respondent } \\
\text { Duration } 0,5 \text { hour }\end{array}$ \\
\hline
\end{tabular}

* Production system A and C are different production systems within the same company, data concerning both production systems were collected during the same interview session, with the same person.

The interview consisted of three parts. The first part focused on performance measurement in general within the house-building industry and more specifically on how they worked with performance measurement within their production system. This part of the interview gave insight in how the companies measured the ability of the production system to perform. The second part consisted of a discussion and validation of the theoretically defined metrics derived from performance measurement literature. This part of the interview was performed to be able to see if the derived metrics could be useful to the case companies. It was also used to refine some of the suggested metrics so that they would be in line with already established terms and metrics used in the house-building industry. The third part of the interview focused on the feasibility of the metrics, i.e. if the companies had access to all the necessary data to be able to use the suggested metrics. This part of the 
interview is important since, for any performance measurement system to be successful, the data should be easy to collect (Beatham et al., 2004). After collecting and compiling the data from the interviews, the drafts were sent back to the respondents for review to strengthen reliability.

\subsection{Study 2: Information exchange in house-building}

\subsubsection{Research design and process Study 2}

The study explores how the process choice affect information exchange in a haousebuilding context. The research process of this study is visualised in Figure 14.

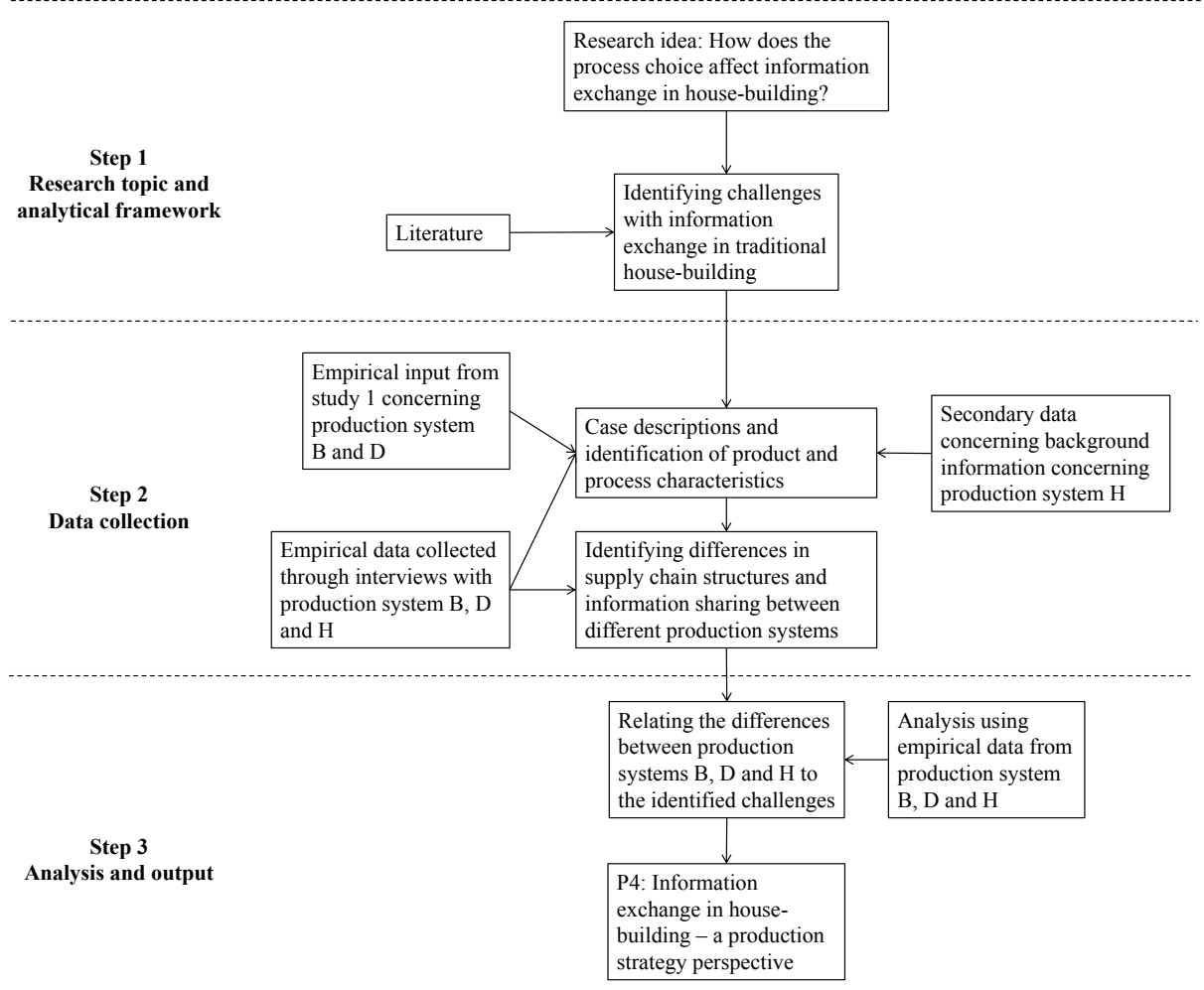

Figure 14 Research process Study 2

A literature review was used to identify challenges with information exchange in traditional house-building. Literature indicated that information exchange in a house-building context is complex and hard, and four main challenges were identified. In the second step empirical data was collected from production systems B, D and H, using semi-structured interviews, to see how the different types of production systems approached information exchange. Differences in supply chain structure and information exchange were analysed and related to the challenges. This was done to see to what extent the identified challenges with information exchange could be observed for different types of production systems. For the 
empirical part of Study 2 data were collected from three types of production systems. Two of the production systems (B and D) was also used in Study 1, hence some of the empirical data had already been collected and could be reused in this study. Production system $\mathrm{H}$ was new and represent the traditional way of producing houses, using no or very little off-site production. It was important to include that type of production system in this study since the challenges identified in the literature are related to traditional house-building on-site and including that type of production system gave the opportunity to validate the challenges, identified in academic literature, empirically.

\subsubsection{Method Study 2}

In this study interviews are used as the main source for collecting empirical data. The study is of exploratory nature to get an understanding of how the process choice affects information exchange in a house-building context. For this type of research, i.e. increasing understanding and/or generate propositions unstructured or semi-structured interviews are preferred to structured interviews that are more suitable for theory testing (DiCicco-Bloom and Crabtree, 2006). As mentioned above, three different production systems were used in this study to collect empirical data. The production systems were selected to represent different types so that a comparison of production systems, with different product and process characteristics, could be made. The empirical data was collected through semistructured interviews. Information about the interviews is summarised in Table 18.

Table 18 Summary of interviews conducted in Study 2

\begin{tabular}{|c|c|c|c|}
\hline $\begin{array}{l}\text { Production } \\
\text { system }\end{array}$ & $\begin{array}{l}\text { Function of } \\
\text { key informant }\end{array}$ & $\begin{array}{l}\text { Topic of the } \\
\text { interview }\end{array}$ & Information about the interview \\
\hline $\mathrm{B}$ & $\begin{array}{l}\text { Contract } \\
\text { manager and } \\
\text { head of } \\
\text { development }\end{array}$ & $\begin{array}{l}\text { Supply chain } \\
\text { structure and } \\
\text { information exchange }\end{array}$ & $\begin{array}{l}\text { Interview performed over telephone. } \\
\text { Documented through notes taken by the } \\
\text { interviewer. } \\
\text { Draft of interview documentation validated by } \\
\text { the respondent } \\
\text { Duration } 90 \text { minutes }\end{array}$ \\
\hline $\mathrm{D}$ & Project leader & Information exchange & $\begin{array}{l}\text { Interview performed over telephone. } \\
\text { Documented through notes taken by the } \\
\text { interviewer. } \\
\text { Draft of interview documentation validated by } \\
\text { the respondent } \\
\text { Duration } 90 \text { minutes }\end{array}$ \\
\hline $\mathrm{D}$ & $\begin{array}{l}\text { Head of } \\
\text { logistics and } \\
\text { SCM }\end{array}$ & $\begin{array}{l}\text { Mainly supply chain } \\
\text { structure and some } \\
\text { complementary } \\
\text { information about } \\
\text { information exchange } \\
\text { in the supply chain. }\end{array}$ & $\begin{array}{l}\text { Interview performed over telephone. } \\
\text { Documented through notes taken by the } \\
\text { interviewer. } \\
\text { Draft of interview documentation validated by } \\
\text { the respondent } \\
\text { Duration } 90 \text { minutes }\end{array}$ \\
\hline $\mathrm{H}$ & $\begin{array}{l}\text { Purchase } \\
\text { manager at } \\
\text { regional level. }\end{array}$ & $\begin{array}{l}\text { Supply chain } \\
\text { structure and } \\
\text { information exchange }\end{array}$ & $\begin{array}{l}\text { Interview performed in person } \\
\text { Documented through notes taken by the } \\
\text { interviewer. } \\
\text { Draft of interview documentation validated by } \\
\text { the respondent. } \\
\text { Duration } 2,5 \text { hours }\end{array}$ \\
\hline
\end{tabular}

For production system D two interviews were performed. The first interview was performed with a project leader and that interview focused mainly on information exchange. The second interview was performed with the head of logistics and focused 
mainly on supply chain structure and supply chain management. Some additional/clarifying questions were asked through e-mail correspondence. Notes were taken during the interviews and the documentation from each interview was sent to and validated by the corresponding persons.

For production system B only one interview was performed, the reason for that was that the corresponding person had good insight in both supply chain structure and information exchange. The interviewed person is contract manager and head of development and had long experience of developing and managing production system $\mathrm{B}$. The interview was performed over the phone, approximately 90 minutes, and the notes from the interview was sent to the corresponding person for verification.

For production system $\mathrm{H}$ the interview was performed in person. Since this was the first collaboration with this house-builder some more time, approximately 2,5 hours, were spent on this interview. The person interviewed is head of purchase within one of the housebuilder's districts in Sweden and also the link between the district and the purchase organisation on a national level. The interviewed person had good knowledge mainly about the supply chain structure but also about information exchange, hence only one person from production system $\mathrm{H}$ was interviewed.

The interviews performed with production system B and D are in line with the description of short case study interviews whilst the interview with production system $\mathrm{H}$ is more in line with a prolonged case study interview (Yin, 2013). This was a suitable approach since the interview with production system $\mathrm{B}$ and $\mathrm{D}$ could be more focused on the topics at hand due to previous collaborations whilst the interview with production system $\mathrm{H}$ had to start broader and then be narrowed down to the topics relevant for this study.

\subsection{Study 3: Production strategy process}

\subsubsection{Research design and process Study 3}

The idea for this study came during Study 1 in our collaboration with production system E. They announced that they were planning a change in strategy by targeting a new market closer to the city-centres. To be able to do that they had to make the design of the product more flexible. This change in market strategy had an effect on the production function and in Study 3 the production strategy process, i.e. the process of formulating and implementing the new production strategy was studied.

This study was a bit different form Study 1 and Study 2 in the sense that empirical data was used to describe the process and then evaluated using theory, compared to using the empirical data to test theoretical constructs. This is more in line with an inductive approach where specific observations, interviews, etc., were made and then used to develop broader generalisations. Data was collected using different sources of information. Semi-structured interviews were conducted with persons holding different positions in the production system. Observations on-site and in the off-site facility were made to get an understanding of the production process. Access to company documents related to the change in 
production strategy were also provided. The collected data was used to describe the production strategy process (formulation and implementation) and the production strategy process was then evaluated using literature. The research process for this study is visualised in Figure 15.

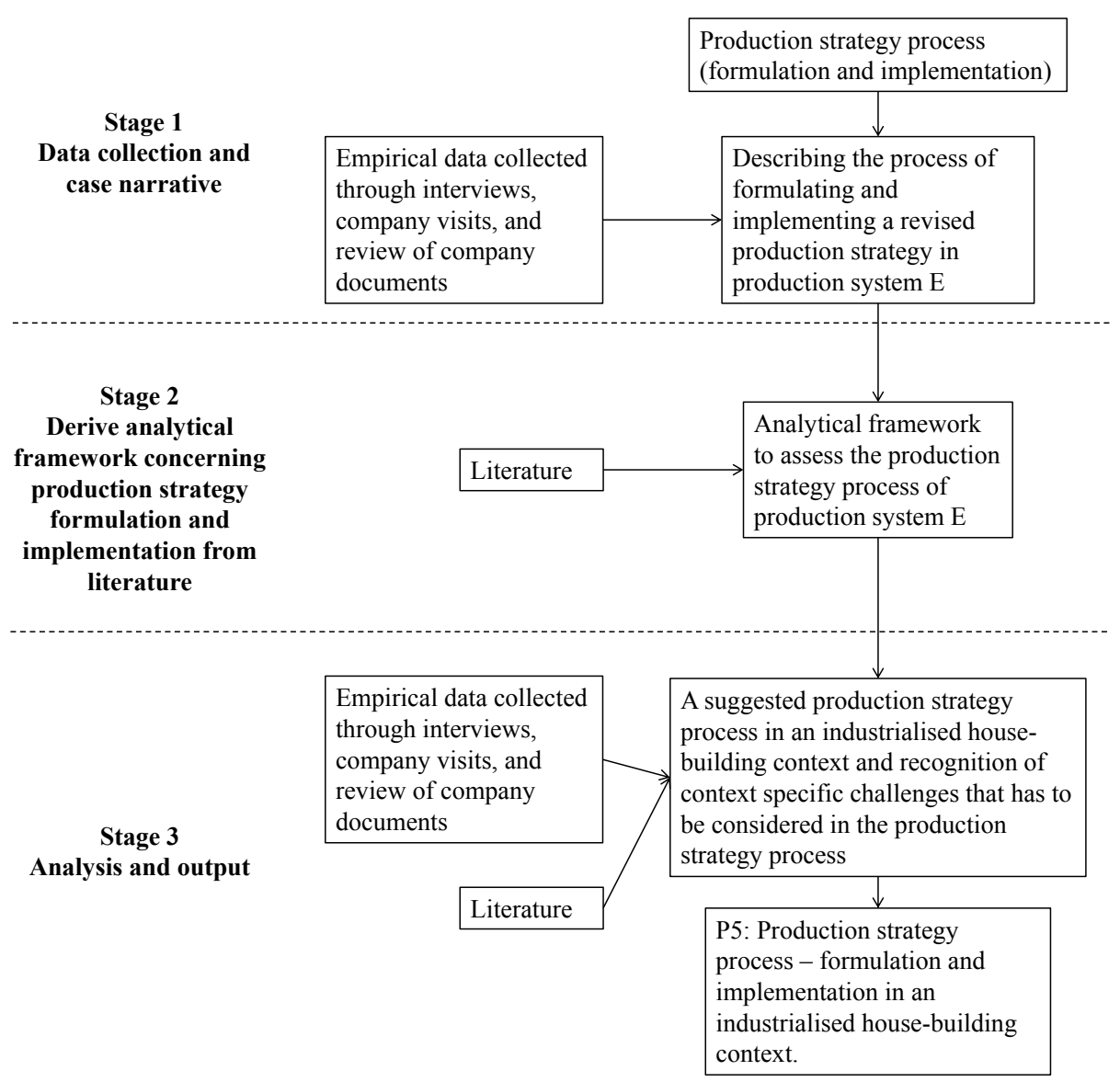

Figure 15 Research process Study 3

\subsubsection{Method Study 3}

This study is a single case study that can be seen as a revelatory case (Yin, 2013). To study the production strategy formulation and implementation process more or less when it happened was seen as a good opportunity to make a contribution to the production strategy process literature as this part of the production strategy literature has received less attention than the production strategy content literature (Dangayach and Deshmukh, 2001). The study is based on empirical data from an industrialised house-builder (Production system E). 
Data was collected through multiple sources, i.e. interviews, observations and review of company documents. Interviews were performed with persons with different functions within the organisation. Semi-structured interviews were performed with totally six key informants and their function, length of interview and main topics of each interview are summarised in Table 19.

Table 19 Summary of interviews performed in Study 3

\begin{tabular}{|c|c|c|}
\hline $\begin{array}{l}\text { Function of key } \\
\text { informants }\end{array}$ & $\begin{array}{l}\text { Perspective on the } \\
\text { production strategy process. }\end{array}$ & Information about the interview \\
\hline $\begin{array}{l}\text { VP Product } \\
\text { development, Industrial } \\
\text { Production \& Supply } \\
\text { Chain }\end{array}$ & $\begin{array}{l}\text { Background and company } \\
\text { information, formulation } \\
\text { process, implementation }\end{array}$ & $\begin{array}{l}\text { Interview performed in person } \\
\text { Recorded on tape } \\
\text { Duration } 3,5 \text { hours including } 2,5 \text { hours } \\
\text { recorded interview }\end{array}$ \\
\hline $\begin{array}{l}\text { Director of technical } \\
\text { development }\end{array}$ & $\begin{array}{l}\text { Formulation process, technical } \\
\text { development of the new } \\
\text { product and building system }\end{array}$ & $\begin{array}{l}\text { Interview performed in person } \\
\text { Recorded on tape } \\
\text { Duration } 2 \text { hours }\end{array}$ \\
\hline $\begin{array}{l}\text { Head of construction } \\
\text { management on-site }\end{array}$ & $\begin{array}{l}\text { Formulation and } \\
\text { implementation on-site }\end{array}$ & $\begin{array}{l}\text { Interview performed by phone } \\
\text { Recorded on tape } \\
\text { Duration } 1,5 \text { hours }\end{array}$ \\
\hline $\begin{array}{l}\text { Technical support in the } \\
\text { off-site facility }\end{array}$ & $\begin{array}{l}\text { Implementation process of site } \\
\text { and communication between } \\
\text { off-site production and on-site } \\
\text { assembly }\end{array}$ & $\begin{array}{l}\text { Interview performed in person } \\
\text { Recorded on tape } \\
\text { Duration } 2 \text { hours }\end{array}$ \\
\hline Project manager & $\begin{array}{l}\text { Implementation on-site and } \\
\text { project development }\end{array}$ & $\begin{array}{l}\text { Informal interview performed on } \\
\text { construction site during a site visit. } \\
\text { Duration } 3 \text { hours including } 1 \text { hour informal } \\
\text { talk about project development and } \\
\text { implementation on-site }\end{array}$ \\
\hline Site manager on-site & Implementation on-site & $\begin{array}{l}\text { Informal interview performed on } \\
\text { construction site during a site visit. } \\
\text { Duration } 3 \text { hours including } 1 \text { hour informal } \\
\text { talk about the production process before } \\
\text { and after change }\end{array}$ \\
\hline
\end{tabular}

In addition to the interviews, observations were made during visits both in the off-site facility and on a construction site where a house were assembled. The observations were made to get an understanding of the production process. This was helpful when conducting the interviews. The third source of information was review of company documents. Access to the company database was given and documents regarding the production strategy process could be accessed and used to cross-check data collected through the interview.

\subsection{Research quality}

Theory can be developed combining findings in previous literature, common sense and experience. Yet, it is the connection between this and empirical data that permits development of a testable, relevant and valid theory (Eisenhardt, 1989). This research is based on qualitative data collected from different production systems and analysed to draw conclusions. In this type of research it is particularly important to pay attention to reliability and validity (Karlsson, 2009). However to measure the quality of qualitative research using 
the criteria reliability and validity has been questioned (see e.g. Golafshani, 2003, Halldorsson and Aastrup, 2003, Stenbacka, 2001). The general critique is that the concepts of reliability and validity is drawn from a positivistic ontological standpoint (Halldorsson and Aastrup, 2003) that is more applicable on quantitative research (Golafshani, 2003). For a more qualitative/naturalistic research approach other criteria should be used to judge the research quality, such as credibility, neutrality or confirmability, consistency or dependability and applicability or transferability (Lincoln and Guba, 1985).

This research is mainly based on a deductive approach (Study 3 excluded) were empirical data is used for theory testing. This is more in line with a positivistic standpoint despite the fact that this is qualitative research. Hence, the quality of the research is discussed using the criteria reliability and validity.

Reliability is the extent to which a study can be repeated with the same results (Flynn et al., 1990, Stuart et al., 2002, Yin, 2013). Validity is usually divided into three different types, i.e. construct validity, internal validity, and external validity (Stuart et al., 2002, Voss et al., 2002, Yin, 2013). Construct validity is the extent to which we establish correct operational measure for the concepts being studied. Internal validity is the extent to which we can establish a causal relationship, whereby certain conditions are shown to lead to other conditions and finally, external validity is knowing whether a study's findings can be generalised beyond the immediate study (Voss et al., 2002).

To evaluate the quality of this research Yin's (2013) four "tests" to assess reliability and the three dimensions of validity is used. Table 20 describes means to ensure validity and reliability.

Table 20 Means to ensure validity and reliability (Yin, 2009 p. 41)

\begin{tabular}{|c|c|c|}
\hline Test & Case study tactic & $\begin{array}{l}\text { Phase of research in } \\
\text { which tactic occurs }\end{array}$ \\
\hline Construct validity & $\begin{array}{l}\text { - } \\
\text { - } \\
\text { - } \\
\text { - Have multiple sources of evidence } \\
\text { study report }\end{array}$ & $\begin{array}{l}\text { Data collection } \\
\text { Data collection } \\
\text { Composition }\end{array}$ \\
\hline Internal validity & $\begin{array}{ll}\text { - } & \text { Do pattern matching } \\
\text { - } & \text { Do explanation building } \\
\text { - } & \text { Address rival explanations } \\
\text { - } & \text { Use logic models }\end{array}$ & $\begin{array}{l}\text { Data analysis } \\
\text { Data analysis } \\
\text { Data analysis } \\
\text { Data analysis }\end{array}$ \\
\hline External validity & $\begin{array}{l}\text { - Use theory in single-case studies } \\
\text { - } \quad \text { Use replication logic in multiple-case studies }\end{array}$ & $\begin{array}{l}\text { Research design } \\
\text { Research design }\end{array}$ \\
\hline Reliability & $\begin{array}{ll}\text { - } & \text { Use case study protocol } \\
\text { - } & \text { Develop cases study database }\end{array}$ & $\begin{array}{l}\text { Data collection } \\
\text { Data collection }\end{array}$ \\
\hline
\end{tabular}

\subsubsection{Reliability}

"A non-reliable measure is like an elastic tape measure; the same thing can be measure a number of times, but it will yield different length each time" (Flynn et al., 1990, p. 265). A good reliability is also a prerequisite to establish validity. If a study can't be repeated and come to the same result, a high degree of validity is meaningless. A thing that should be 
considered related to the reliability of this research is that the data from the cases are collected and analysed by specific persons. To know if the results had been exactly the same if the study had been performed by another researcher is more or less impossible. The main findings however should be the same independent of who is doing the research.

To ensure reliability in this research:

- Structured and well prepared research protocols have been used when interviewing persons representing different functions in the organisation.

- The documentation from the interviews is stored digitally by the researcher so it can be reviewed and controlled.

- In the cases where the interviews have been recorded, the original recordings are also stored digitally by the researcher.

\subsubsection{Construct validity}

Construct validity is defined as having the right measures for a studied object (Yin, 2009). To ensure construct validity:

- For study 1 and 3 data has been collected from multiple sources, i.e. review of publicly available information, interviews, archival data, and observations. For Study 2 the main source for collecting empirical data was interviews, that data has not been triangulated using other sources which decreases the construct validity of Study 2.

- The iterative process in Study 1, going from findings from the literature review to empirical data back to theory for development and further refinement of the constructs should strengthen the construct validity of the research

- After the data collected through interviews had been compiled the draft notes sent to the respondents for validation.

\subsubsection{Internal validity}

Internal validity is the confidence that can be placed in the cause and effect relationship in a study (Yin, 2013), i.e. can there be an alternative cause, than the one presented, that explain the observations and results. Internal validity is mainly a concern for explanatory research (Yin, 2013). In this research Study 1 and Study 3 are explanatory hence the internal validity discussed for these studies. Study 2 is more of an exploratory nature, i.e. explore how the process choice affects information exchange in a house-building context, hence internal validity is not an issue in Study 2 .

To ensure internal validity:

- Alternative explanations have been considered and valued throughout the research process.

- In this research the empirical data was matched with predicted results in terms of conceptual models derived from literature. This is in line with the description of 
pattern matching given in Yin (2013) and also a way to strengthen the internal validity of this study.

- One thing that decreases the internal validity for Study 1 is that the case companies' ability to deliver manufacturing outputs has not been measured. This is due to limited access to the case companies. The effect is that no quantitative evaluation of how the position in the suggested classification matrix affects the ability of a production system to perform could be done.

\subsubsection{External validity}

External validity describes to what extent the findings in the study can be generalized beyond the immediate case (Yin, 2009).

To achieve external validity in this research:

- The approach for Study 1 and 2 is in line with theoretical replication where the results from the different production systems exposes differences between different production systems, but for predictable reasons.

- In Study 1 the sample of cases was deliberately chosen to represent different types of production systems for production of multifamily residences. This makes the findings generalizable in a house-building industry context. All the production systems that took part in the research considered the findings useful which, in some sense, strengthen the external validity. However, the sample of case companies is small and to be sure that the results can be used for all types of production systems, for production of multifamily residences, a larger sample of case companies is needed.

- In Study 2 the findings are based on empirical data from three different production systems representing the extreme cases in terms of the degree of off-site assembly (traditional production on-site and modular building) and also a production system representing a position in between the two extremes. Given this the external validity of this study is considered good but with the potential to be strengthen further by studying a larger sample of production systems and also alternative perspectives from, e.g. suppliers, subcontractors, clients etc.

The external validity is more problematic in Study 3 since it is a single case study. However, in an attempt to strengthen external validity of Study 3, and achieve analytical generalisation, the empirical data and findings are related to theory and reflected upon in a broader context than the immediate case. 



\section{Results}

The result of this research is the outcome the three studies presented in this thesis and also answers to the research questions presented in chapter 4 . In this chapter the results of this research are presented and the four research questions are answered.

\subsection{Classification of production systems in house-building}

The first research question considers categorisation of different production systems for production of multifamily-houses. Previous research (see e.g. Barlow and Ozaki, 2005, Doran and Giannakis, 2011, Gann, 1996, Segerstedt and Olofsson, 2010) that classify off-site production systems do not specifically address the importance of how orders are actually won in the market and that different market segments have different requirements that has to be linked to the design of the production system. In Paper 1 (Jonsson and Rudberg, 2014), production strategy literature was used as a base to develop a framework (Figure 16) to address this, linking market requirements, via the product offering, to the design of the production system. The classification matrix (left hand side of Figure 16) positions typical production systems based on their respective degree of product standardization and volumes relative the degree of off-site production. The list of drivers and barriers for industrialised house-building (Table 8), indicate that production systems for house-building deliver manufacturing outputs at different levels, hence the process choice will affect the production system's ability to perform in different areas of competition.

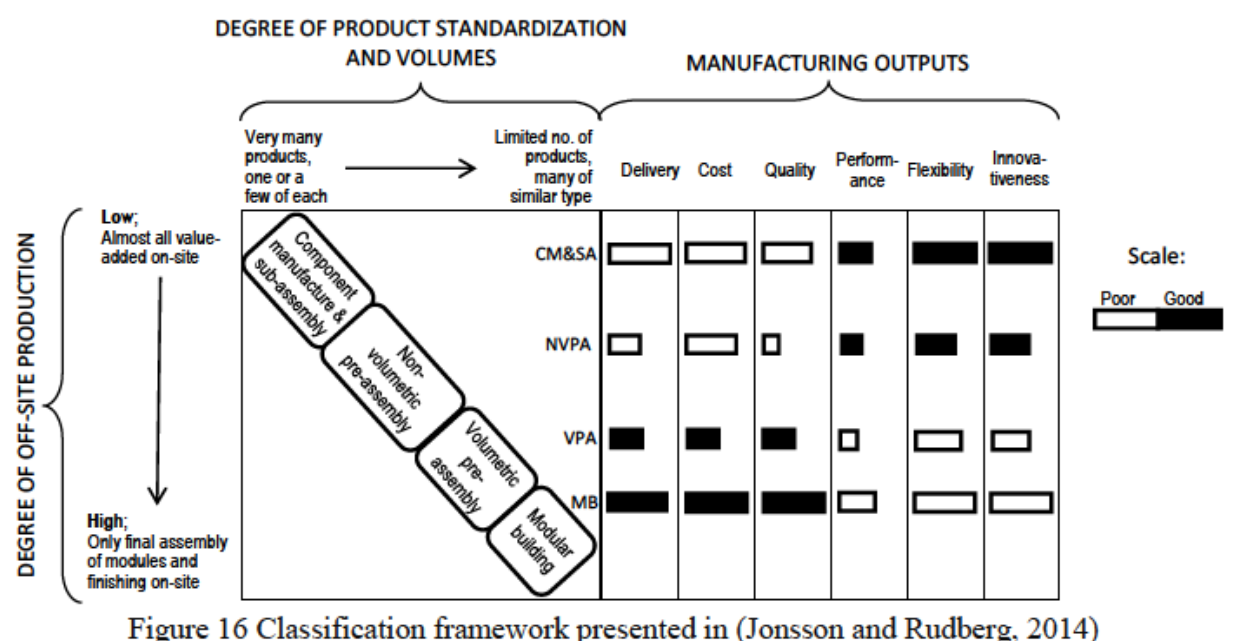

The applicability of the framework is exemplified through three case illustrations of off-site 
production systems, and it shows that the framework can be used to analyse the relative strengths and weaknesses of a production system. The framework can also be used as a guide when developing new, or adjusting existing, production systems for production of multifamily houses so that they will match market requirements and offer competitiveness.

The next step in developing the classification framework (Figure 16), was to test and possibly verify the usefulness of the matrix based on empirical data. For this purpose a set of case companies representing different types of production systems were identified, contacted and analysed. In this process a number of shortcomings of the classification matrix (left part of Figure 16) were identified. The main shortcomings related to the difficulties of classifying the production systems correctly. The two main problems with the matrix was the use of floating scales in the two dimensions (the degree of product standardisation and volumes and degree of off-site production respectively) and the way that Gibb (2001) defined the generic production systems. Thereby in Paper 2 (Jonsson and Rudberg, 2015) the research turned into an iterative, abductive, process going between the empirical data and a further theorethical development of the classification matrix (Figure 16), in order to improve it and make it more usefull both for academics and practitioners.

The major changes made to the classification matrix (left part of Figure 16) was:

- Introducing Lampel's and Mintzberg's (1996) five categories of customisation instead of the floating scale of degree of product standardisation and production volumes. The five categories are:

- Pure standardisation refers to the case in which the end product is the same and where the customer does not get involved before taking possession of the product.

- Segmented standardisation, where firms respond to the needs of different clusters of customers but the product for each cluster is standardised.

- Customised standardisation, where products are made to order from standardised components, this can also be called standardised customisation, modularisation or configuration.

- Tailored customisation requires a basic product that can be customised in the fabrication stage.

- In pure customisation the product is customised from scratch

This way of defining different degrees of product standardisation facilitates the classification by using fixed segments for classifying the production systems' product characteristics.

- Using Gibb's (2001) four generic production systems as means to classify the production systems' process characteristics. This introduced fixed categories in terms of the degree of off-site production.

- Two out of Gibb's (2001) four generic production systems were slightly adjusted to better reflect the companies producing whole buildings as the main contractor:

- Pre-fabrication \& Pre-assembly (PF\&PA) replaced Gibb's Volumetric Preassembly (VPA). PF\&PA is a situation not only including a high degree of prefabrication, but also some degree of pre-assembly off-site. 
- Gibb's Non Volumetric Pre-assembly (NVPA) was renamed to Pre-fabrication \& Sub-assembly (PF\&SA) to better follow the terminology of the matrix, however the description of this type production system correspond directly to NVPA.

- The fixed positions along the diagonal was removed to better reflect that all companies, deliberately or by accident, do not have a perfect match between the product and process characteristics, but can still perform well if the deviation is managed correctly.

The result of these changes is the classification matrix presented in Figure 17.

\section{DEGREE OF PRODUCT STANDARDISATION}

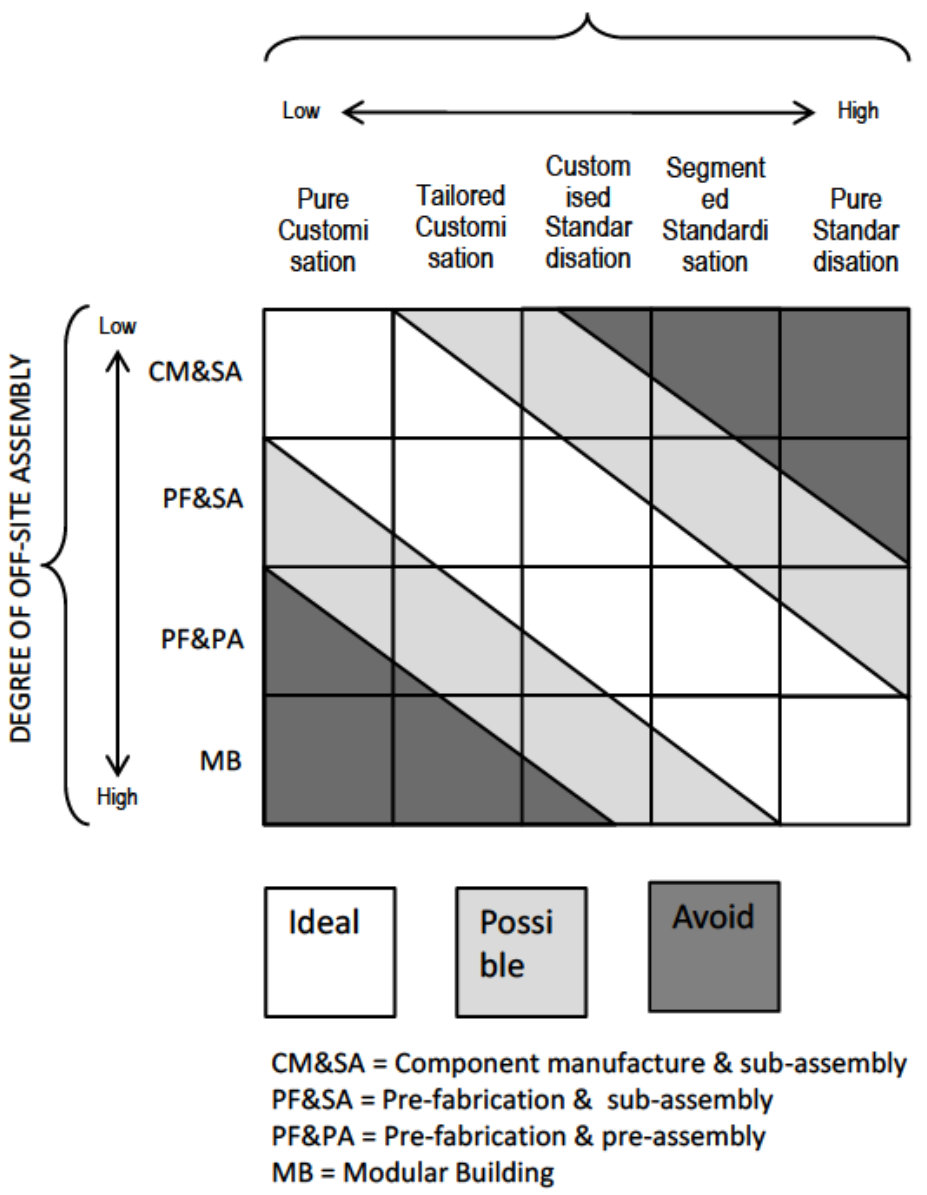

Figure 17 Revised classification matrix presented in Jonsson and Rudberg (2015)

The revised classification matrix (Figure 17) represent the answer to research question 1 . The classification matrix is inspired by the product-process matrix (Hayes and Wheelwright, 1979) and can, in a similar way, be used to match the characteristics of the product to the layout/design of the production process, in a house-building context. This is a first important step in addressing the link between process choice to market requirements that has not been explicitly addressed in previously literature categorising different types of production systems 
for house-building (see e.g. Barlow and Ozaki, 2005, Doran and Giannakis, 2011, Gann, 1996, Kadir et al., 2006) The result of the research suggests that a useful way to classify production systems for production of multifamily houses is along the dimensions; degree of product standardisation and the degree of off-site assembly.

\subsection{Performance measurement}

The first part of research question 2 consider which competitive priorities that are important to measure when evaluating different production system on a strategic level. In this first phase, the results from a literature review is used to define what to measure, i.e. which manufacturing outputs that have to be taken into consideration when evaluating a production system in a house-building context.

In Paper 1 a quite extensive list of drivers and barriers were found in the literature, (Jonsson and Rudberg, 2014), see Table 8. The list of drivers and barriers for off-site production is longer than the list of competitive priorities listed in Table 7. However, the drivers and barriers can be clustered and linked to the competitive priorities. The drivers and barriers are clustered under headlines based on traditional competitive priorities in Figure 18. Many of the drivers and barriers can be related to competitive priorities in more than one way. The relations presented in Figure 18 are considered direct relations. Other more indirect relations are not considered, for example, continuous improvement is related to quality but not to cost even though the work with continuous improvements probably has an indirect impact on cost. 


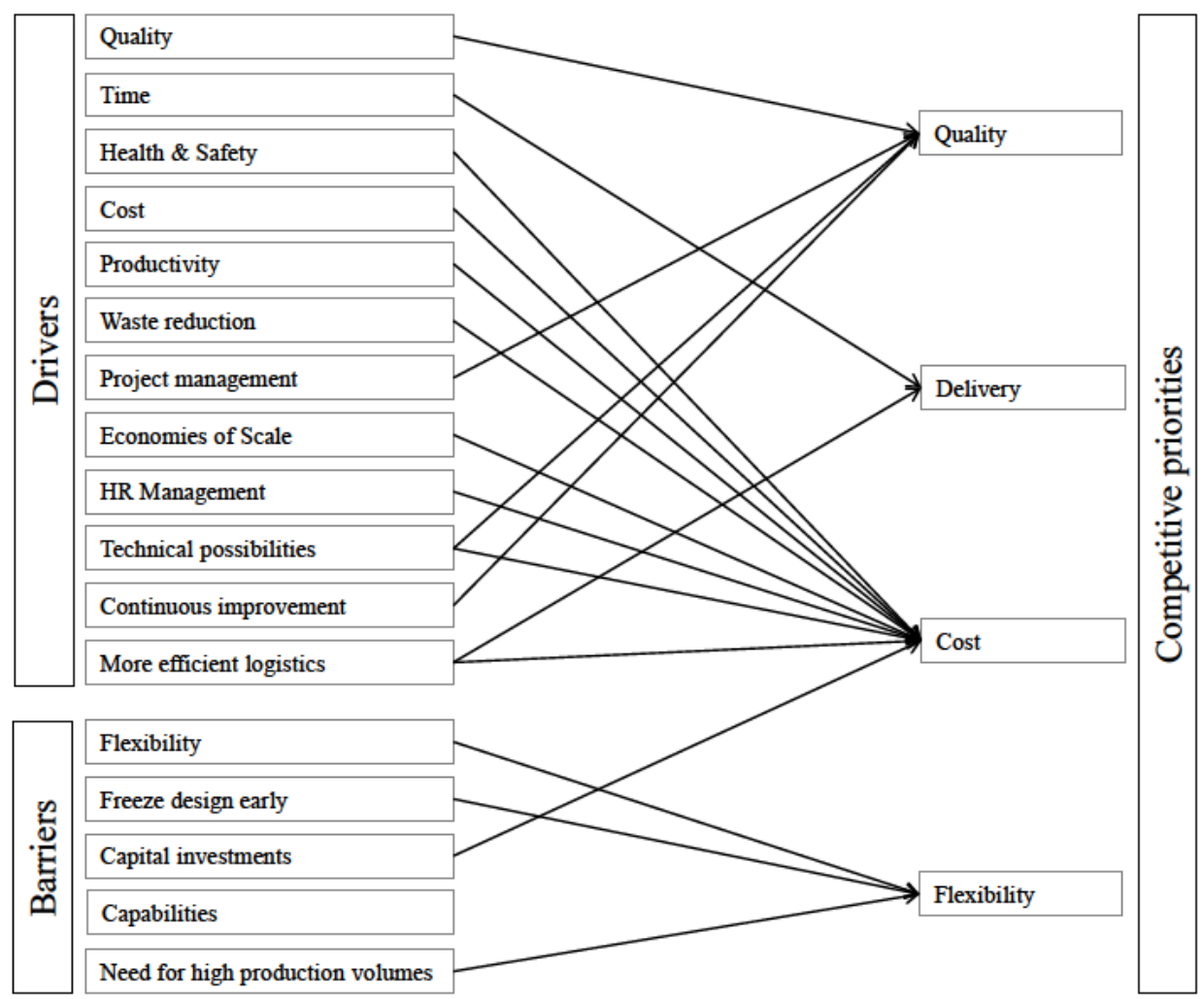

Figure 18 Drivers and barriers with industrialised house-building related to competitive priorities, see Paper 1 (Jonsson and Rudberg, 2014)

Comparing the drivers and barriers in with the typical competitive priorities in Table 7, it seems that off-site production offers competitiveness in terms of delivery, cost and quality whilst it reduces the flexibility of the production system. This indicates that a higher degree of off-site production is not always the right answer to improve operations in house-building, for instance exemplified by Kadir et al. (2006). Rather, a contingency approach must be followed when designing production systems, taking into account the ability of the chosen production system to perform, i.e. deliver manufacturing outputs, in different areas of competition.

Two of the competitive priorities in Table 7, performance and innovativeness, are included in Paper 1 (Jonsson and Rudberg, 2014). The reason for including them was that the framework developed in that publication to a large extent is based on Miltenburg's (2005) framework for production strategy in which both performance and innovativeness are included. However, there is no obvious link between the drivers and barriers for off-site production and performance and innovativeness respectively, therefore they are left out of the scope in Paper 2 and Paper 3 and focus is on the competitive priorities quality, delivery, cost and flexibility. These four "classical" competitive priorities are described as generic performance objectives that have meaning for all types of industries (Slack and Lewis, 2011), which also motivates the decision to narrow down the scope to only these four. 
Based on the review of drivers and barriers for off-site production and the link to competitive priorities, the first part of research question 2 can be answered. The following competitive priorities are considered relevant to measure when evaluating the ability of different production systems ability to perform, see Paper 3 (Jonsson and Rudberg, 2017):

- Quality

- Delivery

- Speed

- Dependability

- Cost

- Level

- Flexibility

- Dependability

- Volume

- Mix

The second part of research question 2, see Paper 3 (Jonsson and Rudberg, 2017), considers how performance, at a production strategy level, should be measured. In this research and a production strategy context a production strategy framework can be viewed upon as a system to manage performance and in such systems KPIs are argued to be useful to measure performance. Both Table 12 and Table 13 indicate that KPIs for measurement of the competitive priorities quality, delivery (speed and dependability) and cost (level and dependability) are defined for the house-building industry. What becomes apparent is that there is a lack of KPIs defined for measuring flexibility adapted to a house-building industry context.

Flexibility is an important aspect for all manufacturing companies. To be able to be competitive a company must be able to adapt to changing environmental influences. However, flexibility is a concept that is complex, multidimensional, and hard to capture and over 50 different terms of various flexibility can be found in manufacturing literature (Sethi and Sethi, 1990). To find KPIs for flexibility, traditional production strategy literature has been reviewed, see Paper 3 (Jonsson and Rudberg, 2017).

The result of this study is KPIs that can be used to measure performance at a production strategy level in a house-building context. KPIs are presented to measure quality, cost, delivery and flexibility. The suggested KPIs are validated using empirical data collected through interviews conducted with production systems A-E. The respondents gave their opinion on the suggested metrics and also accounted for how they work with performance measurement within each production system. The result of this deductive approach is a performance measurement system that is grounded in both theory and practice. The defined KPIs are presented in Paper 3, (Jonsson and Rudberg, 2017), see Table 21. 
Table $21 \mathrm{KPIs}$ for measuring production system performance in the house-building industry, see Paper 3 (Jonsson and Rudberg, 2017)

\begin{tabular}{|c|c|}
\hline $\begin{array}{l}\text { Competitive } \\
\text { priority }\end{array}$ & KPI \\
\hline Quality & $\begin{array}{l}\text { Quality for the } i \text { : th project }\left(Q_{i}^{p}\right)= \\
\qquad=\frac{\text { Cost for rectifying defects in project } i}{\text { Total production cost for project } i} \times 100 ; i=1,2, \ldots, n \\
\quad \text { Quality concept }\left(Q^{C}\right)=\frac{\sum_{i=n-N+1}^{n} Q_{i}^{p}}{N} \\
i=\text { Project index (running numbers) } \\
N=\text { Number of projects included in the moving average calculation }\end{array}$ \\
\hline $\begin{array}{l}\text { Delivery } \\
\text { speed }\end{array}$ & $\begin{array}{l}\text { Delivery speed for the } i \text { : th project }\left(D S_{i}^{p}\right)= \\
\qquad=\frac{\text { Total production time for project } i}{\text { Total gross floor area for project } i} ; i=1,2, \ldots, n \\
\text { Delivery speed concept }\left(D S^{C}\right)=\frac{\sum_{i=n-N+1}^{n} D S_{i}^{p}}{N} \\
\quad \begin{array}{l}\text { i= Project index (running numbers) } \\
N=\text { Number of projects included in the moving average calculation }\end{array}\end{array}$ \\
\hline $\begin{array}{l}\text { Delivery } \\
\text { dependability }\end{array}$ & 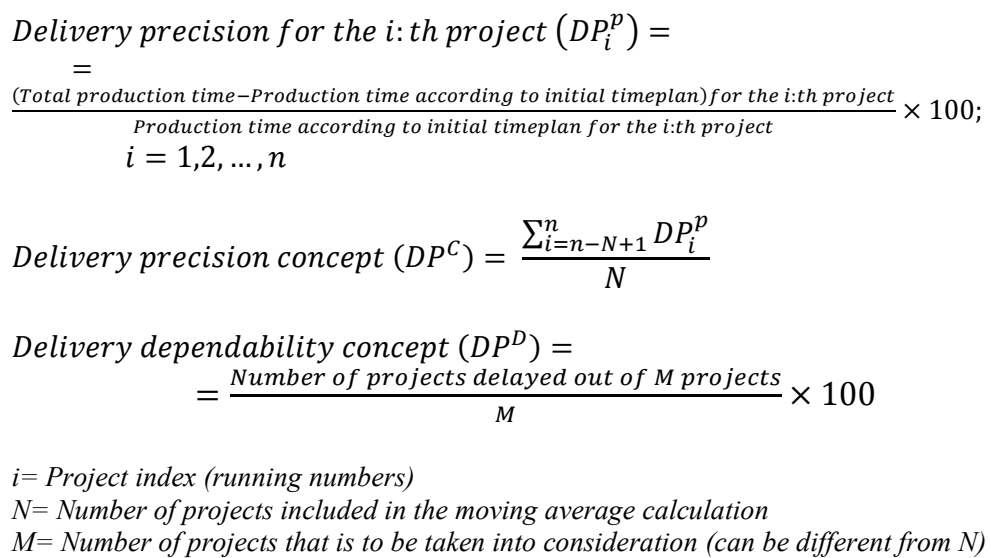 \\
\hline
\end{tabular}




\begin{tabular}{|c|c|}
\hline $\begin{array}{l}\text { Competitive } \\
\text { priority }\end{array}$ & KPI \\
\hline Cost level & $\begin{array}{l}\text { Cost level for the } i \text { : th project }\left(C L_{i}^{p}\right) \\
\qquad=\frac{\text { Total production cost for project } i}{\text { Total gross floor area for project } i} \\
\qquad i=1,2, \ldots, n\end{array}$ \\
\hline $\begin{array}{l}\text { Cost } \\
\text { dependability }\end{array}$ & 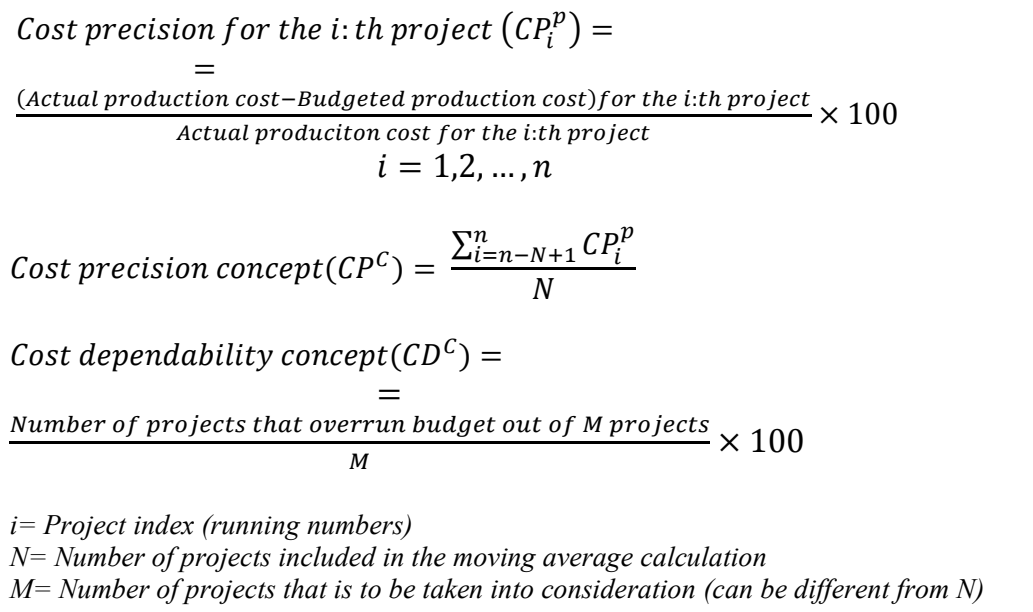 \\
\hline $\begin{array}{l}\text { Volume } \\
\text { flexibility }\end{array}$ & $\begin{array}{l}\text { Volume flexibility concept }\left(V F^{C}\right) \\
\quad=\text { Maximum capacity - Volume at Breakeven Point }\end{array}$ \\
\hline Mix flexibility & $\begin{array}{l}\text { Mix flexibility concept }\left(M F^{C}\right)=\frac{\sum_{i=n-N+1}^{n} \Delta C M_{i}^{p}}{N} \\
i=\text { Project index (running numbers) } \\
\Delta C M_{i}^{p}=\text { the relative deviation from the contributing margin of the optimal project for } \\
\text { project } i \\
N=\text { Number of projects included in the moving average calculation }\end{array}$ \\
\hline
\end{tabular}

The KPIs presented in Table 21 represent the answer to the second part of research question two. The KPIs can be used to measure the ability of different production systems to deliver manufacturing outputs in different areas of competition using quantitative data instead of qualitative estimations that have been used in previous literature (see e.g. Arif and Egbu, 2010, Blismas et al., 2006, Gibb, 2001, Halman et al., 2008). 


\subsection{Information exchange in house-building}

Research question 3 concerns how the process choice influences information exchange in a house-building context. Four challenging characteristics related to house-building and the implication for information exchange were identified using literature, see Table 5. In Paper 4 (Jonsson and Gosling, 2017) empirical data from production systems B, D and $\mathrm{H}$ was used to see to what extent the challenges could be observed for the different production systems. To be able to compare different types of production systems they were deliberately chosen to have different positions in the classification matrix (Figure 17), hence representing different degrees of off-site assembly and product standardisation, see Figure 19.

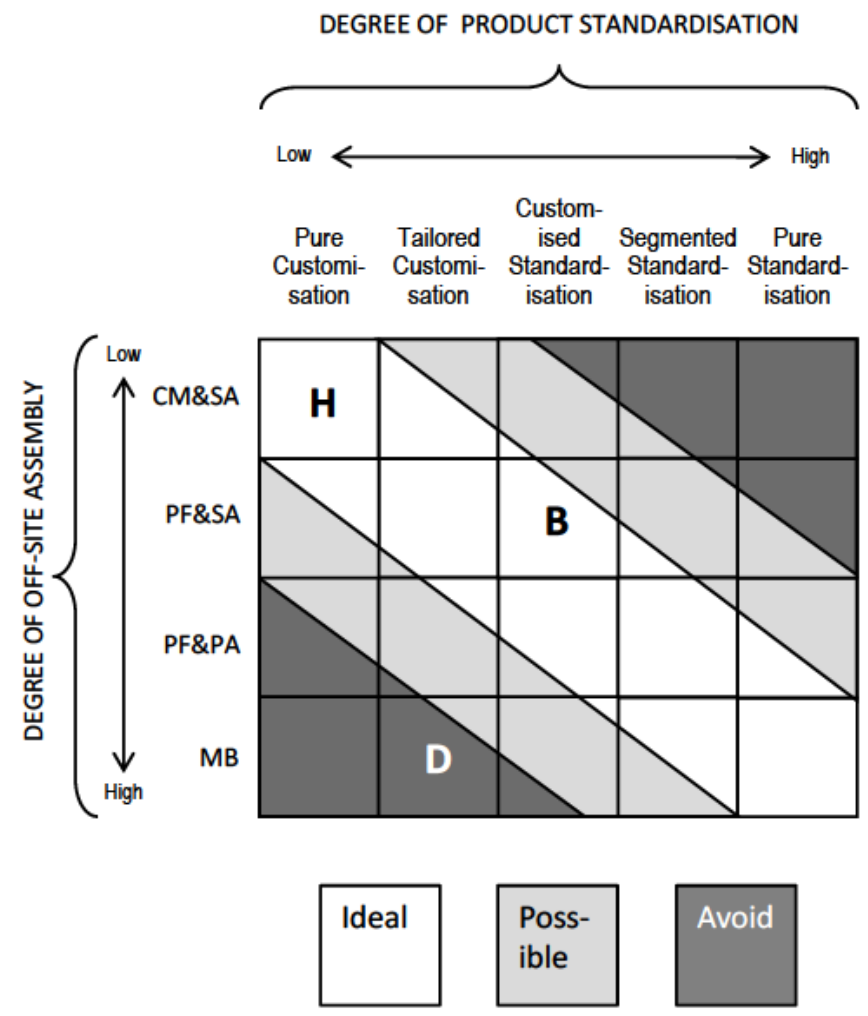

Figure 19 Classification of production systems B, D, and $\mathrm{H}$

The production systems position in the classification matrix was then related to the challenges to see what impact process choice had on the information exchange challenges. The result can be seen in Table 22 . 
Table 22 Comparison of the production systems regarding information exchange challenges

\begin{tabular}{|l|c|c|c|}
\hline Challenge & $\begin{array}{l}\text { Production } \\
\text { system B }\end{array}$ & $\begin{array}{l}\text { Production } \\
\text { system D }\end{array}$ & $\begin{array}{l}\text { Production } \\
\text { system H }\end{array}$ \\
\hline $\begin{array}{l}\text { 1. Temporary supply chains, due to project } \\
\text { environment }\end{array}$ & + & + & - \\
\hline $\begin{array}{l}\text { 2. Long and fragmented supply chains, as a result } \\
\text { of outsourcing many specialist trades }\end{array}$ & + & + & - \\
\hline $\begin{array}{l}\text { 3. Projects are engineered-to-order, since each } \\
\text { project has a degree of uniqueness }\end{array}$ & + & - & - \\
\hline $\begin{array}{l}\text { 4. Reluctance to embrace new ICT solutions, } \\
\text { caused by a complex range of issues. }\end{array}$ & + & + & - \\
\hline
\end{tabular}

- Observed to a large extent

+ Observed to a lesser extent

Production system B, using a higher degree of off-site assembly and product standardisation than Production system H (Figure 19), has reduced many of the typical challenges. Some of the good observed practices are that they work with a relatively small supply base and they have long term agreements with suppliers and sub-contractors. They also use ICT-based approach to information exchange, for example, they use an ERP-system for information exchange and BIM to facilitate the design of the product. The modular approach using standardised components with integrated interfaces in combination with BIM reduces the uniqueness of the projects, hence reduces the complexity that comes with a high degree of product customisation.

Production system D, using a higher degree of off-site assembly than both Production system $\mathrm{H}$ and Production system B, and still a relatively high degree of customisation (higher than Production system B but lower than Production system H), has also been able to reduce some of the traditional challenges. They use a relatively small number of suppliers and subcontractors. The biggest challenge for them is exchanging information regarding the design of the product. However, they are well aware of this and have, through standardised processes and lean thinking in all steps of the process, been able to handle this. They use different types of ICT-systems than Production system B, such as project portals where all information concerning the specific projects are gathered, to support their process based approach to information exchange.

Production system H, positioned in the top left corner of the classification matrix (Figure 19), displays all the traditional challenges, to a large extent. The richness of information that comes with a high degree of customisation and production on-site was handled in temporary and fragmented supply chains. There was also an absence of ICT-solutions that could help the company to handle the complexity of the supply chain and information exchange. They use a traditional approach to information exchange in the projects such as different types of project meetings.

The findings of this study (Paper 4), and also the answer to research question 3, are presented in the form of two propositions.

Firstly, production systems using some degree of off-site assembly have less complex supply chains with fewer suppliers and sub-contractors, as well as more stable supply chains which facilitates information exchange. 
The off-site facility can use the same suppliers from project to project and this facilitates information exchange, as exemplified by Production system B and D. This is more complex for the more traditional approach, exemplified by Production system $\mathrm{H}$, since the supply chain usually is temporary with new actors for each project. Even though the use of off-site production can facilitate the long term relations with only a few selected suppliers it is advocated that also house-builders using on-site production could benefit from a less fragmented supply chain using only a few trusted suppliers. However, this is a bigger challenge in that type of environment where the project organisations are more unique from project to project and due to the high degree of product customisation that typically is provided by that type of production system. This can also be an explanation to why Production system $\mathrm{H}$ has a more traditional approach (common in the house-building industry) to information exchange.

Secondly, production systems using some degree of off-site assembly and a high degree of product standardisation use ICT-solutions, e.g. ERP-systems, BIM, project portals, etc., to a larger extent than production systems using more traditional production methods on-site providing a high degree of product customisation.

A production system with a higher degree of off-site assembly typically uses a higher degree of product standardisation. This is true for Production system B that has managed to combine customised standardisation with the use of both an ERP-system and BIM. The combination of off-site assembly and a relatively high degree of product standardisation seem to facilitate the use of an ICT-based approach to information exchange within the organisation and in the supply chain. Production system D has a higher degree of off-site assembly than Production system B but also a higher degree of product customisation. They use a more process based approach to information exchange and use other types of ICT-solutions, such as project portals, to support the standardised processes for information exchange. This indicates that the increased degree of customisation makes it harder for them to use more sophisticated ICTsolutions such as ERP-systems and BIM. In productions system $\mathrm{H}$, providing pure customisation, there is a lack of ICT-solutions. The empirical data indicates that the degree of product standardisation affects what type of ICT-solution that is appropriate for different types of production systems.

The study gives a contextual interpretation of information exchange across different types production systems for house-building and shows that the process choice affects information exchange as described by the propositions. Previous research on information exchange in house-building typically consider traditional production methods on the construction site (see e.g. Dainty et al., 2006, Senaratne and Ruwanpura, 2016) or, in a few studies, industrialised house-building (see e.g. Bergström and Stehn, 2005, Persson et al., 2009). The contribution in this study lies in the comparison between different types of production systems. However, the sample of production systems is small and further research is needed to validate the findings. 


\subsection{Formulation and implementation of production strategy in industrialised house-building}

Research question 4 concerns the production strategy process. In Paper 5 (Jonsson and Fredriksson, 2017), the formulation and implementation of a new production strategy for an industrialised house-builder is studied.

The main findings of this study is a suggested production strategy process in an industrialised house-building context, see Figure 20.

\section{Production strategy process}
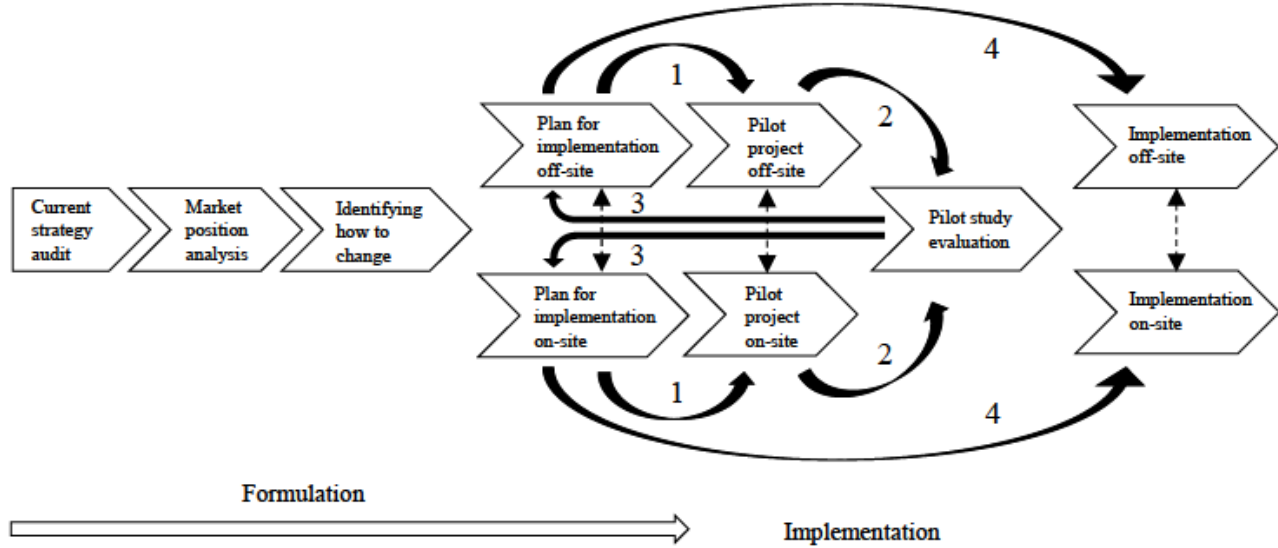

Figure 20 Suggested production strategy process in an industrialised house-building context, see Paper 5 (Jonsson and Fredriksson, 2017)

The studied formulation process used by the industrialised house-builder followed the four steps in in the suggested production strategy process (Figure 20) to a large extent and is considered a good example of how the formulation process can be structured and performed in an industrialised house-building context. Other companies can learn from this if they face a change in production strategy.

Along with analysing how the formulation process was performed, a number of evaluation criteria also derived from literature, was used to evaluate other important factors of the formulation process.

The industrialised house-builder used objectives to give the formulation process direction without limiting the creativity of the working group assigned to develop the new production strategy. The working group included persons from different parts of the organisation. This indicates good participation in the production strategy process, which facilitated visibility and communication of the new production strategy throughout the different functions in the organisation. The initiative to make the change came from top management and the way they 
used the objectives as a steering mechanism, and the use of knowledge from different parts of the organisation indicates good leadership in the formulation process.

The implementation process is a less structured and more behaviourally oriented process than the formulation process. When analysing the studied implementation process and comparing it to the suggested production strategy process in Figure 20, a number of shortcomings were identified. The industrialised house-builder followed the suggested implementation process to some extent but missed out on some important activities in the implementation process.

The implementation process studied in this research started with a pilot project. However the pilot project was not evaluated and documented properly and the potential learnings from the pilot project was not transferred to future projects, hence arrow 3, in Figure 20, was missing in the studied implementation process. This highlights the importance of managing the pilot project both in the production phase but also in the evaluation phase.

For the full implementation they decided to use a phased in approach. The new production strategy was gradually implemented over a time period of approximately two years. This way of implementing the change gave time for reflection between the projects and also reduce the negative economic consequences that comes with implementing a new product and setting up a new production system. The potential downside of implementing the change gradually is that the production system has to handle two types of products over a limited time period. This may affect the learning curve negatively and potentially cause quality issues, due to mixing two different building systems. These aspects have to be considered before deciding what approach to use in the implementation phase. The gradual implementation in the studied production strategy process was considered a good approach since the change was a proactive move to increase market share and stay competitive and not triggered by crisis and a struggle to survive in such scenario a Big-bang approach might have been more suitable.

The production process of an industrialised house-builder is divided into two separate production processes, pre-fabrication off-site and construction work on-site. When changing the production strategy, in that type of production system, it is important to recognise that the change affect the different production processes differently. In the studied case, the goal to extend the market share resulted in an increased degree of customisation. This increase in product flexibility was handled to a large extent in the on-site production process (see, Figure 21 ), as the product standardisation moved from the house to the module in the product hierarchy. The result of this, perhaps a bit simplified, was that the production process off-site could continue to produce basically six standard modules whilst the on-site production process went from producing one standardised house to producing unique houses for each project in terms of number of floors and size. Given this, the implementation process should have focused on preparing the implementation on-site to a larger extent than what they did. Instead focus was mainly on the implementation process in the off-site facility. This imbalance between impact and preparation for the implementation is visualised in Figure 21. 


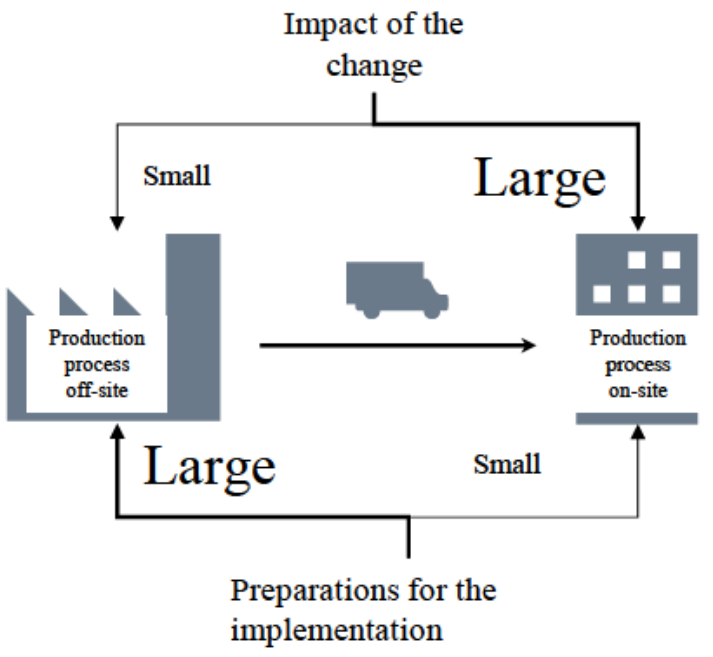

Figure 21 Imbalance between change impact and preparation for implementation for the studied case

The implementation off-site is of course important but it should be a better balance between the off-site and on-site process in implementing a revised production strategy.

The decision to make change was a pro-active initiative to stay competitive and increase market share. The change met resistance and raised concern mainly amongst personnel in the off-site facility. To get the staff in lower levels of the organisation to accept and embrace the change was one of the biggest challenges during the whole change process. This could perhaps have been mitigated if the expected impact of the change, especially in the off-site facility, had been analysed and communicated better throughout the organisation.

Change is challenging (Szulanski, 2000) and even more so in a house-building context (Titus and Bröchner, 2005). The suggested process model for the production strategy process in an industrialised house-building context (Figure 20) can help companies to formulate and implement a change in production strategy in a structured way. The suggested process models and identifying context specific challenges for industrialised house-builders in the production strategy process represent the answer to research question 4 and contributes to the production strategy process literature. 


\section{Discussion and further research}

In this chapter the practical implications of the research is discussed, by giving examples based on the empirical data collected in the research process, to increase understanding of how this research can help companies in formulating and implementing a sound production strategy. With a sound production strategy, house building companies can meet the challenges of today and tomorrow effectively. In this chapter reflections on the research process is also accounted for and these reflections leads to suggestions for further research.

\subsection{Practical implications}

Production strategy research is an example of an applied science. In applied science the theoretical contribution should be accompanied by practical contributions. The practical implications of this research are presented using a number of examples related to the three studies in the thesis.

\subsubsection{Evaluating two different production systems}

In this example two competing production systems are compared using the classification matrix (Figure 17). Firstly, the characteristics of the two production systems are described to be able to position them in the classification matrix.

\section{Production system A}

The production system only delivers one type of product, tower blocks with four to eight floors. Each floor consists of a combination of standard apartments with one, two, three or four rooms. Offering the customers only one house type gives a relatively high production volume of similar products, and it is categorised as pure standardisation. The whole building is produced on-site, including components that normally are prefabricated, such as balconies, joists, and slabs. This concept is thereby classified as CM\&SA.

\section{Production system E}

This production system only offers the customers slab blocks with two floors. The slab blocks can be built either as I-, L- or U-shaped houses. Offering the customers only one type of house (slab blocks with two floors) gives a high production volume of similar products, also categorised as pure standardisation. Modules are produced off-site to a high level of completion. The interior of the modules are complete with floor, wallpaper, wardrobes and kitchen (appliances excluded due to risk of theft). The only activity performed on-site is the assembly. This concept is classified as MB. 
Based on the case descriptions the production systems have been positioned in the classification matrix, see left part of Figure 22.

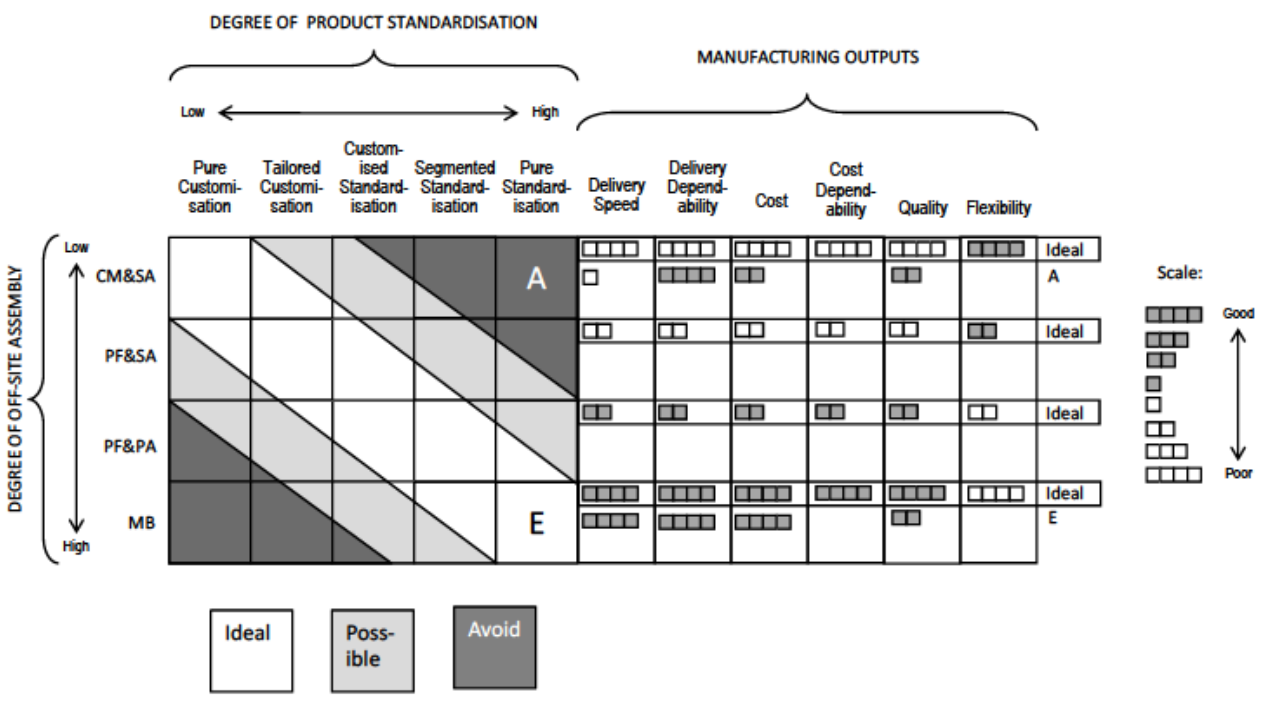

Figure 22 Comparing two different production systems in the production strategy framework

The position of the two production systems reveals that Production system E seems to have a match between the degree of production standardisation and the degree of off-site assembly, whilst Production system A is off the diagonal since they use a production system typically used to produce customised products to produce a standardised product. The interesting question is how this affects the different production systems' ability to deliver manufacturing outputs. Data were collected, both quantitative and qualitative, with the purpose of evaluating the production systems' ability to perform. Not all of the manufacturing outputs in the framework were measured but the data could be used to evaluate some of them. The result of that analysis is presented in the right hand part of Figure 22, by estimating the ability of the production systems to perform.

In Figure 22 it is clear that Production system A and Production system E, both offer a standardised house but use different strategies when it comes to the degree of off-site assembly. Production system E performs better in both production time and production cost. Since both concepts deliberately have chosen to produce a standardised product, a qualified guess would be that the order winning manufacturing output for both cases are either cost or delivery, with quality as a qualifying output. If that is the case, Production system A is outperformed by Production system E if the customer can accept the product that Production system E delivers. By positioning themselves off the diagonal in the classification matrix Production system A face a risk of being outperformed by other concepts positioned better in the classification matrix on all aspects of competition.

The classification matrix (Figure 17) is useful when evaluating the process choice and comparing different types of production systems as described above. What would make it even 
more useful is if the ability to deliver manufacturing outputs could be measured for different types of production systems.

\subsubsection{Performance measurement}

The KPIs developed in Study 1 (Table 21) can be used to monitor a production systems ability to perform over time, evaluate how redesigning the production system affects the production system's actual ability to perform, using quantitative data collected in the projects. By measuring performance before and after the change a comparison can be made to see if the change had desired effect on performance.

Another scenario where the KPIs can be useful is when a house-building company has developed different production systems targeting different markets. Production systems A, C, and $\mathrm{F}$ are an example of this. The three different production systems are positioned differently in the classification matrix, see Figure 23, and should potentially be competitive in different areas of competition. The KPIs can be used to measure the production systems relative ability to perform and gain knowledge that can help the house-building company to take the right strategic decisions concerning what production system to use for which project.

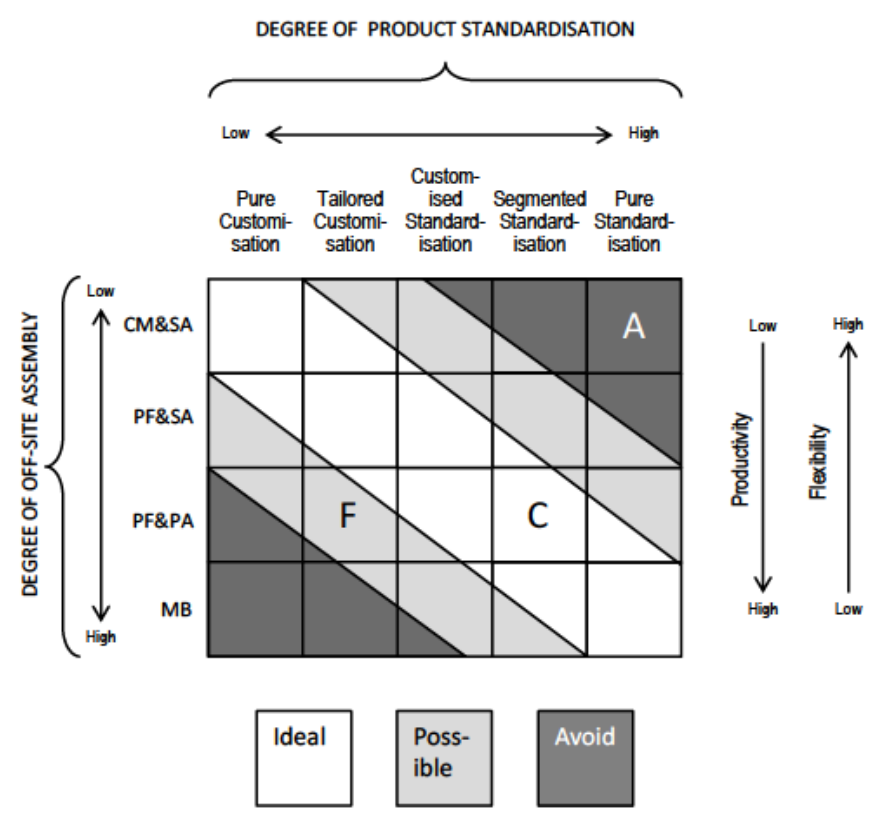

Figure 23 Position of three different production systems managed by the same construction company

\subsubsection{Production systems off the diagonal}

As stated in Figure 17 positions to far from the diagonal should typically be avoided. However, two of the production systems (Table 14) are positioned quite far of the diagonal Figure 24. 


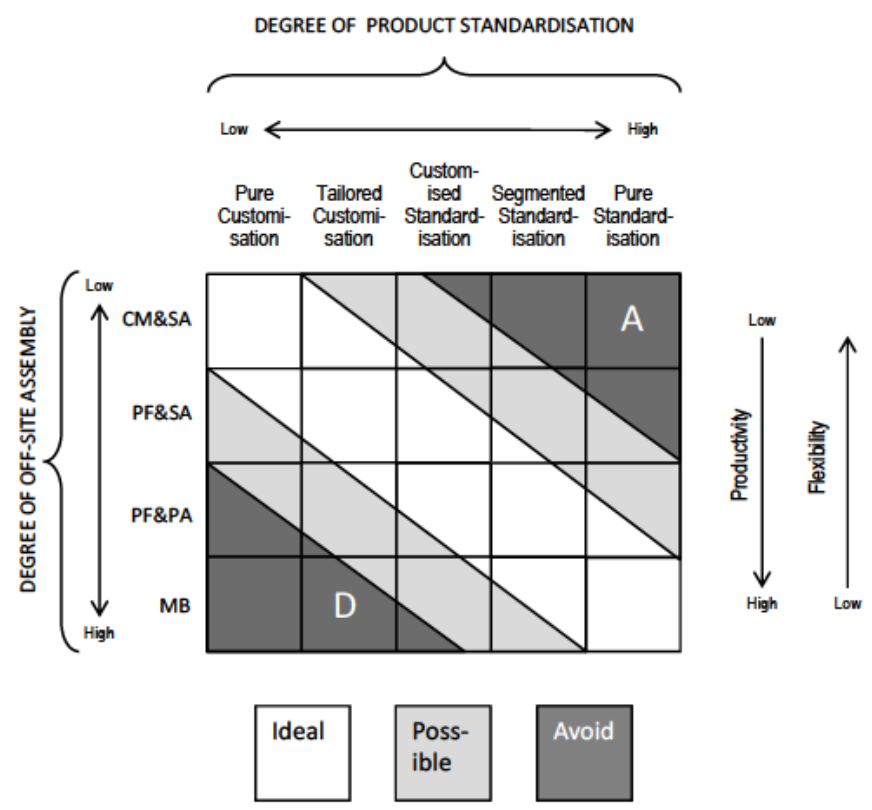

Figure 24 Positions of the diagonal that typically should be avoided

Production system A is positioned in the top right corner of the matrix. The reason for avoiding a position above the diagonal is that in that scenario a production system, designed to be flexible, is used to produce standardised products, hence the strengths of that type of production systems is not utilised. A decision to standardise the product is often based on a desire to be efficient, e.g. reduce production cost and lead times (Lampel and Mintzberg, 1996). By standardising the product, Production system A probably have managed to reduce production cost and delivery times compared to a production system positioned in the top left corner of the matrix, but at the expense of customisation. However, a production system with a better match between product and process characteristics, positioned in the bottom right corner of the matrix, is likely to outperform Production system A in terms of cost and time while offering the same degree of standardisation. As indicated by the arrows on the right side of the matrix a production system positioned at the top of the matrix is related to relatively low productivity. If that is combined with a high degree of product standardisation you end up with a production system that deliver poor performance both in terms of productivity and customisation, (a typical no-win situation), compared to production systems positioned better in the matrix.

Production system D is positioned below the diagonal. A position below the diagonal should be avoided for other reasons than a position above. To offer a high degree of customisation using a production system with a high degree of off-site assembly, without losing productivity, puts high demand on managing the production system. One risk is that the production volumes do not reach the levels needed to cover the large capital investments that come with production in an off-site facility. However, at the same time as a position below the diagonal of the matrix is related to high risk, it also comes with a high reward if successful. 
As opposed to a position above the diagonal, representing a no-win situation, a position under the diagonal combining productivity with flexibility in some sense represent a win-win situation, if the challenges and risks, that comes with a position under the diagonal, can be handled. Production system D (Table 14) is an example of a production system that, through standardised processes, based on lean thinking in all parts of the process and organisation, has managed to successfully combine a high degree of off-site assembly with a relatively high degree of customisation. They produce a relatively wide range of houses, designed after customer demands, using an efficient production system, producing modules in an off-site facility. This can be compared to Just-In-Time (JIT) production systems and Flexible Manufacturing Systems (FMS) where they have been able to combine a high degree of product variety produced in relatively low volumes with a line flow layout. This is done by dedication to continuous improvements, for example reducing set up time, and visualising waste and remove it (JIT) and by using flexible computer controlled machines and an automatic material handling systems (FMS).

\subsubsection{Information exchange in a house-building context}

In Study 2 the classification matrix (Figure 17) is used to categorise different production systems and then study how the process choice affects information exchange in a housebuilding context. The result of the study indicate differences in approach to information exchange between the three production systems B, D and $\mathrm{H}$ (Figure 25).

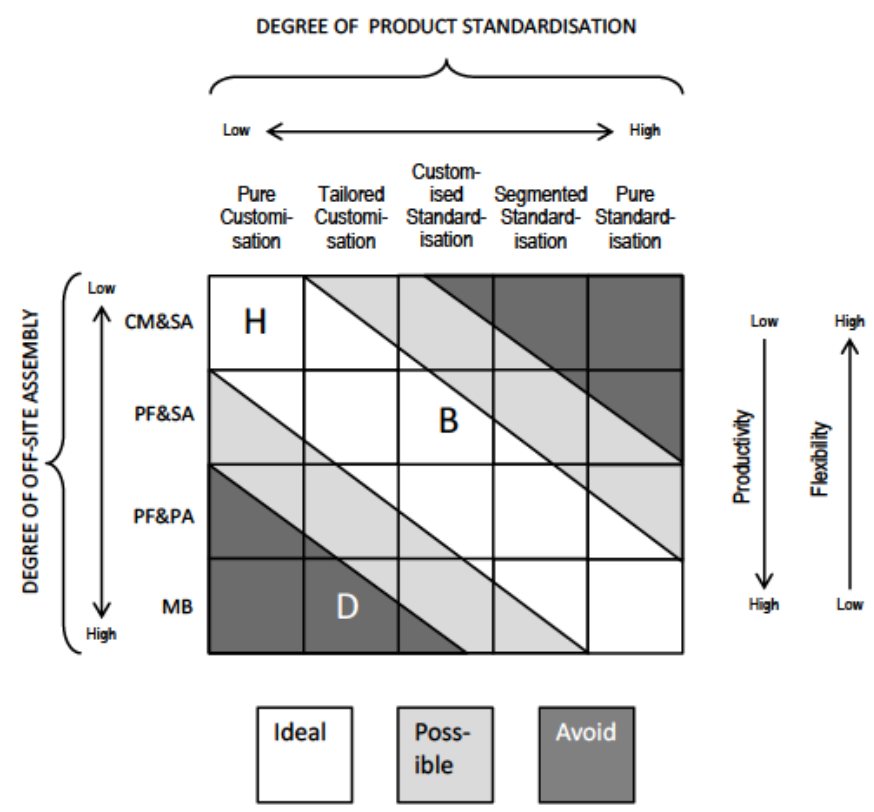

Figure 25 Position of the production systems used to study how the process choice affects information exchange in a house-building context.

The differences in approach to information exchange can be related to differences in supply chain structure and the complexity of design related information that has to be handled in the production system. 
This is an example of how the classification matrix can be used to research different dimensions of production strategy and compare different types of production systems, hence a practical implication, of this research, for other researchers. This way of using the classification matrix can be used to research other topics in a house-building context as long as a comparison is to be made between, e.g. different types of production systems, or before and after scenarios. Examples of other topics that can be investigated using the same approach are other decision categories such as vertical integration, corporate culture, organisation structure, etc. To have a structured way of categorising different types of production systems facilitates this type of research.

\subsubsection{Redesigning a production system}

In this example Production system E is used to describe a before and after scenario (see Table 14). The management of the firm decided to investigate the possibility to offer the customers residences with 2-4 floors, instead of only 2 floors, and they also wanted to offer the customers the possibility to change the design of the house to a larger extent than in the current system.

In this scenario the classification matrix (Figure 17) can be used to analyse what effects a suggested market strategy change have on the production function. Before the change Production system E used a production system with a high degree of off-site production (Modular Building) to produce a standardised product, hence was positioned on the diagonal (lower right corner) of the classification matrix (see Figure 26). The suggested changes of the product characteristics meant that they decreased the degree of standardisation and now offer a more customised product. This means that they moved to the left in the classification matrix. The suggested changes comprises both an increase in the number of floors and offering a higher degree of customisation. If the product characteristics are changed the new position is the classification matrix would be somewhere between segmented standardisation and customised standardisation. 


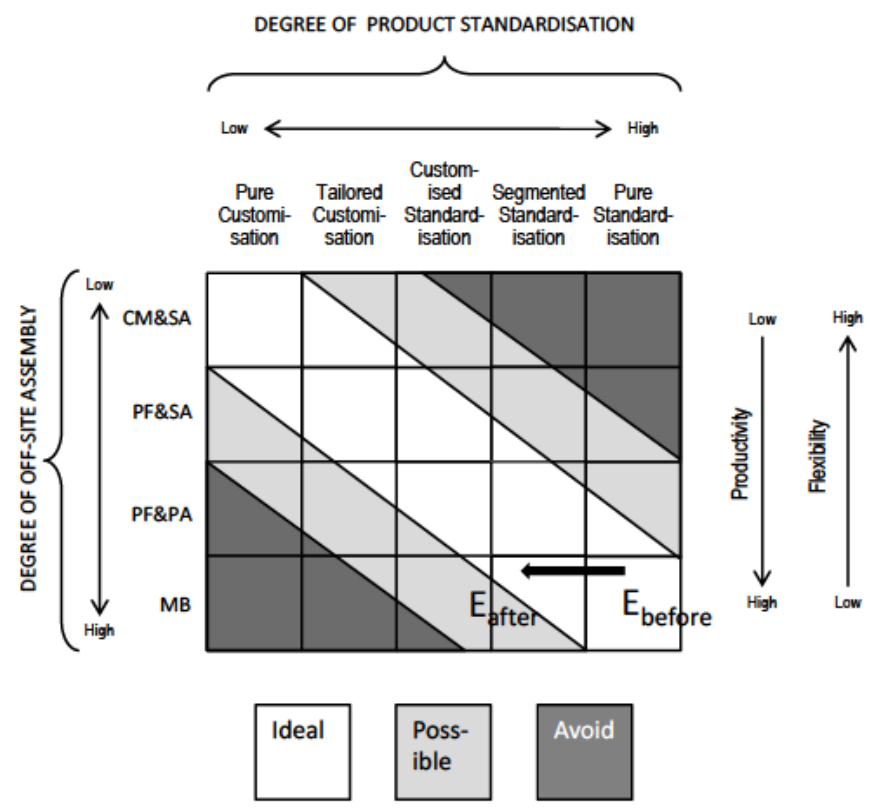

Figure $26 \mathrm{~A}$ change in the degree of product standardisation

The new position of the production system would then be a mismatch between the current production process and the product characteristics. This is useful information and shows that the suggested change come with a risk, visualised by the mismatch in the classification matrix (Figure 26). However if they manage to increase the product flexibility and maintain a production process with a high degree of off-site production it would be a competitive advantage in line with the discussion about Production system D in chapter 7.1.3 above. Another way of handling an increase in product customisation is by decreasing the degree of off-site assembly meaning that they not only move to the left in the classification matrix but also up and thereby find a new position in the matrix where there is a match between product and process characteristics.

\subsection{Reflections and further research}

In this chapter the research is discussed from a more subjective point of view. What was done and how was it done? What could have been done differently and better? Based on these reflections of the research process suggestions for further research are presented.

The initial idea for this research project was to develop a more comprehensive production strategy framework adapted to the house-building industry. The model for this was Miltenburg's (2005) framework for production strategy and the plan was to use the first half of the research project to adapt the framework to a house-building context using existing literature, see the production strategy part of Figure 27. The second half of the research project was supposed to focus on developing a logistics strategy framework linking production strategy to different logistics systems, see the right part of Figure 27. A tentative design of such a framework was sketched up in the beginning of this research project (Figure 27). 


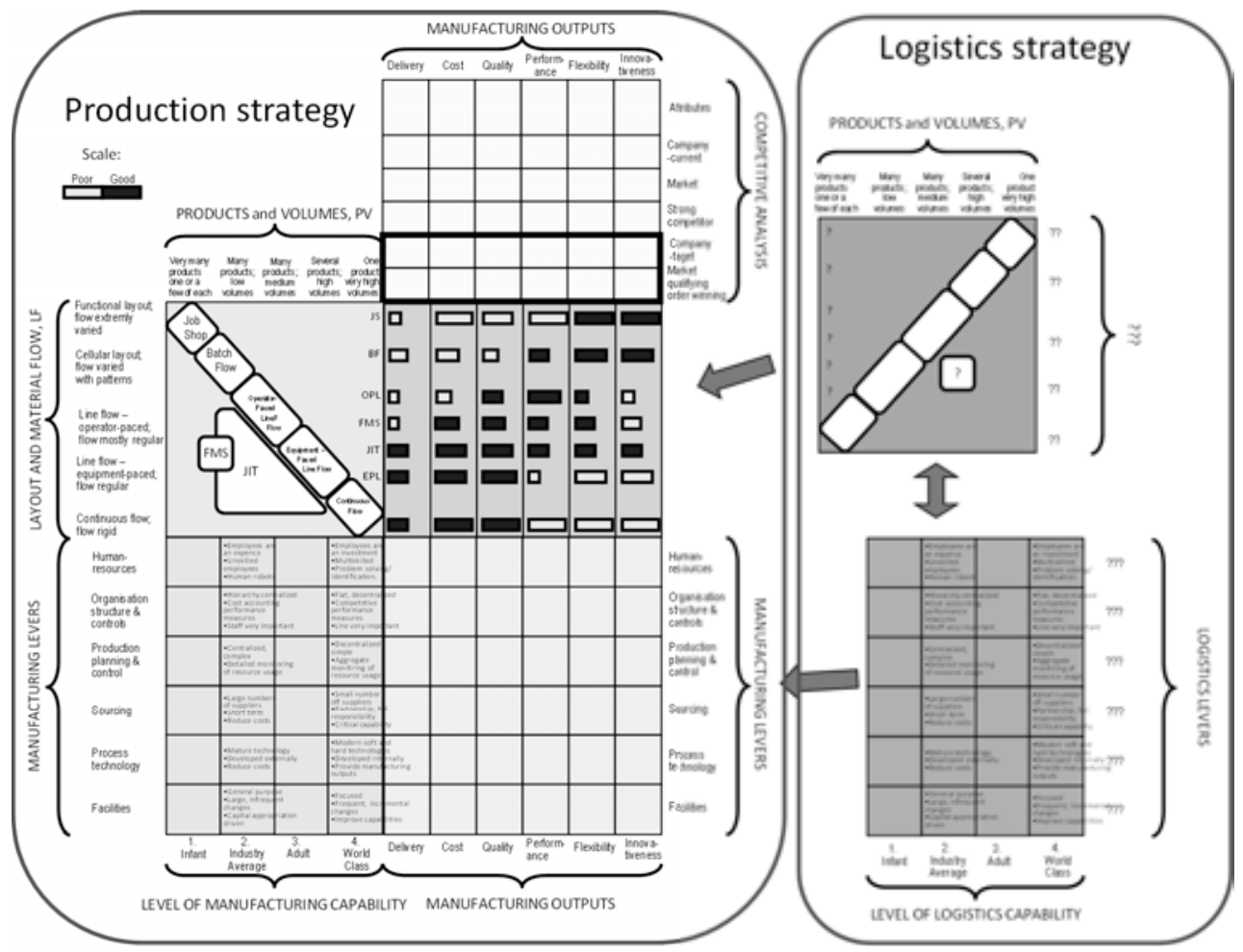

Figure 27 Tentative framework for production and logistics strategy in house-building

However, adapting the production strategy part of the tentative framework (Figure 27) to a house-building context took more time and effort than expected. Hence, instead of developing the whole framework, selected parts of the production strategy framework, e.g. process choice, performance measurement, information exchange, and the production strategy process were studied.

From the initial plan for this research project (Figure 27) some parts have been left for further research. This thesis consider the process choice but other decision categories (Table 10) should be researched and, if necessary, adapted to a house-building context. Tentative research questions concerning this could be: What decision categories are relevant and have to be considered when designing a production system in a house-building context? Are there other decision categories that have to be taken into consideration in the house-building industry, than the ones derived from traditional production strategy literature? Maybe the areas that should be considered in industrialised house-building presented by Lessing (2006), see Table 2, can be seen as decision categories that are useful in a house-building context? If further research and literature on the subject could be synthesised and presented in a structured production strategy framework it would be useful both for academics and practitioners.

The next suggestion for further research is to relate production strategy to logistics and supply chain management. Can different types of production systems be related to different types of logistics systems designed to suit the characteristics of each specific production system? 
Tentative research questions related to this could be: Is there different logistics systems that are used in the house-building industry today? What are the characteristics of the different logistics systems, e.g. strengths and weaknesses? Can the different logistics systems be matched with different production systems for house-building to suit the characteristics of each specific production system? The logistics dimension could be integrated as one part of the production strategy framework, as suggested in Figure 27.

Even though a lot of work has been put down in developing the KPIs for performance measurement, presented in Paper 3 (Jonsson and Rudberg, 2017), and that they have been validated by industry experts representing different production systems, there are issues with some of the KPIs. The main concern is the flexibility KPIs. Some of the industry expert found the KPI for mix flexibility difficult to understand. The KPI for mix flexibility can also be misleading since the range of different products offered by the production system is not taken into consideration as long as more than one type of product is produced. Another issue that can be misleading with the KPIs for delivery and cost dependability is the use of budgeted cost and planned production time. The calculated budget and time plan can be affected by client and market considerations. The way the budgeting is done can affect the KPI even though this is out of the control of the production system. To get as accurate calculations as possible these KPIs should preferably use the production budget and production time plan in the calculations since they are not affected by strategic considerations to the same extent as for example a tender calculation.

When it comes to performance measurement the initial plan was to position a number of production systems in the classification matrix and then use an existing performance measurement system to evaluate how the position in the matrix affected the production systems' ability to perform, using quantitative data. Qualitative estimations indicate that there is a trade-off between productivity related outputs and flexibility, but no research, to my knowledge, has evaluated this using quantitative data. This initial plan had to be left for further research since no structured way of measuring performance, at a production strategy level, could be found in existing literature. The KPIs presented in this research can be used for this purpose and a tentative research question related to this could be: How does the characteristics of the production system affect the ability to perform in different areas of competition? This could help house-building companies to design a production system that is aligned with the targeted market or find a market that is suitable for the production system in use. [AF1][HJ2]

The results of Study 2, taking a production strategy perspective on information exchange, are based on a small sample of production systems. This can be seen as a pre study resulting in the two propositions, i.e. that production systems using some degree of off-site assembly have less complex and less fragmented supply chains, and that they use ICT-tools to a larger extent. This have to be validated using a larger number of production systems and also collecting empirical data from other actors in the supply chain than main contractors, e.g. suppliers, sub-contractors and clients. This is left to further research but the design of this study and the results presented can be used as a starting point for a more comprehensive study regarding a production strategy perspective on how the process choice affects information exchange in a house-building context. 



\section{Contribution}

In this final chapter the contributions of this research are accounted for. To do this the identified gaps, motivating the purpose and research questions, are linked to the results.

The main scientific contribution is made to the production strategy body of knowledge. The research investigates, the relatively unexplored, project based production strategy (see Figure 28), by using the house-building context as a source of empirical data and literature in combination with more traditional production strategy literature.

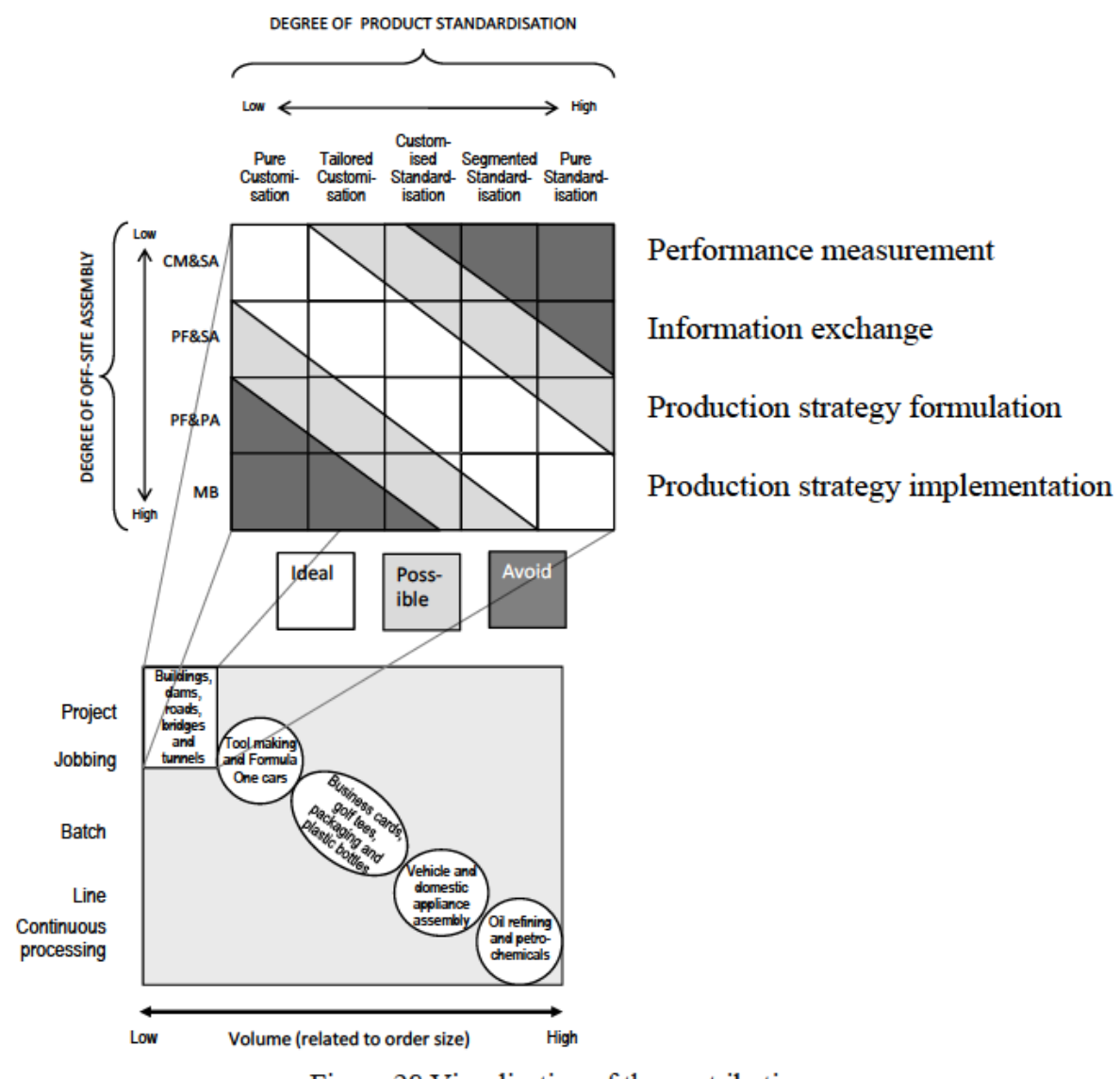

Figure 28 Visualisation of the contribution

Project based production systems are often omitted in production strategy literature (see e.g. Miltenburg, 2005) or treated as one type of production system (see e.g. Hill and Hill, 2009, 
Slack and Lewis, 2011). This simplified view of production strategy in project based manufacturing do not appreciate that different types of production systems for house-building (see e.g. Gibb, 2001, Gibb and Isack, 2003) have strengths and weaknesses in different areas of competition (see e.g. Arif and Egbu, 2010, Barlow et al., 2003, Halman et al., 2008, Pan et al., 2007). The gap identified here is a production strategy perspective on house-building to visualise the link between market requirements and the ability of different types of housebuilding production systems to perform.

The classification matrix (Figure 17) contribute with a structured way of classifying different house-building production systems. The matrix can be used in the same way that the productprocess matrix (Hayes and Wheelwright, 1979) has been used to aligning the process and product characteristics for traditional production industries. Previous literature that tries to categorise production systems for house-building (see e.g. Barlow et al., 2003, Gibb and Isack, 2003, Segerstedt and Olofsson, 2010, Winch, 2003, Voordijk et al., 2006) do not explicitly address the link between production system design and customer requirements in terms of manufacturing outputs. This research illustrate differences in product and process characteristics between different production systems and their relative strengths and weaknesses in different areas of competition. This clarifies how different types of production systems can be competitive as long as there is a match between the requirements from the targeted market and the capabilities of the production system.

The research also makes a contribution by identifying which manufacturing outputs that are important to measure in a house-building context, i.e. quality, delivery, cost and flexibility, and presenting quantitative KPIs that can be used to measure performance, at a production strategy level. There is a lack of well-defined quantitative KPIs for measuring performance at a production strategy level. Most measurements in previous literature are based on qualitative estimations (see e.g. Arif and Egbu, 2010, Blismas et al., 2006, Gibb, 2001, Halman et al., 2008) and the quantitative KPIs found in literature are developed for measuring performance on a more operational level. The quantitative KPIs (Table 21) in combination with the classification matrix (Figure 17) can be a useful tool, to link the process choice to performance in a house-building context, when working with production strategy in house-building both in practice and academia.

Information exchange in a house-building context is not new and considered in previous research. However, previous research study information exchange in either a in traditional house-building context (see e.g. Dainty et al., 2006, Senaratne and Ruwanpura, 2016) or in an industrialised house-building context (see e.g. Bergström and Stehn, 2005, Persson et al., 2009). What is missing, and the contribution here, is a production strategy perspective, using a contingency perspective to look at differences in the approach to information exchange, between different types of production systems. In this research empirically derived propositions of how the process choice affects information exchange in a house-building context are presented.

Finally, this research makes a contribution to the production strategy process literature by studying a production strategy process for an industrialised house-builder. This type of 
empirical research on the production strategy process, i.e. production strategy formulation and implementation, is lacking in production strategy literature (Chatha and Butt, 2015, Dangayach and Deshmukh, 2001), and could not be found in literature concerning industrialised housebuilding either. The contribution here is an extension of production strategy process theory by: (1) Presenting a suggested production strategy process (Figure 20), and (2) identifying context specific challenges that have to be considered when formulating and implementing a production strategy in an industrialised house-building context. The research also presents an analytical framework providing a structure for the formulation and implementation process in a house-building context. This is useful for industrialised house-builders facing a change in production strategy and increases the likelihood of the intended strategy becoming the realised strategy.

The results of this research and the answers to the research questions in chapter 6 , the discussion and managerial implications in chapter 7.1, and the scientific contribution presented above all contributes to fulfilling the purpose:

To extend the production strategy body of knowledge concerning project based production, in the context of house-building. 



\section{References}

Al-Reshaid, K., Kartam, N., Tewari, N. and Al-Bader, H. (2005). A Project Control Process in Pre-Construction Phases: Focus on Effective Methodology. Engineering, Construction and Architectural Management, 12:4, 351-372.

Arif, M. and Egbu, C. (2010). Making a Case for Offsite Construction in China. Engineering, Construction and Architectural Management, 17:6, 536-548.

Azman, M. N. A., Ahamad, M. S. S., Majid, T. A. and Hanafi, M. H. (2010). The Common Approach in Off-Site Construction Industry. Australian Journal of Basic and Applied Sciences, 4:9, 4478 - 4482.

Barlow, J., Childerhouse, P., Gann, D., Hong-Minh, S., Naim, M. and Ozaki, R. (2003). Choice and Delivery in Housebuilding- Lessons from Japan for Uk Housebuilders. Building Research \& Information, 31:2, 134-145.

Barlow, J. and Ozaki, R. (2005). Building Mass Customised Housing through Innovation in the Production System: Lessons from Japan. Environment and Planning A, 37:1, 9-20.

Bassioni, H. A., Price, A. D. F. and Hassan, T. M. (2004). Performance Measurement in Construction. Journal of Management in Engineering, 20:2, 42 - 50.

Beatham, S., Anumba, C., Thorpe, T. and Hedges, I. (2004). Kpis: A Critical Appraisal of Their Use in Construction. Benchmarking: An International Journal, 11:1, 93-117.

Bergström, M. and Stehn, L. (2005). Matching Industrialised Timber Frame Housing Needs and Enterprise Resource Planning: A Change Process. International Journal of Production Economics, 97:2, 172-184.

Bititci, U. S., Carrie, A. S. and Mcdevitt, L. (1997). Integrated Performance Measurement Systems: An Audit and Development Guide. The TQM Magazine, 9:1, 46 - 53.

Blismas, N., Pasquire, C. and Gibb, A. (2006). Benefit Evaluation for Off-Site Production in Construction. Construction Management and Economics, 24:2, 121-130.

Boverket (2012). Bostadsbristen Ur Ett Marknadsperspektiv [the Housing Shortage from a Marketing Perspective]. Karlskrona.

Boverket (2016). Reviderad Prognos Över Behovet Av Nya Bostäder Till 2025 [Uppdated Forecast of the Need for New Accomodation by 2025]. Boverket.

Brege, S., Stehn, L. and Nord, T. (2014). Business Models in Industrialized Building of Multi-Storey Houses. Construction Management and Economics, 32:1-2, 208-226.

Buffa, E. S. (1984). Meeting the Competitive Challenge: Manufacturing Strategy for U.S. Companies, Dow Jones-Irwin.

Byggindustrier, S. (2017). Fler Bostäder Kräver Fler Som Bygger [Increased House-Building Requires More House-Buidlers].

Cbpp, C. B. P. P. (2002). Key Perfomance Indicators.

Chatha, K. A. and Butt, I. (2015). Themes of Study in Manufacturing Strategy Literature. International Journal of Operations \& Production Management, 35:4, 604-698.

Chen, Y., Okudan, G. E. and Riley, D. R. (2010). Sustainable Performance Criteria for Construction Method Selection in Concrete Buildings. Automation in Construction, 19:2, 235-244.

Cohen, M. D., March, J. G. and Olsen, J. P. (1972). A Garbage Can Model of Organizational Choice. Administrative Science Quarterly, 17:1, 1-25.

Cooper, R., Kagioglou, M., Aouad, G., Hinks, J., Sexton, M. and Sheath, D. (1998). The Development of a Generic Design and Construction Process. In: European Conference, Product Data Technology (PDT) Days, 1998. 1-10. 
Cox, A., Ireland, P., Lonsdale, C., Sanderson, J. and Watson, G. (2003). Supply Chains, Markets and Power: Managing Buyer and Supplier Power Regimes, Taylor \& Francis.

Cox, J. F. and Blackstone, J. H. (1998). Apics Dictionary, APICS (Falls Church, VA).

Dainty, A., Moore, D. and Murray, M. (2006). Communication in Construction Theory and Practice, Taylor \& Francis.

Dangayach, G. S. and Deshmukh, S. G. (2001). Manufacturing Strategy - Literature Review and Some Issues. International Journal of Operations \& Production Management, 21:7, $884-932$.

Dehlin, S. and Olofsson, T. (2008). An Evaluation Model for Ict Investments in Construction Projects. Journal of Information Technology in Construction, 13:Case studies of BIM use, 343-361.

Dent, R. J. and Storey, D. A. (2004). Benchmarking the Performance of Design Activities in Construction. London.

Dicicco-Bloom, B. and Crabtree, B. F. (2006). The Qualitative Research Interview. Medical Education, 40:4, 314-321.

Doran, D. and Giannakis, M. (2011). An Examination of a Modular Supply Chain: A Construction Sector Perspective. Supply Chain Management: An International Journal, 16:4, 260-270.

Dubois, A. and Gadde, L.-E. (2002). The Construction Industry as a Loosely Coupled System: Implications for Productivity and Innovation. Construction Management and Economics, 20:7, 621-631.

EFQM (2017). The Efqm Excelence Model [Online]. Available: http://www.efqm.org/theefqm-excellence-model [Accessed 2017-09-03 2017].

Egan, J. (1998). Rethinking Construction. London.

Eisenhardt, K. M. (1989). Building Theories from Case Study Research. Academy of Management Review, 14:4, 532-550.

Erikshammar, J. (2013). Characteristics of Supply Chain Management in Systems Building and Implications for Small Business. Nordic Conference on Construction Economics and Organization : 12/06/2013 - 14/06/2013. Trondheim: Tapir Akademisk Forlag.

Fahey, L. and Christensen, H. K. (1986). Evaluating the Research on Strategy Content. Journal of Management, 12:2, 167-183.

Ferdows, K. and Meyer, A. D. (1990). Lasting Improvements in Manufacturing Performance: In Search of a New Theory. Journal of Operations Management, 9:2, 168 - 184.

Fiala, P. (2005). Information Sharing in Supply Chains. Omega, 33:5, 419-423.

Fine, C. H. and Hax, A. C. (1985). Manufacturing Strategy: A Methodology and an Illustration. Interfaces, 15:6, 28-46.

Flynn, B. B., Sakakibara, S., Schroeder, R. G., Bates, K. A. and Flynn, E. J. (1990). Empirical Research Methods in Operations Management. Journal of Operations Management, 9:2, 250-284.

Gann, D. M. (1996). Construction as a Manufacturing Process? Similarities and Differences between Industrialized Housing and Car Production in Japan. Construction Management and Economics, 14:5, 437-450.

Gibb, A. G. F. (2001). Standardization and Pre-Assembly- Distinguishing Myth from Reality Using Case Study Research. Construction Management and Economics, 19:3, 307315 .

Gibb, A. G. F. and Isack, F. (2003). Re-Engineering through Pre-Assembly - Client Expectations and Drivers. Building Research \& Information, 31:2, 146 - 160.

Golafshani, N. (2003). Understanding Reliability and Validity in Qualitative Research. The qualitative report, 8:4, 597-606. 
Grosskopf, K. R., Elliott, J. W. and Killingsworth, J. E. 2017. Offsite Construction?U.S. Market Trends in Prefabrication. Challenges for Technology Innovation: An Agenda for the Future. CRC Press.

Halldorsson, A. and Aastrup, J. (2003). Quality Criteria for Qualitative Inquiries in Logistics. Journal of Operational Research, 144:2, 321-332.

Hallgren, M., Olhager, J. and Schroeder, R. G. (2011). A Hybrid Model of Competitive Capabilities. International Journal of Operations \& Production Management, 31:5, 511-526.

Halman, J. I. M., Voordijk, J. T. and Reymen, I. M. M. J. (2008). Modular Approaches in Dutch House Building: An Exploratory Survey. Housing Studies, 23:5, 781-799.

Hayes, R. H. and Wheelwright, S. C. (1979). Link Manufacturing Process and Product Life Cycles: Focusing on the Process Gives a New Dimesion to Strategy. Harvard Business Review, 57:1, 133-140.

Hayes, R. H. and Wheelwright, S. C. (1984). Restoring Our Competitive Edge Competing through Manufacturing, John Wiley \& Sons, Inc.

Hill, A. and Hill, T. (2009). Manufacturing Operations Strategy, Palgrave Macmillan.

Hobday, M. (2000). The Project-Based Organisation: An Ideal Form for Managing Complex Products and Systems? Research Policy, 29:7-8, 871-893.

Hong-Minh, S. M., Barker, R. and Naim, M. M. (2001). Identifying Supply Chain Solutions in the Uk House Building Sector. European Journal of Purchasing \& Supply Management, 7:1, 49-59.

Jaillon, L. and Poon, C. S. (2008). Sustainable Construction Aspects of Using Prefabrication in Dense Urban Environment: A Hong Kong Case Study. Construction Management and Economics, 26:9, 953-966.

Jin, G. and Thomson, V. (2003). A New Framework for Mrp Systems to Be Effective in Engineered-to-Order Environments. Robotics and Computer-Integrated Manufacturing, 19:6, 533-541.

Jonsson, H. and Fredriksson, A. (2017). Production Strategy Process: Formulation and Implementation in an Industrialised House-Building Context.

Jonsson, H. and Gosling, J. (2017). Information Exchange in House-Building: A Production Strategy Perspective.

Jonsson, H. and Rudberg, M. (2014). Classification of Production Systems for Industrialized Building: A Production Strategy Perspective. Construction Management and Economics, 32:1-2, 53-69.

Jonsson, H. and Rudberg, M. (2015). Production System Classification Matrix: Matching Product Standardization and Production-System Design. Journal of Construction Engineering and Management, 141:6.

Jonsson, H. and Rudberg, M. (2017). Kpis for Measuring Performance of Production Systems for Residential Building: A Production Strategy Perspective. Construction Innovation, $17: 3,381-403$.

Kadir, M. R. A., Lee, W. P., Jaafar, M. S., Sapuan, S. M. and Ali, A. a. A. (2006). Construction Performance Comparison between Conventional and Industrialised Building Systems in Malaysia. Structural Survey, 24:5, 412-424.

Kagioglou, M., Cooper, R. and Aouad, G. (2001). Performance Management in Construction: A Conceptual Framework. Construction Management and Economics, 19:1, 85-95.

Kamar, K. a. M., Hamid, Z. A., Azman, M. N. A. and Ahamad, M. S. S. (2011). Industrialized Building System (Ibs): Revisiting Issues of Definition and Classification. International Journal of Emerging Sciences 1:2, 120-132.

Kaplan, R. S. and Norton, D. P. (1992). The Balanced Scorecard - Measures That Drive Performance. Harvard Business Review, 70:1, 71 - 79. 
Karlsson, C. (2009). Researching Operations Management, New York, Routledge.

Kasunic, M. (2004). Conducting Effective Pilot Studies. Softwere Engineering Process Group (SEPG) conference. Orlando, Florida.

Kembro, J., Selviaridis, K. and Näslund, D. (2014). Theoretical Perspectives on Information Sharing in Supply Chains: A Systematic Literature Review and Conceptual Framework. Supply Chain Management: An International Journal, 19:5/6, 609-625.

Klinger, M. and Susong, M. B. (2006). The Construciton Project: Phases, People, Terms, Paperwork, Processes ABA Book Publishing.

Kovács, G. and Spens, K. M. (2005). Abductive Reasoning in Logistics Research. International Journal of Physical Distribution \& Logistics Management, 35:2, 132 144.

Lampel, J. and Mintzberg, H. (1996). Customizing Customization. Sloan Management Review, 38:1, 21 - 30.

Landin, A. and Oberg, M. (2014). Productivity and Efficiency in the Development of the Swedish Construction Sector. American Journal of Industrial and Business Management, 2014.

Larsson, J., Eriksson, P. E., Olofsson, T. and Simonsson, P. (2013). Industrialized Construction in the Swedish Infrastructure Sector: Core Elements and Barriers. Construction Management and Economics, 1-14.

Leong, G., Snyder, D. and Ward, P. (1990). Research in the Process and Content of Manufacturing Strategy. Omega International Journal of Management Science, 18:2, $109-122$.

Lessing, J. (2006). Industrialised House-Building: Concept and Processes. Licentiate, Lund University.

Lessing, J., Stehn, L. and Ekholm, A. (2015). Industrialised House-Building - Development and Conceptual Orientation of the Field. Construction Innovation, 15:3, 378-399.

Lidelöw, H., Stehn, L., Lessing, J. and Engström, D. (2015). Industriellt Husbyggande, Studentlitteratur.

Lincoln, Y. S. and Guba, E. G. (1985). Naturalistic Inquiry, Sage.

Lind, H. and Song, H.-S. (2012). Dålig Produktivitetsutveckling I Byggindustrin - Ett Faktum Eller Ett Mätfel [Bad Productivity Growth in the Construction Industry - a Fact or a Measurement Error]. In: Byggindustrier, S. (ed.). Stockholm.

Lorange, P. (1980). Corporate Planning: An Executive Viewpoint, Englewood Cliffs : Prentice-Hall.

Mabert, V. A., Soni, A. and Venkataramanan, M. A. (2003). The Impact of Organization Size on Enterprise Resource Planning (Erp) Implementations in the Us Manufacturing Sector. Omega, 31:3, 235-246.

Marucheck, A., Pannesi, R. and Anderson, C. (1990). An Exploratory Study of the Manufacturing Strategy Process in Practice. Journal of Operations Management, 9:1, 101-123.

Meiling, J., Backlund, F. and Johnsson, H. (2012). Managing for Continuous Improvement in Off-Site Construction: Evaluation of Lean Management Principles. Engineering, Construction and Architectural Management, 19:2, 141-158.

Mesly, O. (2017). Project Feasibility: Tools for Uncovering Points of Vulnerability, CRC Press.

Mills, J., Platts, K. and Gregory, M. (1995). A Framework for the Design of Manufacturing Strategy Processes: A Contingency Approach. International Journal of Operations \& Production Management, 15:4, 17-49.

Miltenburg, J. (2005). Manufacturing Strategy - How to Formulate and Implement a Winning Plan, New York, Productivity Press. 
Mintzberg, H., Raisinghani, D., Th, Xe, Or, Xea and T, A. (1976). The Structure of "Unstructured" Decision Processes. Administrative Science Quarterly, 21:2, 246-275.

Mintzberg, H. and Waters, J. A. (1985). Of Strategies, Deliberate and Emergent. Strategic management journal, 6:3, 257-272.

Mirzaei, N. E. (2015). Involving Individuals in the Manufacturing Strategy Formation: Strategic Consensus among Workers and Managers. Doctor of Philosophy, Chalmers University of Thechnology.

Pan, W., Gibb, A. G. F. and Dainty, A. R. J. (2007). Perspectives of Uk Housebuilders on the Use of Offsite Modern Methods of Construction. Construction Management and Economics, 25:2, 183-194.

Pan, W., Gibb, A. G. F. and Dainty, A. R. J. (2008). Leading Uk Housebuilders' Utilization of Offsite Construction Methods. Building Research \& Information, 36:1, 56-67.

Pan, W., Gibb, A. G. F. and Dainty, A. R. J. (2012). Strategies for Integrating the Use of OffSite Production Technologies in House Building. Journal of Construction Engineering and Management, 138:11, 1331-1340.

Persson, S., Malmgren, L. and Johnsson, H. (2009). Information Management in Industrial House Design and Manufacture. Journal of information Technology in Construciton, $14,110-122$.

Platts, K. W. and Gregory, M. J. (1990). Manufacturing Audit in the Process of Strategy Formulation. International Journal of Operations \& Production Management, 10:9, 5-26.

Platts, K. W., Mills, J. F., Neely, A. D., Gregory, M. J. and Richards, A. H. (1996). Evaluating Manufacturing Strategy Formulation Processess. International Journal of Production Economics, 46, 233-240.

Raynsford, N. (2000). Kpi Report for the Minister for Construction. Norwich.

Riley, M. and Cotgrave, A. (2013). Construction Technology 1: House Construction, Palgrave macmillan.

Robinson, H. S., Anumba, C. J., Carrillo, P. M. and Al-Ghassani, A. M. (2005). Business Performance Measurement Practices in Construction Engineering Organisations. Measuring Business Excellence, 9:1, 13-22.

Rodney Turner, J. (2005). The Role of Pilot Studies in Reducing Risk on Projects and Programmes. International Journal of Project Management, 23:1, 1-6.

Rudberg, M. (2002). Manufacturing Strategy: Linking Competitive Priorities, Decision Categories and Manufacturing Networks. PhD thesis, Linköping University.

Rudberg, M. (2004). Linking Competitive Priorities and Manufacturing Networks: A Manufacturing Strategy Perspective. International Journal of Manufacturing Technology and Management, 6:1/2, 55-80.

Safizadeh, M. H., Ritzman, L. P. and Mallick, D. (2000). Revisiting Alterantive Theorethical Paradigms in Manufacturing Strategy. Production and Operations Management, 9:2, $111-126$.

Statistics Sweden. (2017). Påbörjade Nybyggda Bostadslägenheter [Online]. http://www.scb.se/en/finding-statistics/statistics-by-subject-area/housingconstruction-and-building/housing-construction-and-conversion/new-construction-ofresidential-buildings/pong/tables-and-graphs/number-of-started-dwellings-under-newconstruction/: [Accessed 2017-04-25 2017].

Statistics Sweden, Construction, Rents and Real Estate unit. (2017). Number of Completed Dwellings in New Construction Increasing [Online]. Available:

http://www.scb.se/en/finding-statistics/statistics-by-subject-area/housingconstruction-and-building/housing-construction-and-conversion/new-construction-ofresidential-buildings/pong/statistical-news/completed-new-construction-conversion- 
and-demolition-of-multi-dwelling-buildings-2016---definitive-figures/ [Accessed 2017-09-03 2017].

Schmenner, R. W. and Swink, M. L. (1998). On Theory in Operations Management. Journal of Operations Management, 17:1, 97-113.

Schoenwitz, M., Potter, A., Gosling, J. and Naim, M. (2017). Product, Process and Customer Preference Alignment in Prefabricated House Building. International Journal of Production Economics, 183, Part A, 79-90.

Segerstedt, A. and Olofsson, T. (2010). Supply Chains in the Construction Industry. Supply Chain Management: An International Journal, 15:5, 347-353.

Senaratne, S. and Ruwanpura, M. (2016). Communication in Construction: A Management Perspective through Case Studies in Sri Lanka. Architectural Engineering and Design Management, 12:1, 3-18.

Sethi, A. K. and Sethi, S. P. (1990). Flexibility in Manufacturing: A Survey. The International Journal of Flexible Manufacturing Systems, 2, 289 - 328.

Skinner, W. (1969). Manufacturing - Missing Link in Corporate Strategy. Harvard Business Review, May-June, 136-145.

Slack, N. and Lewis, M. (2011). Operations Strategy, Harlow, Pearson Education Limeted.

Stenbacka, C. (2001). Qualitative Research Requires Quality Concepts of Its Own. Management Decision, 39:7, 551-556.

Stuart, I., Mccutcheon, D., Handfield, R., Mclachlin, R. and Samson, D. (2002). Effective Case Research in Operations Management: A Process Perspective. Journal of Operations Management, 20:5, 419-433.

Swamidass, P. M. and Newell, W. T. (1987). Manufacturing Strategy, Environmental Uncertainty and Performance: A Path Analytic Model. Management Science, 33:4, 509-524.

Swan, W. and Kyng, E. (2004). An Introduction to Key Performance Indicators. Manchester: Centre for Construction Innovation.

Szulanski, G. (2000). The Process of Knowledge Transfer: A Diachronic Analysis of Stickiness. Organizational Behavior and Human Decision Processes, 82:1, 9-27.

Titus, S. and Bröchner, J. (2005). Managing Information Flow in Construction Supply Chains. Construction Innovation, 5:2, 71-82.

Van De Ven, A. H. (1992). Suggestions for Studying Strategy Process: A Research Note. Strategic Management Journal, 13:S1, 169-188.

Wang, Y., Potter, A. and Naim, M. (2007). Electronic Marketplaces for Tailored Logistics. Industrial Management \& Data Systems, 107:8, 1170-1187.

Ward, P. T., Mccreery, J. K., Ritzman, L. P. and Sharma, D. (1998). Competitive Priorities in Operations Management. Decision Science, 29:4, 1035 - 1046.

Whitley, R. (2006). Project-Based Firms: New Organizational Form or Variations on a Theme? Industrial and Corporate Change, 15:1, 77-99.

Winch, G. (2003). Models of Manufacturing and the Construction Process: The Genesis of Re-Engineering Construction. Building Research \& Information, 31:2, 107-118.

Voordijk, H., Meijboom, B. and Haan, J. D. (2006). Modularity in Supply Chains: A Multiple Case Study in the Construction Industry. International Journal of Operations \& Production Management, 26:6, 600-618.

Voss, C., Tsikriktsis, N. and Frohlich, M. (2002). Case Research in Operations Management. International Journal of Operations \& Production Management, 22:2, 195-219.

Yin, R. K. (2009). Case Study Research Design and Methods, Thousand Oaks, Carlifornia Sage Publications.

Yin, R. K. (2013). Case Study Research: Design and Methods, Sage publications. 


\section{Papers}

The papers associated with this thesis have been removed for copyright reasons. For more details about these see:

http:// urn.kb.se/ resolve?urn=urn:nbn:se:liu:diva-143262 